
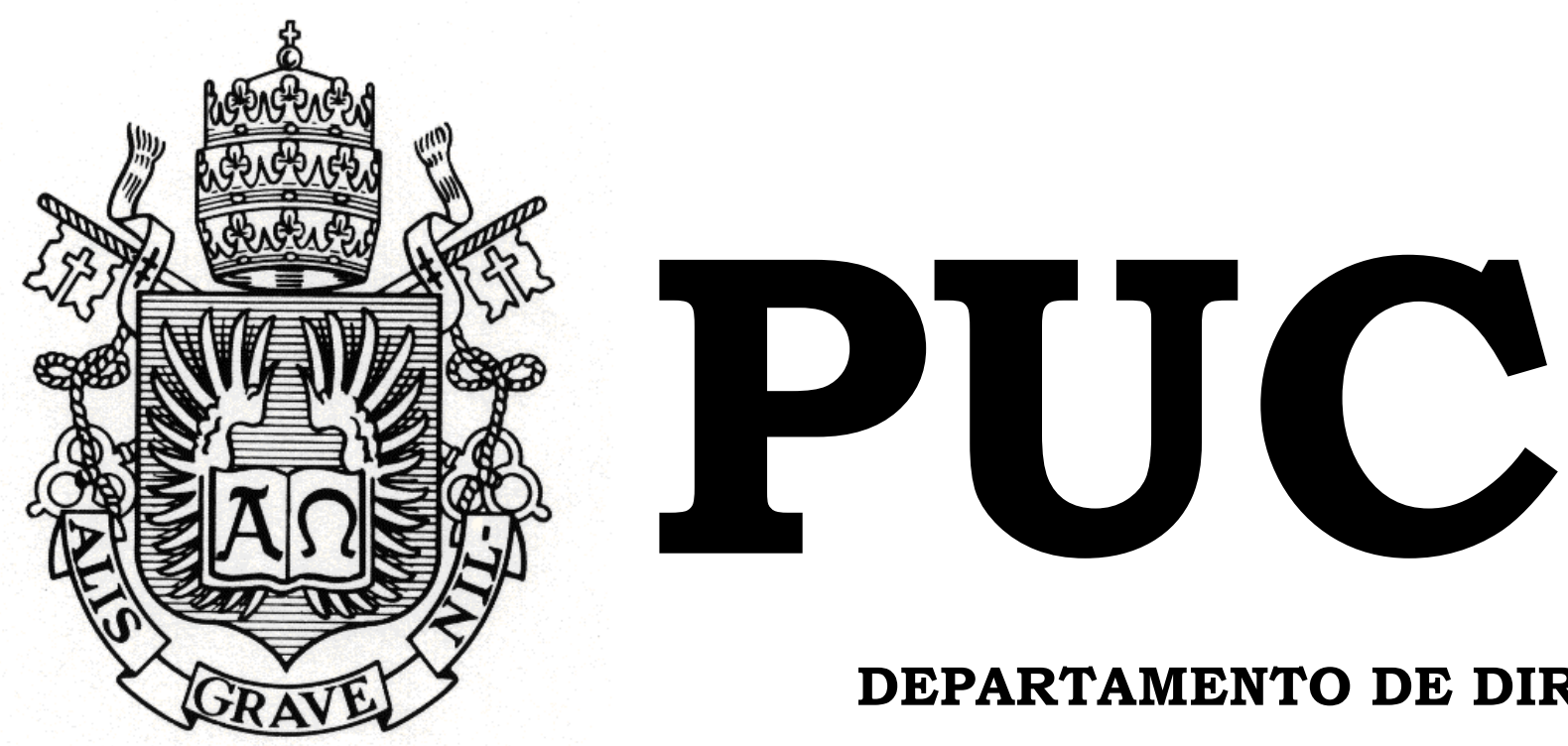

\title{
Liberdade de Expressão e a Proibição dos Jogos Eletrônicos
}

\author{
por \\ VICTOR CAMPOS CLEMENT LEAHY
}

ORIENTADOR: Fábio Carvalho Leite

2010.2

PONTIFÍCIA UNIVERSIDADE CATÓLICA DO RIO DE JANEIRO RUA MARQUÊS DE SÃO VICENTE, 225 - CEP 22453-900 RIO DE JANEIRO - BRASIL 


\title{
Liberdade de Expressão e a Proibição dos Jogos Eletrônicos
}

\author{
por \\ VICTOR CAMPOS CLEMENT LEAHY
}

Monografia apresentada ao

Departamento de Direito da

Pontifícia Universidade Católica do

Rio de Janeiro (PUC-Rio) para a obtenção do Título de Bacharel em Direito.

Orientador: Fábio Carvalho Leite 


\section{DEDICATÓRIA}

Aos meus pais, por serem meus exemplos de vida, a fonte dos meus valores, do meu caráter e da minha disciplina, e meu eterno porto seguro.

Ao meu irmão, pelos anos de convivência, pelas dicas e pela experiência compartilhada.

Aos meus avós, pela ternura e participação fundamental na minha vida.

Por fim, à minha amada Jéssica, pela paciência, pelo carinho, pela dedicação incondicional e, acima de tudo, por sempre acreditar em mim. 


\section{AGRADECIMENTOS}

Primeiramente, agradeço a Deus, não apenas pela família e amigos maravilhosos, mas por Ele ser a figura basilar em todos os sucessos que já obtive na vida.

Em seguida, a todos os meus colegas do grupo de pesquisa e iniciação científica, Clara, Eduarda, Eduardo, Janaína, Valéria e Yannick, pelos debates, encontros e reflexões sobre um tema que se revelou, ao mesmo tempo, fascinante e desafiador para mim.

Do mesmo modo, agradeço ao meu orientador de iniciação científica e monografia, Fábio Carvalho Leite, pelas sábias lições que me foram transmitidas ao longo da faculdade, as quais foram essenciais para o meu amadurecimento acadêmico e para o desenvolvimento do presente trabalho.

Depois, ao suporte da PUC-RIO, com seu patrocínio ao longo desses dois últimos anos, acreditando no potencial dessa linha de pesquisa.

Finalmente, a todos os meus amigos, pelas discussões, críticas e sugestões, que foram essenciais para lapidar meu raciocínio e fortalecer meus argumentos. 


\section{RESUMO}

Os jogos eletrônicos representam um tipo de mídia em nítida ascensão, fomentando uma indústria que movimenta, hoje, mais de US\$ 50 bilhões por ano, em todo mundo. Nada obstante, em que pese a sua popularidade, os jogos ainda sofrem com preconceitos e interpretações equivocadas, sendo usualmente tratados como brinquedos de criança, o que os coloca em uma situação marginalizada frente aos outros tipos de mídia. Nessas condições, não são raras as intervenções do Estado para proibir ou regular o conteúdo de determinados jogos, no intuito de preservar crianças e adolescentes da exposição a cenas com violência, sexo ou drogas.

Dessa forma, o presente trabalho busca demonstrar como tais medidas restritivas partem de premissas equivocadas e ferem sensivelmente a liberdade de expressão, assim como conferem um tratamento injustificado aos jogos eletrônicos. Por fim, será demonstrado como a Classificação Indicativa, auxiliada do poder familiar, mostra-se como uma solução constitucionalmente mais adequada para o problema, uma vez que delimita o conteúdo apropriado para os mais jovens sem, contudo, impedir o acesso por parte do público adulto.

Palavras-chave: LIBERDADE DE EXPRESSÃO; CENSURA;

PROIBIÇÃO; JOGOS ELETRÔNICOS; VIDEOGAMES;

CLASSIFICAÇÃO INDICATIVA. 


\section{ABSTRACT}

Video games represent a media on the rise, supporting an industry that generates more than $\$ 50$ billion per year worldwide. Despite its popularity, video games suffer from prejudices and misconceptions, as they are usually seen as children's toys, which puts them in a marginalized position in relation to other media types. Under these circumstances, it is not rare for countries to prohibit or regulate the content of certain games, in order to protect children and adolescents from exposure to scenes of violence, sex or drugs. This paper will demonstrate how such restrictive measures start from questionable assumptions, which in turn hurt substantially the freedom of expression. Finally, it will be shown how the rating system, with the aid of parental control, proves to be a more appropriate solution to the problem, since it determines the appropriate content for young people without limiting access by adults.

Keywords: FREEDOM OF SPEECH; CENSORSHIP; PROHIBITION; VIDEO GAMES; RATING SYSTEM. 
"For every problem there is a solution that is simples, neat and wrong."

- H.L. Mencken (1880-1956) 


\section{SUMÁRIO}

INTRODUÇÃO

9

CAPÍTULO I - A EMERGÊNCIA DOS JOGOS ELETRÔNICOS ... 12

1.1. A origem dos jogos eletrônicos ......................................................... 12

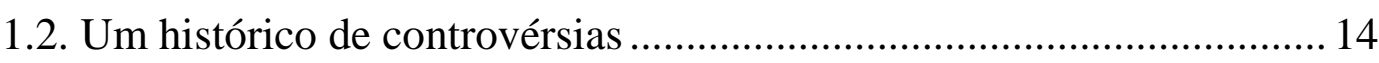

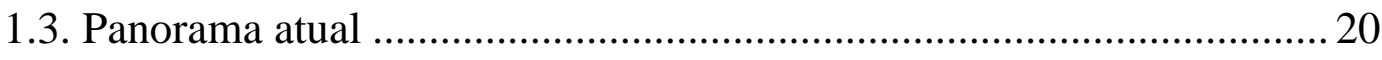

CAPÍTULO II: O CENÁRIO BRASILEIRO ……………….................. 23

2.1. Proibição dos jogos pelo Poder Executivo …………………………...... 23

2.2. Proibição dos jogos pelo Poder Judiciário ............................................ 26

2.2.1. Ação civil pública de $\mathrm{n}^{\circ}$ 1999.38.00.037967-8 ………….......... 27

2.2.2. Ação civil pública de $\mathrm{n}^{\circ}$ 2002.38.00.046529-6 ......................... 29

2.2.3. Ação civil pública de $\mathrm{n}^{\circ}$ 2006.38.00.014197-6 .......................... 31

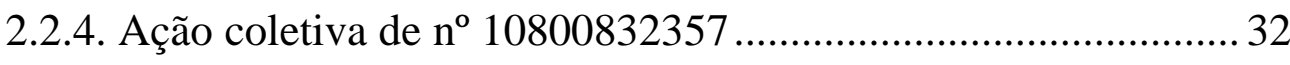

2.3. Proibição dos jogos pelo Poder Legislativo .............................................. 32

CAPÍTULO III: REFLEXÕES SOBRE A PROIBIÇÃO DOS JOGOS

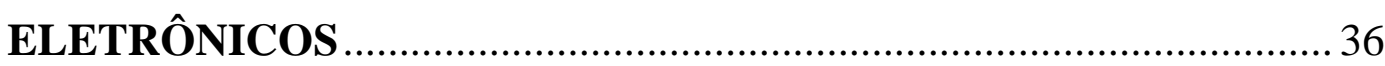

3.1. Desconstruindo premissas equivocadas …………………………........ 36

3.2. Os jogos eletrônicos e os outros tipos de mídia ..................................... 44

3.3. Vícios das medidas proibitivas ............................................................. 50

3.4. Proposições normativas: uma prévia dos precedentes americanos ...... 54

\section{CAPÍTULO IV: O PAPEL DA CLASSIFICAÇÃO INDICATIVA E}

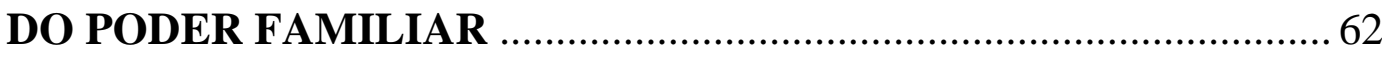

4.1. Classificação Indicativa - conceito e função .......................................... 62

4.2. A função dos pais no controle de conteúdo............................................. 64

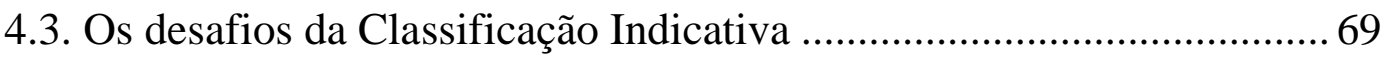

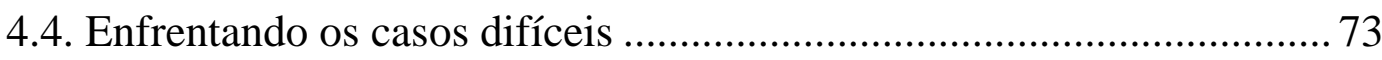




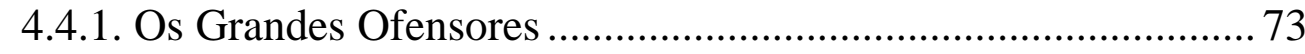

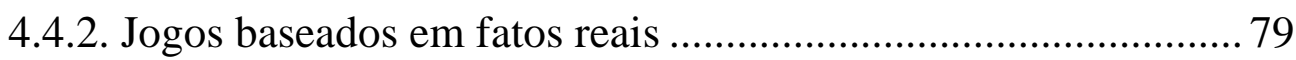

CONCLUSÃO

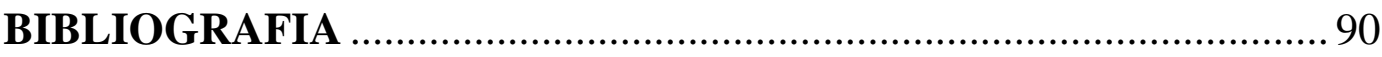




\section{INTRODUÇÃO}

Segundo o artigo $5^{\circ}$, inciso IX, da Constituição Federal, é livre a expressão da atividade intelectual, artística, científica e de comunicação, independentemente de censura ou licença. Seu art. 220, por sua vez, estabelece que a manifestação do pensamento, a criação, a expressão e a informação, sob qualquer forma, processo ou veículo não sofrerão qualquer restrição, enquanto seu $\S 2^{\circ}$ diz ser vedada toda e qualquer censura de natureza política, ideológica e artística. Desse modo, os jogos eletrônicos, por se tratarem de uma forma de expressão da atividade intelectual, ou até mesmo artística ${ }^{1}$, deveriam gozar da mesma garantia fundamental assegurada aos outros tipos de mídia, tais como o cinema ou a televisão. Nada obstante, não é essa a realidade que encontramos no Brasil, considerando que 12 jogos já tiveram sua comercialização proibida em território nacional e diversos projetos de lei encontram-se em tramitação para proibir a venda de jogos violentos. Nessas condições, pergunta-se: Como é possível tamanho antagonismo? Como podemos preservar a liberdade de expressão no universo dos jogos eletrônicos? Existe alguma diferença entre os jogos e as outras mídias que justifique um tratamento diferenciado? Será que deve haver um limite de conteúdo para os jogos eletrônicos? O que se busca preservar com a proibição? Será que essa é a única (ou a melhor) alternativa?

Solucionar esse dilema não é uma tarefa fácil, mas que se mostra fundamental se considerarmos os avanços e conquistas dessa indústria que está redefinindo os conceitos de entretenimento. Como evidência dessa transformação, é possível citar o jogo Call of Duty: Modern Warfare 2, recente lançamento da empresa americana Activision Blizzard, o qual

\footnotetext{
${ }^{1}$ Existem grandes defensores do teor artístico dos jogos eletrônicos, tendo em vista as características que esses partilham com outros tipos de arte. Ainda que eloqüente, tal discussão foge ao escopo do presente trabalho.

Sobre o tema, cf. PROTASIO, Arthur. Games e Liberdade de Expressão. Disponível em <http://direitorio.fgv.br/sites/direitorio.fgv.br/files/Games\%20e\%20Liberdade\%20de\%20Expressã o_Arthur\%20Protasio.pdf>. Acesso em 28 de outubro de 2010.
} 
conseguiu angariar, em apenas 5 dias, 550 milhões de dólares, batendo o recorde da indústria de entretenimento ${ }^{2}$. Ademais, para efeitos de contextualização, vale destacar o impacto que esse segmento da indústria exerce na economia mundial. Segundo dados recentes da DFC Intelligence, empresa de pesquisa de marketing e consultoria americana, a indústria dos jogos eletrônicos apresentou uma receita global de US\$ 60,4 bilhões em 2009, com previsão de crescimento a 70,1 bilhões de dólares em $2015^{3}$. Já quanto ao Brasil, a empresa americana Warner Games projeta que a venda de jogos crescerá $28 \%$ este ano, sendo que, de acordo com as estimativas da International Development Group (IDG), consultoria especializada na área de videogames, o mercado brasileiro movimentou por volta de $\mathrm{R} \$ 500$ milhões entre jogos e consoles no ano passado ${ }^{4}$. Diante de números tão expressivos, fica evidente a relevância do tema, considerando a expansão prevista para o segmento e a forma como tais jogos movimentam o mercado. Em sentido contrário, as intervenções estatais, tal como ocorrem hoje, implicam em um sério obstáculo ao desenvolvimento dessa tecnologia, principalmente quando as decisões são tomadas com pouco conhecimento técnico ou aprofundamento na matéria.

Desse modo, por se tratar de um problema com grande repercussão social, ensejando medidas dos Poderes Executivo, Judiciário e Legislativo, o presente trabalho buscou estudar alternativas, que não a proibição, para conciliar a proteção à formação infanto-juvenil com o direito à liberdade de expressão. Com a finalidade de alcançarmos o objetivo proposto, foram feitos estudos de diversas obras que tratam da relação entre os jogos, violência e liberdade de expressão, bem como foram analisados os dispositivos legais, decisões judiciais e projetos de lei pertinentes ao tema.

\footnotetext{
${ }^{2}$ AURICCHIO, Jocelyn. Game de guerra bate recordes e vira fenômeno da cultura pop. Disponível em <http://www.viuisso.com.br/wp-content/uploads/2009/11/L2.jpg>. Acesso em 28 de outubro de 2010.

${ }^{3}$ INFO - PLANTÃO. Setor de games movimenta US\$ 60 bi por ano. Disponível em <http://info.abril.com.br/noticias/mercado/setor-de-games-movimenta-us-60-bi-por-ano15062010-15.shl>. Acesso em 28 de outubro de 2010.

${ }^{4}$ VALOR ONLINE. Brasil desperta confiança do setor de videogame. Disponível em <http://200.198.118.131/clipping/Arquivo/2010/Mar\%C3\%A7o/24738.pdf>. Acesso em 28 de outubro de 2010.
} 
Cabe ressalvar, contudo, que a produção brasileira sobre o assunto ainda não é abundante, o que justifica a grande quantidade de referências estrangeiras, traduzidas livremente para esse trabalho.

Por conseguinte, será traçado, no capítulo I, um grande panorama sobre a evolução dos jogos eletrônicos, perpassando sua história, principais controvérsias e quadro hodierno. Em seguida, será feita, no capítulo II, a apresentação dos casos brasileiros, os quais incluem as decisões proferidas pela Secretaria de Direito Econômico e pelo Poder Judiciário, bem como os projetos de lei em tramitação no Congresso Nacional. O capítulo III, a seu turno, será o momento da análise crítica da proibição dos jogos eletrônicos, oportunidade em que as premissas equivocadas serão desmistificadas, o contraste com os outros tipos de mídia será realizado, os vícios das medidas proibitivas serão destacados e os precedentes americanos, trazidos à luz. Por fim, restará ao capítulo IV tratar da Classificação Indicativa - solução alternativa às medidas proibitivas - fixando seu conceito, natureza e função, assim como os desafios que a cercam e a sua relação com os casos difíceis. Nesse mesmo contexto, também será demonstrado como o poder-dever da educação familiar é vital para a eficácia do sistema, que se apresenta atualmente como o meio mais adequado a resguardar a liberdade de expressão e a proteção das crianças e adolescentes. 


\section{CAPÍTULO I - A EMERGÊNCIA DOS JOGOS ELETRÔNICOS}

\subsection{A origem dos jogos eletrônicos ${ }^{5}$}

O surgimento dos jogos eletrônicos remonta ao final da década de 40 , quando os primeiros programas ligados a essa tecnologia foram criados. Assim, em 1947, nos Estados Unidos, Thomas T. Goldsmith e Estle Ray Mann patentearam um aparelho denominado Cathod Ray Tube Amusement, o qual se valia de oito tubos de vácuo para simular o disparo de mísseis em alvos, enquanto maçanetas serviam para ajustar a curvatura e a velocidade dos projéteis. Apesar da sua interface elementar, tal equipamento é considerado o primeiro marco na história dos jogos eletrônicos, já que a sua programação serviu de base para o desenvolvimento de jogos mais elaborados nas décadas posteriores.

Posteriormente, no final da década de 50 e avançar dos anos 60, jogos com maior grau de sofisticação e complexidade passaram a ser produzidos. Nesse período, grande parte da criação se deu em ambiente universitário, em função do limitado acesso aos computadores necessários para esse tipo de empreitada. Ademais, o próprio desenvolvimento dos jogos era feito de forma amadora, já que os mesmos eram frutos de simples hobby dos seus idealizadores. Foi dessa forma que, em 1958, o físico americano William Higinbotham criou o jogo Tennis for Two, usando um osciloscópio e um computador analógico, com o intuito de entreter os visitantes do Brookhaven National Laboratory, em Nova Iorque. Há quem defenda ter sido esse o primeiro jogo eletrônico do mundo, mas foi apenas em 1961 que um grupo de estudantes do Massachusetts Institute of Technology criou o jogo Spacewar!, hoje reconhecido por grande parte do

\footnotetext{
${ }^{5}$ Cf. WIKIPEDIA. History of video games. Disponível em 〈http://en.wikipedia.org/wiki/History of_video_games〉. Acesso em 28 de outubro de 2010.
} 
setor como o verdadeiro primogênito, graças ao impacto que teve em seu tempo. ${ }^{6}$

A década de 70, por sua vez, marcou a era de ouro das máquinas de jogos. Em função do rápido progresso tecnológico e do interesse cada vez maior do seu público, os jogos eletrônicos passaram a ter seu potencial econômico explorado através das máquinas públicas de jogos, também conhecidas como arcades. Destarte, o primeiro jogo eletrônico a ser considerado comercialmente viável foi o Computer Space, uma adaptação do jogo Spacewar! lançada em 1971, o qual fixou os alicerces para o aparecimento de uma nova indústria no setor do entretenimento. Com efeito, Pac-man e Asteroids foram outros exemplos de jogos que se popularizam durante essa fase.

Dos anos $70 \mathrm{em}$ diante, diversos saltos tecnológicos marcaram a evolução dos jogos eletrônicos, servindo esses de referência da transição entre gerações. Nessa perspectiva, os jogos eletrônicos se encontram, hoje, em sua $7^{a}$ geração (compreendida a partir de 2004), a qual é caracterizada por um realismo e nível de interação sem precedentes. Em contrapartida, junto com o espantoso avanço tecnológico, cresceu também a preocupação dos pais, políticos, psicólogos e educadores no que concerne ao conteúdo dos jogos eletrônicos. A razão para tanto não poderia ser outra: com o avançar dos anos, os jogos deixaram de ser um simples brinquedo rudimentar para se tornar uma mídia extremamente interativa, atraente, inteligente e com a capacidade de tratar de temas mais maduros - sendo alguns deles não politicamente corretos ou de gosto duvidoso. Apesar disso, não foram precisos episódios violentos, tais como os tiroteios ocorridos em Columbine (1999) e em Virginia Tech (2007), nos EUA, para que os jogos eletrônicos chamassem a atenção da sociedade. Na realidade, eventos como esses apenas serviram (e ainda servem) de estopim para uma reflexão maior: qual é o limite dos jogos eletrônicos?

\footnotetext{
${ }^{6}$ UOL - JOGOS. A História do Videogame. Disponível em $\langle$ http://jogos.uol.com.br/reportagens/historia/1961.jhtm〉. Acesso em 28 de outubro de 2010.
} 


\subsection{Um histórico de controvérsias ${ }^{7}$}

Ao analisarmos o histórico de controvérsias dos jogos eletrônicos, percebemos que as discussões relacionadas aos seus conteúdos se fazem presentes desde a década de 70, período que marcou o início da popularização dos videogames. Assim, foi em 1976 que tivemos o lançamento do primeiro título polêmico da história dos videogames, o qual era intitulado Death Race. Produzido pela empresa americana Exidy, Death Race tratava-se de um jogo de arcade baseado no filme Death Race 2000, de 1975, e tinha como objetivo o atropelamento do maior número possível de "gremlins". Dessa forma, quanto maior fosse o número de mortos, maior seria a quantidade de pontos conquistada pelo jogador. Apesar do seu formato em preto e branco e dos gráficos precários, o simples fato de o jogo retratar a matança despropositada, aliado dos gritos de horrores das vítimas virtuais, fez com que o mesmo fosse duramente criticado pela imprensa e rejeitado pelo público, logo após o seu lançamento. Frente a protestos e a polêmica gerada, a empresa decidiu retirar os exemplares inseridos no mercado, sendo especulado que apenas 500 cópias do jogo haviam sido produzidas até então.

Mais tarde, em 1983, uma nova polêmica surgiu com o jogo Custer's Revenge em função do seu propósito sexista e violento. Nesse exemplar, desenvolvido pela empresa Mystique, o jogador assume o papel de George Armstrong Custer, consagrado general americano, e tem como objetivo desviar de diversas flechas, trajando apenas chapéu e botas, até alcançar uma índia que se encontra amarrada a um tronco, no final do cenário. Caso lograsse êxito, o jogador, então, completava o jogo ao estuprar a vítima, ganhando pontos pela duração da violência. Por motivos óbvios, tal obra incitou a revolta e o protesto de diversos grupos feministas nos EUA, tais como a Women Against Pornography e a National Organization for

\footnotetext{
${ }^{7} \mathrm{Cf}$. GONZALES, Lauren. When two tribes go to war: a history of video game controversy. Disponível em <http://www.gamespot.com/features/6090892/> Acesso em 28 de outubro de 2010.
} 
Women, bem como da American Indian Community House. De toda sorte, apesar da empresa Mystique ter sido conhecida pelos seus lançamentos de conteúdo erótico, fato é que Custer's Revenge não teve tanto sucesso quanto teve de polêmica, uma vez que padecia de fraca jogabilidade e gráficos precários. Ainda assim, é importante ressaltar que a atenção dada pela imprensa teve um reflexo significativo na popularização do título, o qual teve, afinal, 80.000 cópias vendidas, correspondente ao dobro de vendas dos outros jogos adultos da mesma empresa. ${ }^{8}$ Apesar desse número parecer expressivo, se considerarmos que outros jogos do seu tempo estavam começando a vender 500.000 cópias ou mais, fica evidente que Custer's Revenge não foi um grande sucesso, o que demonstra que temas violentos ou apelativos não conseguem, por si só, garantir a viabilidade de um videogame.

Depois de Custer's Revenge, diversos outros jogos vieram a ser alvo de escrutínio público. Entre eles, encontram-se Wolfenstein 3D, que gerou discussão por conta do elevado grau de violência e dos símbolos nazistas apresentados, e Night Trap, que foi objeto de críticas pelas cenas de violências contra as mulheres e pelo tipo de vestimenta das protagonistas, que reforçava seu apelo sexual. Contudo, em que pesem os debates gerados por essas produções, o verdadeiro chamariz de 1992 foi um jogo que glorificava a violência de uma maneira tão explicita que até mesmo simples transeuntes tinham a curiosidade de conhecê-lo. Surgiu, assim, o jogo Mortal Kombat.

Criado pela empresa americana Midway Games, Mortal Kombat originou-se como um jogo de luta para arcade, no qual o objetivo era enfrentar diversos adversários em um torneio mortal. Não fosse a quantidade de sangue o suficiente, o jogo também tinha como característica a possibilidade de assassinar os oponentes de forma brutal. Dessa forma, ao vencer a partida, o jogador ouvia uma voz dizer "Finish him", devendo se

\footnotetext{
${ }^{8}$ KOHLER, Chris. How protests against games cause them to sell more copies. Disponível em <http://www.wired.com/gamelife/2007/10/how-protests-ag/>. Acesso em 28 de outubro de 2010.
} 
valer de uma série de comandos específicos para que, então, pudesse realizar o aclamado "Fatality", o último golpe que fulminaria o adversário com extrema violência. Segundo Jeff Greeson, editor chefe e criador do site The Realm of Mortal Kombat, a explicação para a popularidade do jogo era bastante simples:

Mortal Kombat não só se diferenciava do resto, mas te pegava pelo colarinho e demandava sua atenção. Mortal Kombat tinha os maiores e mais realistas personagens de videogame já criados até então. Você literalmente assistia imagens digitalmente animadas de pessoas voando pelos ares e acabando umas com as outras. ${ }^{9}$

No entanto, foi apenas quando a empresa Acclaim comprou os direitos do jogo e o trouxe para dentro dos lares que a imprensa passou a se preocupar com o assunto. Como era de se esperar, o jogo foi fortemente criticado pelo seu excesso de violência, sendo questionado se esse tipo de mensagem poderia ser veiculado em um brinquedo essencialmente para crianças. Afora a imprensa, até mesmo algumas produtoras, tais como a Sega e a Nintendo, passaram a se desentender por conta dos títulos violentos, sob o argumento de que tais gêneros eram um excesso que manchava a indústria, bem como que sua exploração se mostrava uma prática apelativa e anti-competitiva. Logo, frente a esse quadro de lançamentos violentos, de especulações quanto à influência dos jogos, de ausência de regulamentação dessa mídia e da difusão dos aparelhos de videogame domésticos, tiveram início, em 1993, diversas audiências no Congresso americano que tinham como intuito a regulação do conteúdo dos jogos eletrônicos. Em função disso, as produtoras de videogame decidiram se unir em um consórcio - a Interactive Digital Software Association, hoje conhecida como Entertainment Software Association (ESA) - para combater a tentativa de regulamentação estatal. Para tanto, criaram o Entertainment Software Rating Board (ESRB), um órgão de autoregulamentação do setor de videogames, que teria como função primordial

\footnotetext{
${ }^{9}$ GONZALES, Lauren. Op. cit., p.5.
} 
atribuir a classificação indicativa aos jogos eletrônicos, permitindo, assim, que os pais comprassem jogos com o conteúdo adequado para a faixa etária dos seus filhos, sem prejudicar, por outro lado, a venda de títulos adultos. Conforme destacado por Greeson, ainda que a ESRB tenha sido um sistema criado por força da necessidade,

Essa foi uma das medidas mais inteligentes tomadas pela indústria. Ela não apenas evitou a regulamentação estatal, mas finalmente introduziu o conceito de que os jogos não são apenas para crianças, e que nem todos os jogos são apropriados para todos os públicos. Ela também deu aos pais uma ferramenta valiosa para entender o conteúdo dos jogos e permitiu que eles tomassem a decisão se determinado material era, ou não, apropriado para os seus filhos. ${ }^{10}$

Independentemente das críticas ao sistema, a verdade é que a proposta da indústria dos jogos deu certo, o que permitiu que títulos como Mortal Kombat continuassem no mercado. No que se refere a esse último, cumpre salientar que ele não foi concebido para sobreviver da polêmica, como Custer's Revenge ou Death Race. Ao contrário, seu atrativo encontrava-se no seu caráter inovador e realista, o que surpreendeu o público daquela época. Assim sendo, mesmo sem os holofotes da imprensa, é provável que a série Mortal Kombat ainda fosse um sucesso, sendo inegável, contudo, o papel exercido pela publicidade no elevado número de vendas.

Depois do marco da criação da ESRB, as polêmicas envolvendo os jogos eletrônicos ganharam uma nova proporção com a ocorrência de grandes incidentes violentos, os quais foram rapidamente associados ao uso indiscriminado de videogames. De acordo com muitos especialistas, esses eventos sinalizavam que os jogos haviam cruzado a fronteira do simples mau gosto e se tornado catalisadores de tragédias reais. Em outras palavras, o que a indústria dos videogames estava vendendo não era mais um brinquedo, mas sim verdadeiros simuladores de crimes e atrocidades, os quais adentravam aos lares mascarados como simples forma de lazer. Entre

\footnotetext{
${ }^{10}$ Ibid. p.6.
} 
os fatídicos episódios, é possível destacar o tiroteio ocorrido na escola de Columbine, nos EUA, no qual Eric Harris e Dylan Klebold mataram doze colegas de sala e um professor antes de cometerem suicídio. De acordo com a jornalista Lauren Gonzales,

as pessoas queriam respostas, e como todo episódio violento antes ou depois de Columbine, videogames, televisão, música e filmes teriam que sofrer as conseqüências até que as pessoas entendessem (se é que um dia entenderam) o que realmente aconteceu de errado. Harris usava Ludox, um antidepressivo. Harris não foi aceito no exército - o que aparentemente importava muito para ele, segundo o Rocky Mountain News. Mas Doom deu a imprensa um alvo direto: Harris jogava Doom. Harris atirou e matou pessoas. Portanto... ${ }^{11}$

Dessa feita, Columbine foi responsável por macular o jogo Doom e reiniciar o choque entre defensores e críticos dos jogos. Nesse cenário, tamanha foi a responsabilidade atribuída aos jogos eletrônicos que, em 2001, diversos familiares das vítimas ajuizaram uma ação coletiva contra 25 empresas do setor de entretenimento, buscando indenização por danos punitivos no valor de cinco bilhões de dólares. A despeito da iniciativa, tal pleito acabou não logrando êxito, já que os juízes americanos não vislumbraram nexo de causalidade entre os eventos. ${ }^{12}$

Vale registrar, outrossim, que o Brasil não ficou imune à esse tipo de discussão, que teve seu início no país em 1999, logo após a tragédia ocorrida no Morumbi Shopping, em São Paulo. Em função do impacto que teve na jurisprudência brasileira, tal episódio merece um estudo mais detalhado, motivo pelo qual será abordado no capítulo seguinte.

De forma a sintetizar o exposto, cabe considerarmos a classificação proposta por Lauren Gonzales, a qual possui importante fim didático, mesmo tendo sido criada com base na realidade americana. Após abordar

\footnotetext{
${ }^{11}$ Ibid. p.7

${ }^{12}$ Em ação correlata, envolvendo outro tiroteio ocorrido em 1997, na Heath High School, o juiz federal Danny Boggs explicitou porque tais demandas não procedem: "Nós acreditamos que há um salto muito grande entre atirar em personagens numa tela (atividade realizada por milhões) $e$ atirar em pessoas numa sala de aula (atividade realizada por poucos)." James v. Meow Media, Inc. 300 F.3d 683, 6th Circuit Court of Appeals, 2002. Disponível em <http://caselaw.findlaw.com/us-6th-circuit/1400143.html> Acesso em 28 de outubro de 2010.
} 
todos os grandes jogos controversos, Gonzales reconheceu a existência de três grandes categorias de polêmica: a dos "Grandes Ofensores", a dos "Arriscados para o Varejo" e a dos "Protestos Pacíficos."

$\mathrm{Na}$ classe dos "Grandes Ofensores" encontram-se os jogos considerados tão violentos ou controversos que ensejam a intervenção estatal. São jogos que não só causam pandemônio no público, como também são retirados do mercado, enfrentam litígios, são banidos de países inteiros e chegam até mesmo a inspirar a criação de agências de classificação e novas leis. É nessa classe que se situam os jogos previamente mencionados.

Os “Arriscados para o Varejo”, a seu turno, são aqueles jogos que são controversos o suficiente para gerar insegurança entre os varejistas, que acabam retirando alguns exemplares das prateleiras, frente ao risco que representam. Dito de outra forma, são títulos que acabam sendo removidos do mercado, mas que não são polêmicos o suficiente para gerar a interferência do Estado. Na realidade, a resistência encontrada por essas obras é eminentemente privada, tal como ocorreu com o jogo $B M X X X X$, nos EUA. Quanto a esse, Gonzales traz uma consideração que merece destaque:

Steve Kent falou do BMX XXX usando GTA III como exemplo de um bom jogo com controvérsia: 'No mundo dos jogos, há uma clara regra de seleção natural. Quando GTA III foi lançado, era maravilhoso, era um jogo bem feito' ele disse. 'Ele, de fato, ultrapassou diversos limites. No entanto, a sociedade o viu como um jogo divertido, arrojado, e agora todos tentam criar cópias do gênero. Nesse contexto, surge a Acclaim com BMX XXX, no qual o jogador guarda pontos para ver vídeos de strippers. Advinha o quê? A sociedade achou que BMX XXX não prestava. Você vê mais alguém correndo para fazer jogos com vídeos de strippers? Não vê. ${ }^{13}$

Por fim, a categoria dos Protestos Pacíficos inclui os jogos que são alvos de discussão diminuta, em geral quando algum grupo se sente ofendido e quer chamar a atenção da sociedade. Na prática, tais jogos são vendidos normalmente, apenas com eventuais boicotes, mas nada que

\footnotetext{
${ }^{13}$ GONZALES, Lauren. Op. cit., p.14.
} 
interfira no seu sucesso. Entre esses, encontram-se jogos como Tomb Raider e Dead or Alive.

\subsection{Panorama atual}

Em conformidade com o seu passado, o cenário contemporâneo dos jogos eletrônicos ainda é marcado por muitas controvérsias. Todavia, existem algumas diferenças que merecem consideração. A primeira delas é que os jogos eletrônicos da $7^{\mathrm{a}}$ geração, como afirmado anteriormente, apresentam um grau de interatividade e realismo impressionantes, o que faz deles um instrumento mais audacioso e difundido entre as variadas faixas etárias. Quase como corolário da primeira, a segunda diferença reside no fato de que, com o avançar do processo de globalização e da popularização dos jogos, as medidas restritivas e discussões que antes se restringiam a algumas regiões se espalharam pelo globo. Dessa forma, entre os países que já tomaram algum tipo de medida quanto ao conteúdo dos jogos eletrônicos, ou nos quais pelo menos o assunto já esteve em pauta, encontram-se: Alemanha, Arábia Saudita, Austrália, Brasil, Canadá, China, Cingapura, Coréia do Sul, Emirados Árabes, Estados Unidos, França, Grécia, Inglaterra, Irlanda, Itália, Japão, Malásia, México, Nova Zelândia, Rússia, Tailândia e Venezuela ${ }^{14}$.

Insta-se salientar que nessa lista encontram-se países que proibiram determinados jogos por vontade política, tais como a Coréia do Sul e a China $^{15}$, o que reflete uma postura diferenciada em relação à liberdade de expressão como um todo, e não apenas quanto aos jogos eletrônicos. A respeito desses, o debate sobre a liberdade de expressão deve ser travado em uma esfera mais abrangente, e não apenas sob a ótica do videogame.

\footnotetext{
${ }^{14}$ WIKIPEDIA. List of banned videogames. Disponível em <http://en.wikipedia.org/wiki/List of banned video games $>$. Acesso em 28 de outubro de 2010. ${ }^{15}$ A título exemplificativo, a China proibiu a comercialização do jogo Football Manager 2005 por esse retratar o Tibete como um país independente. A Coréia do Sul, por sua vez, tinha como tradição banir jogos que mencionassem a guerra com a Coréia do Norte, de modo a evitar tensões entre os países vizinhos. Nada obstante, em dezembro de 2006, a Coréia do Sul anunciou que tais jogos não seriam mais banidos, de forma a assegurar o princípio da liberdade de expressão.
} 
Outros, por sua vez, possuem um repertório bastante pequeno de jogos proibidos, tais como a Inglaterra, Irlanda e a Nova Zelândia, enquanto que existem aqueles que sequer proibiram qualquer título, como Canadá e França. No entanto, apesar desse histórico positivo, a discussão sobre os limites dos jogos eletrônicos se faz presente em cada uma desses países, ensejando controvérsias até mesmo em países mais liberais, como os EUA.

Por essa breve exposição, percebe-se que o cenário atual dos jogos eletrônicos é, no mínimo, incerto, já que cada Estado possui uma postura e uma sensibilidade diferente para restringir a expressão nesse formato de mídia, o que impõe um sério desafio às produtoras de jogos, que precisam adaptar seus produtos para serem aceitos nos mais variados mercados. Tanto é verdade que, em episódio recente, a produtora Activision Blizzard teve que entrar em acordo com o governo russo para não ter o seu lançamento, Call of Duty: Modern Warfare 2, banido daquele mercado. O motivo se deu por conta da fase "No russian", que fora suprimida nas versões de alguns países da Comunidade dos Estados Independentes (CEI).

A polêmica gerada pela fase "No russian" é digna de menção porque traz consigo uma solução criada pela produtora para se antecipar às proibições estatais. Em linhas gerais, a fase retrata uma passagem em que um agente infiltrado em uma célula terrorista deve participar de uma chacina de civis russos em um aeroporto. Ainda que tal cena se justifique dentro da história, e o jogador possa acompanhar os terroristas sem disparar sequer um tiro, a produtora reconheceu que a cena se mostrou "muito forte" para alguns, razão pela qual desenvolveu um mecanismo que permite ao jogador "pular" essa cena, sem qualquer prejuízo para o desenvolvimento da trama. Com efeito, apesar de o jogo ser voltado para o público maior de 17 anos, é interessante notar como esses mecanismos de "autocensura" começam a se apresentar como uma saída das produtoras para não ofender os mais sensíveis, evitando, assim, prejuízos gigantescos com possíveis retiradas do mercado. 
Demonstrada a pertinência do estudo, daremos enfoque, em seguida, à realidade brasileira que, apesar de pouco preocupante se comparada à de alguns países, mostra-se excessivamente moralista em relação à de outros. 


\section{CAPÍTULO II: O CENÁRIO BRASILEIRO}

\subsection{Proibição dos jogos pelo Poder Executivo}

As primeiras proibições de jogos eletrônicos no Brasil ocorreram no ano de 1998, ainda pela atuação do Poder Executivo. Através de processos administrativos iniciados ex officio pelo Departamento de Proteção e Defesa do Consumidor, divisão da Secretária de Direito Econômico vinculada ao Ministério da Justiça, dois jogos tiveram sua comercialização vedada em território nacional, sob o argumento de que seriam lesivos à saúde dos consumidores. Foram eles Carmageddon, desenvolvido pela empresa Sci, e Grand Theft Auto - O Grande Ladrão de Carros, produzido pela empresa Rockstar North.

De forma sintética, Carmageddon tratava-se de um jogo de corrida tradicional, no qual o jogador deveria completar um percurso em um determinado espaço de tempo. Ocorre, todavia, que o jogador poderia aumentar seu tempo disponível se realizasse algumas "tarefas", tais como danificar os carros adversários ou atropelar pedestres. Adicionalmente, as corridas eram consideradas completas se o percurso fosse concluído na sua integralidade, se todos os carros adversários fossem destruídos ou se todos os pedestres fossem atropelados.

Grand Theft Auto - O Grande Ladrão de Carros, por sua vez, tratava-se de um jogo de ação que abordava temas adultos e polêmicos, tais como a exploração da prostituição, a venda de drogas, a prática de assassinatos ou o roubo de carros. O objetivo do protagonista era, nessa conjuntura, crescer no mundo da criminalidade, o que fazia do jogo um alvo fácil de repúdio social. Fora isso, esse jogo deu início a uma série que tem 
como marca registrada a sátira de episódios do cotidiano com bastante humor negro, o que por muitas vezes incomoda determinados segmentos. ${ }^{16}$

Em função da dificuldade de acesso a essas decisões, fruto da falta de catalogação das mesmas, pouco se sabe a respeito dessas duas proibições, exceto que elas já ocorreram em um dado momento. Nada obstante, apesar da decisão relativa ao jogo Carmageddon permanecer na obscuridade, ainda é possível localizar a decisão administrativa referente ao jogo Grand Theft Auto - O Grande Ladrão de Carros, a qual faz menção ao jogo anterior, também analisado pelo Departamento de Proteção e Defesa do Consumidor.

Nessa perspectiva, de acordo com o parecer exarado pelo Coordenador-Geral no processo administrativo de $\mathrm{n}^{\mathrm{o}}$ 08012.00039-4/98-74, a comercialização do jogo Grand Theft Auto - O Grande Ladrão de Carros deveria ser sustada porque daria margem à geração de anomalias de comportamentos nas relações sociais. Segundo seu entendimento:

O jogo, tanto o neste feito combatido, como o "Carmageddon" são instrumentos estimulantes de desvios de comportamentos, pois incitam os jogadores a atuarem contrários às regras de moral e bons costumes, principalmente ao confronto com autoridades públicas, com indagações como as: "QUEM DISSE QUE O CRIME NÃO COMPENSA?" (neste) e "OS POLITICAMENTE CORRETOS VÃO ODIAR" (no "Carmageddon"). ${ }^{17}$

Após essa exposição, o Coordenador-Geral opinou pela manutenção da proibição do jogo em referência, tendo como lastro a observância das disposições dos arts. 37, § $2^{\circ}$ e 68, do Código de Defesa do Consumidor (Lei 8.078/90). Em seguida, fez questão de frisar que aquela decisão não se tratava de "reinstalação da censura, como outrora, nem de classificação indicativa, mas de ato administrativo, no interesse público, em defesa da

\footnotetext{
${ }^{16}$ Para uma abordagem crítica desse aspecto do jogo, cf. PROTASIO, Arthur. Grand Theft Auto e a Contemporaneidade. Disponível em <http://vagrantbard.com/2010/08/16/grand-theft-auto-e-acontemporaneidade/>. Acesso em 28 de outubro de 2010.

${ }^{17}$ Secretaria de Direito Econômico (SDE), processo administrativo de no 08012.00039-4/98-74, diretor Nelson F. Lins D’Albuquerque Júnior. Brasília, 21 de maio de 1998. Disponível em $\langle$ http://www.mp.rs.gov.br/infancia/legislacaoc/legislacaoc/id2157.htm>. Acesso em 28 de outubro de 2010 .
} 
coletividade nos termos da citada lei" ${ }^{\text {18 }}$. Posteriormente, tal opinião foi acolhida pelo diretor do Departamento de Proteção e Defesa do Consumidor, tendo o seu despacho sido publicado no Diário Oficial da União de 21 de maio de 1998.

Irresignada com a proibição imposta, a empresa responsável pela importação do jogo impetrou um mandado de segurança, objetivando a nulidade desse despacho. Em sede de sentença, a segurança foi indeferida pelo magistrado, que entendeu que:

o despacho em questão que determinou a imediata retirada do produto do mercado, bem como a proibição de sua circulação, não constitui sanção. É a manifestação do próprio exercício do poder de polícia conferido à Administração Pública (...) Quanto ao produto em si, flagrante é sua nocividade. Depois de amplamente discutida a questão, conforme documentos acostados às fls. 43/106, não há como negar a potencialidade do referido CD-ROM como instrumento de incitação à violência no trânsito, o que faz dele nocivo à segurança da população no trânsito. ${ }^{19}$

Ainda inconformada com o desfecho proposto, a empresa apelou para o Tribunal Regional Federal da $1^{\mathrm{a}}$ Região, aduzindo, entre outros argumentos, que houve uma verdadeira e indisfarçável censura neste caso, restando a diferença entre censura e exercício do regular poder de polícia na fundamentação do ato: se eivada de subjetividade, seria censura; se fundamentada na comprovação do efeito negativo da arte, obra ou produto, seria o exercício do poder de polícia.

A despeito da argumentação da impetrante, a quinta turma do TRF da $1^{a}$ Região decidiu negar provimento ao apelo, por unanimidade, sob o argumento de que:

Tratando-se de medida cautelar, não há necessidade de apreciação aprofundada dos fatos e do direito, bastando a verossimilhança, que parece existir, no caso, uma vez que o jogo eletrônico em referência, no mínimo, está na contramão das campanhas de educação no trânsito, que têm como alvo, especialmente, os adolescentes. Por outro lado, não existia outra medida útil para a espécie, senão a

\footnotetext{
${ }^{18}$ Ibid.

${ }^{19} 22^{\mathrm{a}}$ Vara Federal da Seção Judiciária do Distrito Federal, sentença em mandado de segurança de no 1999.34.00.006327-6, Juiz Ênio Laercio Chappuis, publicado em 29 de março de 2000.
} 
retirada do produto de circulação, sob pena de se consumarem irreversivelmente as consequiências que se pretendem evitar. ${ }^{20}$

Dessa forma, o processo em referência teve seu trânsito em julgado em 19 de março de 2007, sendo finalmente consolidada a proibição do jogo, frente ao desinteresse da empresa em levar a questão para os tribunais superiores $^{21}$.

\subsection{Proibição dos jogos pelo Poder Judiciário}

Ultrapassada a primeira fase de intervenções pelo Poder Executivo, todas as outras proibições dos jogos eletrônicos foram provenientes de determinações do Poder Judiciário. Assim, dos 12 jogos sabidamente proibidos no Brasil, 2 tiveram seus destinos selados por processos administrativos, enquanto o restante foi censurado ${ }^{22}$ por decisões judiciais, proferidas em 4 processos distintos.

Inicialmente, cumpre destacar que os casos apresentados a seguir são meramente exemplificativos, tendo em vista que inexiste uma lista oficial de todos os jogos eletrônicos proibidos no Brasil. Desse modo, na falta de um catálogo específico, o processo de localização dos mesmos acaba dependendo da repercussão que eles geram na imprensa, a qual fornece as informações necessárias para a pesquisa jurisprudencial. Paralelamente, muitos dos jogos proibidos acabam circulando livremente pela internet, a

\footnotetext{
${ }^{20}$ Tribunal Regional Federal da $1^{a}$ Região, acórdão em mandado de segurança de $\mathrm{n}^{\mathrm{o}}$ 1999.34.00.006327-6/DF, Relator Des. João Batista Moreira, publicado em 01 de março de 2007.

${ }^{21}$ A falta de interesse da empresa em levar o caso adiante se justifica: passados nove anos desde a sua proibição, Grand Theft Auto já não tinha mais valor de mercado. Apenas para ilustrar a inconveniência do prosseguimento do feito, enquanto o TRF da $1^{\mathrm{a}}$ Região ainda discutia a viabilidade do primeiro jogo da série, sete sequências do mesmo já haviam sido lançadas, a saber: Grand Theft Auto 2 (1999); Grand Theft Auto III (2001); Grand Theft Auto: Vice City (2002); Grand Theft Auto: Advance (2004); Grand Theft Auto: San Andreas (2004); Grand Theft Auto: Liberty City Stories (2005); Grand Theft Auto: Vice City Stories (2006).

${ }^{22}$ É certo que existe grande debate doutrinário acerca da figura da "censura judicial", havendo quem sustente a impossibilidade de se falar em censura nos casos de intervenção do Poder Judiciário. Nada obstante, em que pese a discussão acadêmica, entende-se como censura judicial, para efeitos desse trabalho, a proibição de determinados jogos eletrônicos, pelo Poder Judiciário, em virtude dos seus conteúdos inadequados.
} 
despeito da proibição que lhes é imposta, o que dificulta ainda mais o processo de identificação dos mesmos.

Feitas essas considerações, quatro são os processos judiciais a serem analisados, na seguinte ordem cronológica: as ações civis públicas que resultaram na proibição dos jogos Blood, Doom, Duke Nuken, Mortal Kombat, Postal e Requiem (1999); Counterstrike e Everquest (2002); The Crims (2006); e a ação coletiva que resultou na proibição do jogo Bully (2008).

\subsubsection{Ação civil pública de no $1999.38 .00 .037967-8^{23}$}

O primeiro caso trata-se de uma ação civil pública proposta pelo Ministério Público Federal, na qual foi requerido que a União retirasse do mercado de consumo os jogos Blood, Doom, Duke Nuken, Mortal Kombat, Postal e Requiem, proibindo sua distribuição e comercialização. Adicionalmente, o parquet requereu que a União, enquanto Ministério da Justiça, fosse compelida a estabelecer critérios de classificação para todos os jogos eletrônicos, segundo a faixa etária a que se destinam e o conteúdo das mensagens que veiculam. Para tanto, sustentou, em síntese, que: (a) os jogos violentos e sádicos apresentados são atentatórios ao bem-estar físico, mental e social das crianças e dos adolescentes, bem como dos cidadãos em geral, do que se conclui que são nocivos à saúde destes consumidores, pois prejudicam o desenvolvimento da sua personalidade, podem gerar dependência e são anti-sociais; (b) é dever do Estado colocar crianças e adolescentes a salvo de toda forma de violência; e (c) deve constar nas embalagens de todos os jogos eletrônicos a síntese de seu conteúdo e a faixa etária a que se destinam, a fim de se atender à ordem de classificação das diversões infanto-juvenis. Frente aos argumentos apresentados, a magistrada julgou procedentes os pedidos postos na inicial, determinando

\footnotetext{
${ }^{23} 3^{\text {a }}$ Vara Federal da Seção Judiciária de Minas Gerais, sentença em ação civil pública de $n^{\circ}$ 1999.38.00.037967-8, Juíza Cláudia Maria Resende Neves Guimarães, Minas Gerais, publicado em 10 de outubro de 2000 .
} 
que os jogos em questão fossem proibidos, bem como fosse o Ministério da Justiça compelido a criar critérios para classificação indicativa. ${ }^{24}$ Nesse sentido, vale transcrever trechos da fundamentação da sentença, os quais expõem o convencimento da magistrada:

É fato notório que os jogos de computadores e videos games aludidos na inicial incitam a violência, disseminando o prazer pela dor, o ódio e a vontade de matar. O público alvo de tais jogos é composto de crianças e adolescentes, que se encontram, por sua vez, em fase de formação psicológica, quando, então, deve-se atentar para que lhes seja transmitido valores morais necessários à formação do caráter, conforme preceitua o art. 227 da Constituição Federal.

Se crianças e adolescentes passam horas do seu dia diante de jogos violentos, num mundo virtual, onde vence quem matar mais, é forçoso reconhecer, ou ao menos presumir, que tais vídeos assassinos afetam diretamente a estrutura psicológica dos mesmos, distorcendo valores socialmente exaltados, valorizando, ao contrário, aqueles que devem ser repugnados por toda a sociedade, tidos pelo ordenamento jurídico como ofensivos.

Esta magistrada analisou a prova de fls. 34, constante de uma fita de vídeo, com os jogos DOOM, POSTAL, MORTAL KOMBAT, REQUIEM, BLOOD e DUKE NUKEN e, de fato, é assombroso verificar o que se pode criar almejando lucro, não só deixando de lado todos os valores morais que devem permear a educação de nossas crianças e adolescentes, mas incitando o contrário: prazer de matar, de causar sofrimento, de aniquilar completamente o mais fraco. Não há qualquer sinal de piedade, misericórdia, solidariedade, etc., nada! Bom é aquele que mata mais.

(...)

Por fim, no jogo Duke Nuken: “... o assassino virtual entra em um shopping, mune-se de uma metralhadora, dirige-se ao cinema, adentra ao banheiro, atira no espelho, no reflexo de sua imagem. Após, dirige-se à platéia, à sala de exibição do filme, posta-se à frente dela e dispara rajadas contínuas de tiros para exterminar seus inimigos".

Com relação a este último DUKE NUKEN, este mundo virtual veio transmudar em realidade, quando o mesmo comportamento do vídeo foi repetido por Mateus Meira, em 03.11.99, no Shopping Morumbi em São Paulo, conforme relatou toda a imprensa falada e televisiva.

É necessário que toda a sociedade reflita sobre o que está ocorrendo com nossas crianças e adolescentes. O episódio ocorrido no Shopping Morumbi, bem como os documentos trazidos as fls. 36/122, em especial o parecer da Dra. Maria Alice Palhares, concluindo pela nocividade dos jogos referidos na inicial na formação psicológica das crianças e adolescentes são suficientes, ao meu sentir, para a procedência do pedido posto na inicial.

(...)

Pretender obstaculizar a diretriz trazida pelos arts. 226/227 da CF/88 invocando a livre manifestação do pensamento do art. 5o, IX e a liberdade do exercício das atividades (parágrafo único do art. 170 da $\mathrm{CF} / 88$ ), não é razoável. (...)

\footnotetext{
${ }^{24}$ À época do ajuizamento dessa ação, o Ministério da Justiça ainda não exercia a classificação indicativa dos jogos eletrônicos. Tal função apenas passou a ser exercida posteriormente, através do Departamento de Justiça, Classificação, Títulos e Qualificação (Dejus), órgão vinculado ao Ministério da Justiça.
} 
E mais. Sob a ótica das relações do consumo, os jogos virtuais aludidos na inicial são impróprios ao consumo, eis que na medida que são nocivos à saúde de seus consumidores, contrariam, além do Estatuto da Criança e do Adolescente, o Código de Proteção e Defesa do Consumidor, a teor do que dispõem os arts. $6^{\circ}$, inciso I, $8^{\circ}, 10^{\circ} \mathrm{e}$, em especial, o art. 39, inciso IV.

Posteriormente, já em sede de reexame necessário, o Tribunal Regional Federal da $1^{\text {a }}$ Região confirmou a sentença, ficando determinado, assim, que os jogos deveriam trazer afixados em suas embalagens o resumo do seu conteúdo e a faixa etária a que se destinam, bem como que os jogos apreendidos deveriam ser inutilizados. ${ }^{25}$

\subsubsection{Ação civil pública de no $2002.38 .00 .046529-6^{26}$}

No segundo caso, em ação correlata, o Ministério Público Federal requereu que a União Federal fosse compelida a proibir a distribuição e comercialização de quaisquer livros, encartes, revistas, CD Rom's, fitas de vídeo-game ou computador dos jogos Counterstrike e Everquest, bem como fossem retirados do mercado de consumo os exemplares já existentes do primeiro jogo (já que o segundo não havia sido lançado oficialmente no Brasil). De forma a embasar seu pedido, o parquet alegou que os jogos virtuais de videogame e computadores atentam contra os princípios diretivos da educação de crianças e adolescentes, vindo mesmo a causarlhes danos à saúde física e mental, sendo fatores de propulsão à violência e deturpadores da formação psicológica e da personalidade de crianças e adolescentes. O magistrado, a seu turno, deu razão ao pleito ministerial, julgando procedente a demanda e determinando a proibição dos jogos supra mencionados. Vale ressaltar que, em sua sentença, o magistrado reproduziu por completo a fundamentação apresentada no caso anterior, acrescentando que:

\footnotetext{
${ }^{25}$ Tribunal Regional Federal da $1^{a}$ Região, acórdão de no 1999.38.00.037967-8/MG, Relator Des. João Batista Moreira, publicado em 29 de outubro de 2009.

${ }^{26} 17^{\mathrm{a}}$ Vara Federal da Seção Judiciária de Minas Gerais, sentença em ação civil pública de ${ }^{\circ}$ 2002.38.00.046529-6, Juiz Carlos Alberto Simões de Tomaz, Minas Gerais, publicado em 08 de agosto de 2007.
} 
É contra a comercialização desses jogos que o Ministério Público Federal se insurge, com escopo de tornar eficazes as normas de proteção à criança e ao adolescente insertas na Constituição Federal e na legislação infraconstitucional. E nesse mister razão assiste ao autor, porque, embora o Ministério da Justiça tenha tomado medidas restritivas quanto à venda desses jogos, estas não se mostraram eficazes, à medida que esses jogos continuam atingir as crianças e adolescentes.

Ora, a violência gera violência. É verdade. Contudo, o fundamento deste julgado, não se baseia apenas nessa premissa. Tem por esteio as normas constituições e infraconstitucionais de proteção à família, à criança e ao adolescente (destacados na sentença acima transcrita), bem como em parecer técnico elaborado por profissional competente, no qual são evidenciados os malefícios causados por esses jogos, não apenas às crianças e adolescentes, como também a pessoas de faixas etárias outras, conforme ficou bem assentado na sentença transcrita acima e documentos que instruíram a inicial.

(...)

De fato, a questão se agrava ainda mais, conforme relatado pelo Ministério Público Federal às fls. 06/08, à medida que o jogo COUNTER-STRIKE, fabricado nos Estados Unidos e adaptado no Brasil, 'virtualiza' uma cena de embate entre a Polícia do Estado de Rio de Janeiro e traficantes entrincheirados nas favelas, tendo por fundo musical um funk proibido. Na visão de especialistas, esse jogo ensina técnica de guerra, uma vez que o jogador deve ter conhecimento sobre táticas de esconderijo, como se estivesse numa guerrilha, com alternativas de terrorista e contra-terrorista, táticas de ataque e defesa. Com efeito, essas cenas, bem descritas naquelas páginas, trazem imanentes estímulos à subversão da ordem social, atentando contra o estado democrático e de direito e contra a segurança pública, impondo sua proibição e retirada do mercado.

\section{Tal processo encontra-se atualmente no Tribunal Regional Federal}

da $1^{\text {a }}$ Região, aguardando apreciação em sede de reexame necessário. Enquanto isso não ocorre, os efeitos da sentença em referência estão suspensos, devido ao acórdão proferido em medida cautelar, assim ementado:

PROCESSUAL CIVIL. JOGOS ELETRÔNICOS. PROIBIÇÃO DE COMERCIALIZAÇÃO. INTERESSE DE AGIR. PRINCÍPIO DO PROMOTOR NATURAL. VIOLAÇÃO NÃO CONFIGURADA. REQUISITOS LEGAIS PREENCHIDOS. MEDIDA CAUTELAR DEFERIDA.

1. O interesse de agir da Autora encontra-se configurado em razão de as apreensões do jogo eletrônico por ela distribuído estarem sendo efetivadas em cumprimento à tutela específica concedida na sentença proferida na Ação Civil Pública 2002.38.00.046529-6. Inexistência de carência do direito de ação.

2. Não há violação ao princípio do promotor natural se foi renovada a citação do MPF na Procuradoria Regional da República em ação cautelar de competência originária do Tribunal Regional Federal e se não houve alegação ou demonstração de prejuízo à defesa.

3. Há plausibilidade do direito quanto a pretensão de manutenção da comercialização de jogo distribuído no país há mais de 10 anos e classificado pelo Ministério da Justiça como recomendado para maiores de 18 anos, uma vez que a tutela judicial não se destina a proteger exclusivamente direitos de crianças 
e adolescentes; que não há demonstração de prejuízo à saúde física ou psíquica de pessoas usuárias de qualquer faixa etária.

4. O periculum in mora decorre de situação de dano ou prejuízo que pode ser ocasionado à empresa em razão da suspensão da comercialização do jogo. Inexistência de periculum in mora inverso em razão da ausência de caso específico capaz de revelar ocorrência de alucinações, de surtos epiléticos ou prática de atos de violência pelos usuários do jogo em razão de sua utilização.

5. Medida cautelar concedida para suspender os efeitos da sentença. ${ }^{27}$

\subsubsection{Ação civil pública de $n^{\circ} \mathbf{2 0 0 6 . 3 8} .00 .014197-6^{28}$}

No terceiro caso de censura judicial aos jogos eletrônicos, o Ministério Público Federal propôs uma ação civil pública objetivando a proibição do jogo The Crims, sob a alegação de que o mesmo configuraria prática de apologia ao crime. Ao decidir sobre o pedido de antecipação de tutela, o magistrado explicitou que "não são poucas as situações concretas em que é evidenciada a estreita correlação entre a violência experimentada por meios eletrônicos e tragédias da vida cotidiana”, sendo mais uma vez utilizado como referência a tragédia ocorrida no Shopping Morumbi, em 1999. Em seguida, o magistrado realizou a seguinte construção:

Com efeito, os direitos, mesmo os constitucionalmente garantidos, não são, em geral, absolutos, e merecem interpretação sistemática de modo a sopesá-los e harmonizá-los com outros de igual ou até maio estatura. Nesse contexto, note-se que, entre nós, embora sejam livres a manifestação do pensamento e da atividade intelectual e artística, vedada a censura, art. $5^{\circ}$, IV e IX, da CF/88, também goza de especial relevo a proteção da criança e do adolescente, a quem é assegurado, com absoluta prioridade, o direito à vida, à dignidade, ao respeito, à convivência familiar e comunitária, sendo ainda dever da sociedade, família e Estado mantêlos a salvo de toda forma de negligência, discriminação, exploração, violência, crueldade e opressão, caput do art. 227 da Carta Magna.

Donde se conclui que é livre toda forma de expressão e manifestação do pensamento desde que daí não resulte a prática de conduta vedada pelo ordenamento jurídico-constitucional pátrio, como, in casu, a exposição de crianças e adolescentes a mensagens de violência gratuita, exortação à criminalidade e completa inversão dos valores inerentes a uma sociedade justa e solidária. Induvidoso, nessa toada, que o princípio constitucional do amparo à criança e ao adolescente é de maior relevância que o da garantia à liberdade de manifestação do pensamento.

\footnotetext{
${ }^{27}$ Tribunal Regional Federal da $1^{\text {a }}$ Região, acórdão em medida cautelar inominada de $\mathbf{n}^{\mathbf{o}}$ 2008.01.00.010959-9, Relator convocado Juiz Rodrigo Navarro de Oliveira, publicado em 29 de junho de 2009.

${ }^{28} 19^{\text {a }}$ Vara Federal da Seção Judiciária de Minas Gerais, sentença em ação civil pública de $n^{\circ}$ 2006.38.00.014197-6, Juiz João César Otoni de Matos, Minas Gerais, publicado em 27 de maio de 2010 .
} 
Com base nesse entendimento, o magistrado posteriormente ratificou sua decisão liminar, determinando o bloqueio de páginas e suportes relacionados ao acesso do jogo no Brasil. Ainda aguarda desfecho em $2^{\mathrm{a}}$ instância.

\subsubsection{Ação coletiva de no $10800832357^{29}$}

Por fim, a questão da proibição dos jogos eletrônicos se reacendeu, em 2008, após a ação coletiva ajuizada pelo Ministério Público do Rio Grande do Sul, a qual culminou com a proibição do jogo Bully. Segundo o Ministério Público, tal jogo deveria ser proibido por "retratar situações ditadas pela violência, provocação, corrupção, humilhação e professores inescrupulosos, nocivo à formação de crianças e adolescentes e ao público

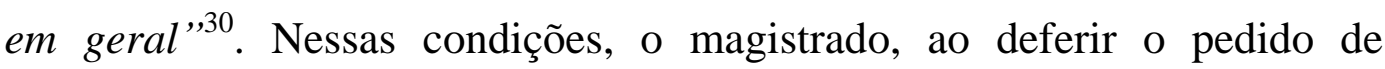
antecipação de tutela, entendeu que "o jogo se mostra efetivamente impróprio aos educandos e que a sociedade perde a capacidade de bem educar seus filhos à medida que jogos com enfoque idêntico a 'Bully' fazem trabalho em sentido contrário. "31 Nada obstante, ao contrário dos demais, nesse caso houve acordo entre as partes, razão pela qual foi proferida sentença homologatória que pôs fim ao litígio.

\subsection{Proibição dos jogos pelo Poder Legislativo}

Em paralelo à atuação do Poder Judiciário, existem também investidas do Poder Legislativo que visam proibir - ou ao menos regular determinados conteúdos dos jogos eletrônicos. É certo que, até a presente data, nenhum projeto de lei sobre o assunto foi aprovado. Ainda assim, as

\footnotetext{
${ }^{29} 16^{\text {a }}$ Vara Cível do Foro Central de Porto Alegre, ação coletiva de $n^{\circ} 10800832357$, Juiz Flávio Mendes Rabello, Porto Alegre, publicado em 04 de abril de 2008.

${ }^{30} \mathrm{G} 1$ - TECNOLOGIA. Justiça proíbe jogo 'Bully' no Rio Grande do Sul. Disponível em <http://g1.globo.com/Noticias/Tecnologia/0,,MUL393950-6174,00.html >. Acesso em 28 de outubro de 2010.

${ }^{31} 16^{\mathrm{a}}$ Vara Cível do Foro Central de Porto Alegre, decisão liminar em ação coletiva de ${ }^{\circ}$ 10800832357, Juiz Flávio Mendes Rabello, Porto Alegre, publicado em 04 de abril de 2008.
} 
medidas do Poder Legislativo se mostram como a maior ameaça à liberdade de expressão nos jogos eletrônicos, uma vez que as normas propostas, pela sua própria essência, são dotadas de abstração e generalidade. Por conseguinte, enquanto as decisões judiciais são pautadas pelo devido processo legal e pela análise minuciosa das obras questionadas, as leis pretendidas atacam todos os jogos considerados violentos ${ }^{32}$, sem atentar para as particularidades de cada espécie. Por essa mecânica, jogos como Manhunt e SWAT 4 seriam proibidos pelo mesmo fundamento - por serem violentos - apesar do primeiro ter como objetivo a prática de assassinatos, enquanto o segundo incentiva o uso de soluções pacíficas, sendo a violência o último recurso a ser empregado.

Dito isso, o cenário legislativo concernente aos jogos eletrônicos é composto de 12 projetos de leis oriundos da Câmara dos Deputados ${ }^{33}$, dentre os quais 7 ainda se encontram em tramitação, e 1 projeto de lei de iniciativa do Senado Federal.

Pela leitura das justificativas dos deputados federais, é possível perceber como todos os projetos de lei baseiam-se em generalizações e estereótipos criados em torno da figura do videogame, bem como se amparam na recorrente tese de que os jogos violentos são impróprios para o consumo e estimulam a prática de crimes. Contudo, apesar dessa uniformidade de justificativas, as soluções apresentadas para o problema não são as mesmas, havendo quem entenda que os jogos violentos devem ser sumariamente proibidos (corrente pró-proibição), enquanto outros

\footnotetext{
${ }^{32}$ Afinal, o que é violência? Segundo o dicionário Aurélio, entende-se por violento o ato "que se exerce com força, em que se faz uso de força bruta". Já o dicionário Houaiss define violência como "ação ou efeito de violentar, de empregar força fisica (contra alguém ou algo) ou intimidação moral contra (alguém); ato violento, crueldade, força". A OMS, por sua vez, diz ser "a imposição de um grau significativo de dor e sofrimento evitáveis". Observa-se, portanto, o desafio a ser enfrentado pelo bom legislador, já que definir o que se entende por "jogos violentos" é fundamental para garantir a segurança jurídica de todos os envolvidos com essa mídia. É devido a essa dificuldade conceitual que Anthony Asblaster afirma, no dicionário do pensamento social do século XX, que "não existe uma definição consensual ou incontroversa de violência. O termo é potente demais para que isso seja possivel."

33 São eles: PL 1654/96; PL 3611/00; PL 2566/00; PL 5172/05; PL 4932/05; PL 6868/06; PL 7319/10; PL 4052/1998; PL 3289/2000; PL 2870/2000; PL 45/2002; PL 6268/2005.
} 
defendem apenas a restrição de acesso para menores de idade (corrente prórestrição). De forma resumida, os objetivos desses projetos são:

PL 1654/1996 - Proíbe a fabricação, importação e comercialização de jogos eletrônicos e programas de computador de conteúdo obsceno ou violento.

PL 3611/2000 - Proíbe a venda e o aluguel de fitas de vídeo-game de conteúdo violento a menores de 21 anos.

PL 2566/2000 - Estabelece penalidade a quem permitir o acesso de adolescente menor de 16 anos a jogos eletrônicos que incentivem a violência.

PL 4932/2005 - Pró́be a freqüência e o manuseio nos estabelecimentos comerciais e clubes de lazer, por crianças e adolescentes, de programas informatizados de jogos de quaisquer espécies que induzam ou estimulem a violência.

PL 5712/2005 - Dispõe sobre a proibição da comercialização e locação de jogos eletrônicos que contenham cenas de violência contra policiais e dá outras providências.

PL 6868/2006 - Obriga os estabelecimentos que exploram jogos eletrônicos com temas de violência ou atentatórios à moral a destinarem área restrita para esse fim. Adicionalmente, proíbe a venda desses jogos às crianças e adolescentes.

PL 7319/2010 - Disciplina a organização e funcionamento de estabelecimento comercial, quanto à proibição de locação e venda de videogames que contenham cenas de violência.

Apesar do expressivo número de projetos em tramitação na Câmara dos Deputados, tem sido o projeto de lei 170/06, de autoria do Senador Valdir Raupp, que tem mais chamado a atenção da imprensa e dos críticos. Em que pese a sua popularidade, o projeto do senador não se distancia muito dos motivos e propostas já apresentados pelos deputados federais. Seu intuito é alterar o art. 20 da Lei $n^{\circ} 7.716 / 89$ (popularmente conhecida como lei do racismo) para incluir, entre os crimes nela previstos, o ato de fabricar, importar, distribuir, manter em depósito ou comercializar jogos de videogames ofensivos aos costumes, às tradições dos povos, aos seus cultos, credos, religiões e símbolos. Após receber um parecer favorável da Comissão de Educação, Cultura e Esporte, o projeto de lei em atento encontra-se, desde 25 de fevereiro de 2010, distribuído à Comissão de Constituição, Justiça e Cidadania, aguardando elaboração de relatório. De todo modo, é válido registrar que, apesar de levantar a bandeira da proibição dos jogos eletrônicos, nem mesmo o próprio senador acredita na eficácia da sua proposta, como se infere da seguinte justificativa dada à 
imprensa: "O problema é que o videogame descambou para uma liberalização geral (...) A gente sabe que é difícil essa lei ser aplicada, mas é uma forma de inibir um pouco a clandestinidade e os jogos que atentam contra a conduta." 34

Por fim, cumpre mencionar que as tentativas de regulação não se restringem à União, já que há precedentes de Estados membros legislando sobre a matéria. Apenas a título exemplificativo, é possível citar a Lei ${ }^{\circ}$ 3.634/2003, oriunda do município do Rio de Janeiro, que proíbe a freqüência, em qualquer horário ou dia, e o manuseio nas lojas comerciais e shopping centers por crianças e adolescentes, de programas informatizados, de quaisquer espécies de jogos, que induzam e estimulem a violência, ficando estabelecidas como penalidades a advertência administrativa, a suspensão do alvará de funcionamento e a cassação do alvará de funcionamento com multa. A realidade carioca, todavia, se distancia dessa previsão normativa, sendo raros os estabelecimentos que possuem uma área separada e vigiada para jogos com conteúdos violentos.

\footnotetext{
${ }^{34}$ ALMEIDA, Eduardo. Projeto de lei pretende proibir videogames ofensivos no país. Disponível em <http://oglobo.globo.com/tecnologia/mat/2009/12/14/projeto-de-lei-pretende-proibirvideogames-ofensivos-no-pais-915188685.asp>. Acesso em 28 de outubro de 2010.
} 


\section{CAPÍTULO III: REFLEXÕES SOBRE A PROIBIÇÃO DOS JOGOS ELETRÔNICOS}

\subsection{Desconstruindo premissas equivocadas}

Após o estudo das decisões brasileiras - tanto as judiciais, como as administrativas -, percebemos que, ainda que pouco numerosas, todas se pautaram em duas premissas: (i) que o público alvo dos jogos eletrônicos é composto predominantemente (ou até mesmo exclusivamente) de crianças e adolescentes, os quais se encontram em fase de formação psicológica e merecem ser resguardados de conteúdos inadequados; e (ii) que é notório que os jogos considerados "controversos", esses entendidos como os que tratam de violência, sexo ou drogas, disseminam valores inapropriados, causam malefícios ao jogador e podem, por fim, incitar a prática de crimes. De fato, é preciso que a sociedade analise essa questão, como fora mencionado por um dos magistrados, mas tal tarefa deve ser realizada cautelosamente, de modo a evitar idiossincrasias.

Ao analisarmos os pressupostos mencionados, constatamos que os mesmos não se sustentam. No que se refere ao primeiro, qual seja de que os jogos eletrônicos são brinquedos de criança, o que se verifica é uma visão antiquada que não corresponde mais à realidade. Embora no passado os jogos tenham sido predominantemente objeto de entretenimento infantojuvenil, pesquisas recentes revelam que a idade média do jogador de videogame passou a ser de 35 anos $^{35}$, fato esse que já chamou a atenção de diversas produtoras, que preparam lançamentos exclusivos para essa faixa etária. Assim, não podemos ignorar o fato de que houve uma sensível mudança no público alvo dos jogos desde a sua idealização, no final da década de 40, até os dias de hoje. Por tal razão, esse é um preconceito que deve ser superado não só pelos julgadores, mas pela sociedade, como um

\footnotetext{
${ }^{35}$ O GLOBO - TECNOLOGIA. Nova leva de games de combate mira no público acima dos 30. Disponível em <http://oglobo.globo.com/tecnologia/mat/2010/01/21/nova-leva-de-games-decombate-mira-no-publico-acima-dos-30-915664756.asp>. Acesso em 28 de outubro de 2010.
} 
todo. Já o segundo pressuposto, referente aos malefícios que os jogos podem causar ao jogador, é fruto de uma relação de causa e efeito artificial, a qual é geralmente reforçada em virtude de incidentes trágicos, tal como o tiroteio reiteradamente mencionado nas decisões judiciais, ocorrido no Morumbi Shopping, em São Paulo. Nesse episódio, inédito no país até então, o estudante de medicina Mateus da Costa Meira entrou em uma sala de cinema do Morumbi Shopping e, disparando uma submetralhadora, matou três pessoas e feriu outras cinco. Ainda espantados com a atrocidade ocorrida, a sociedade e a imprensa logo começaram a procurar um motivo, alguma explicação que justificasse esse incidente. Não demorou muito, como nas tragédias das escolas americanas, para que os jogos eletrônicos fossem considerados catalisadores dessa tragédia, sendo que, nessa oportunidade, o responsável foi o jogo Duke Nuken 3D, da empresa americana $3 D$ Realms. Isso porque, para muitos, as semelhanças entre o jogo e a realidade eram impressionantes. Como transcrito por um dos magistrados, no jogo Duke Nuken 3D:

o assassino virtual entra em um shopping, mune-se de uma metralhadora, dirigese ao cinema, adentra ao banheiro, atira no espelho, no reflexo de sua imagem. Após, dirige-se à platéia, à sala de exibição do filme, posta-se à frente dela e dispara rajadas contínuas de tiros para exterminar seus inimigos. ${ }^{36}$

Apesar dessa descrição não ser fiel ao título ${ }^{37}$, é inevitável perceber que a primeira geração de jogos proibidos no Brasil está intrinsecamente ligada a esse evento, que conseguiu influenciar, ainda, algumas das proibições ulteriores. Nesse particular, é curioso notar o grau de responsabilidade atribuído ao jogo, se comparado a outros fatores mais

\footnotetext{
${ }^{36} 3^{\text {a }}$ Vara Federal da Seção Judiciária de Minas Gerais, sentença em ação civil pública de $n^{\circ}$ 1999.38.00.037967-8, Juíza Cláudia Maria Resende Neves Guimarães, Minas Gerais, publicado em 10 de outubro de 2000.

${ }^{37}$ Ao afirmar que o jogo Duke Nuken 3D se desenvolve dessa forma, ignora-se a interatividade inerente aos jogos eletrônicos, nos quais a narrativa vai sendo moldada conforme as escolhas do jogador, em maior ou menor grau. Dessa forma, ao contrário da mídia do cinema, que possui uma narrativa pré-definida pelo diretor, os jogos eletrônicos permitem que o jogador faça escolhas, sejam elas relevantes, ou não, as quais interferem no desenvolvimento da trama principal. Nesse sentido, vale conferir a aludida cena do jogo e comparar com os fatos narrados. Disponível em <http://www.youtube.com/watch?v=H6JcZv3wPuU > Acesso em 28 de outubro de 2010.
} 
relevantes $^{38}$, como o uso de drogas, a personalidade introvertida e esquizóide do atirador, a abstenção do uso dos medicamentos antipsicóticos que controlavam seus sintomas de delírios, alucinações, irritabilidade e agressividade, meses antes da ocorrência da tragédia, e talvez o dado mais chamativo de todos - o atirador confessou que pensava em cometer o crime em um lugar conveniente (leia-se: sem detector de metais) desde $1992^{39}$, sendo que o jogo Duke Nuken 3D só foi lançado em 1996.

A verdade é que, por trás de toda proibição ou tentativa de regulação, existe um suposto estudo científico que comprova a relação de causa e efeito entre o uso de jogos violentos e a prática de atos violentos. De fato, não há como negar a existência de tais estudos, alguns, inclusive, de instituiçõos prestigiadas. Com efeito, um dos maiores defensores da periculosidade dos jogos violentos é Craig A. Anderson, professor e diretor do centro de estudos sobre violência da Iowa State University. Em estudo recente, publicado pela American Psychological Association, Anderson e mais sete professores de universidades americanas concluíram que

as evidências sugerem fortemente que a exposição à videogames violentos é um fator de risco para o aumento do comportamento agressivo, da percepção agressiva, e de efeitos agressivos, bem como pelo decréscimo da empatia e do comportamento social. ${ }^{40}$

Ao tratar desse trabalho, o professor L. Rowell Huesmann, da University of Michigan, corroborou os estudos realizados por Anderson e os demais, fazendo, contudo, uma ressalva importante:

A meta-análise realizada por Anderson et al. (2010) é a melhor até agora no sentido de comprovar, além de uma dúvida razoável, que a exposição à violência nos jogos eletrônicos aumenta o risco do observador se comportar de maneira

\footnotetext{
${ }^{38}$ LIMA, Maurício; ZAKABI, Rosana. O horror fora da tela. Disponível em $<$ http://veja.abril.com.br/101199/p_038.html> Acesso em 28 de outubro de 2010.

${ }^{39}$ Id., Penso nisso há sete anos. Disponível em <http://veja.abril.com.br/101199/p_038a.html > Acesso em 28 de outubro de 2010.

${ }^{40}$ ANDERSON, Craig et al. Violent Video Game Effects on Aggression, Empathy, and Prosocial Behavior in Eastern and Western Countries: A Meta-Analytic Review. Disponível em <http://www.psychology.iastate.edu/faculty/caa/abstracts/2010-2014/10ASISBSRS.pdf > Acesso em 28 de outubro de 2010. p.1.
} 
mais agressiva e violenta no futuro. "Aumenta o risco", evidentemente, não significa "determina". Há um aumento da probabilidade de comportamentos agressivos entre alguns indivíduos de uma população exposta, mas nenhuma alteração comportamental significativa ocorrerá para muitos dos outros expostos. $^{41}$

Por fim, em outro trabalho, Anderson tenta derrubar o argumento mais utilizado pelos defensores dos jogos violentos, ao dizer que:

O garoto de 14 anos, que diz jogar jogos violentos há anos e até hoje não matou ninguém, está absolutamente correto no que concerne à rejeição da tese extrema da causalidade "necessária e suficiente", assim como está certo o adulto de 45 anos que fuma 2 pacotes de cigarros por dia e constata não ter desenvolvido câncer de pulmão. Nada obstante, ambos estão errados ao inferir que a exposição aos respectivos fatores de risco (mídia violenta e cigarros) não aumentou a probabilidade de que eles, ou as pessoas ao seu redor, sofram as conseqüências desses comportamentos arriscados. ${ }^{42}$

Ainda que possa parecer conclusiva, essa linha de estudos não é a única existente sobre a matéria. Ocorre que os psicólogos ainda não entraram em consenso sobre a metodologia a ser utilizada nesse tipo de pesquisa, o que enseja questionamentos quanto aos resultados positivos já encontrados. É o que explica o professor Jeffrey Goldstein, da Utrecht University, na Holanda:

Eu já li quase todas as pesquisas publicadas em língua inglesa sobre jogos eletrônicos, entre os quais estão incluídos videogames e jogos de computador, CD-ROM e jogos online. Nem a quantidade, nem a qualidade das pesquisas sobre os jogos de videogame fazem muito para inspirar confiança nas conclusões sobre seus efeitos. Quase todos os estudos sofrem de definições pouco claras (de violência ou agressividade), medidas ambíguas (confundindo o jogar agressivo com comportamento agressivo; ou se utilizando de medidas questionáveis de agressão, como explosões de ruído ou de auto-relatos de agressões anteriores), e generalizações dos dados. Estudos que afirmam analisar os efeitos dos jogos eletrônicos raramente estudam a ação de jogar, na realidade. ${ }^{43}$

\footnotetext{
${ }^{41}$ HUESMANN, L. Rowell. Nailing the Coffin Shut on Doubts That Violent Video Games Stimulate Aggression: Comment on Anderson et al. (2010). Washington D.C.: Psychological Bulletin, vol. 136 (2), março de 2010. p.179-181.

${ }^{42}$ ANDERSON, Craig et al. The Influence of Media Violence on Youth. Disponível em <http://www.psychologicalscience.org/pdf/pspi/pspi43.pdf $>$ Acesso em 28 de outubro de 2010. p.83.

${ }^{43}$ KUTNER, L.; OLSON, C. K. Grand theft childhood: the surprising truth about violent video games and what parents can do. Nova Iorque: Simon \& Schuster, 2008. p.59.
} 
Dessa feita, na frente de uma segunda linha de pesquisa encontramse nomes como Christopher J. Ferguson e John Kilburn, da Texas A\&M International University, Jonathan Freedman, da Toronto University, e Lawrence Kutner e Cheryl K. Olson, co-fundadores e diretores da Harvard Medical School Center for Mental Health and Media.

De acordo com Ferguson, "videogames violentos são como manteiga de amendoim - inofensivos para a vasta maioria das crianças, mas prejudiciais para uma pequena minoria com problemas de personalidade ou saúde mental pré-existentes" ${ }^{\prime 4}$. Ainda segundo ele, pesquisas recentes demonstraram que, com o avanço na popularidade dos videogames, as crianças dos Estados Unidos e Europa têm mostrado menos problemas de comportamento, são menos violentas e se saem melhor nos testes escolares padronizados, o que significa que os jogos violentos não criaram uma geração de jovens violentos. Em crítica similar, a socióloga Karen Sternheimer afirma que os estudos sobre os efeitos dos jogos não demonstram que a violência na mídia gera comportamentos agressivos, mas sim que os dois fenômenos coexistem. ${ }^{45}$

$\mathrm{Na}$ mesma linha de raciocínio, Freedman ataca as falhas metodológicas das pesquisas que sustentam a relação entre a violência virtual e a real. Em um dos seus trabalhos, o autor conclui dizendo que os estudos existentes são muito pouco significativos ou sofrem de sérios problemas de metodologia; que pouca atenção foi dada para os jogos similares aos violentos, de modo a verificar se é o elemento "violência" que induz a agitação no jogador; que não se tentou eliminar, ou ao menos diminuir, a sensação de "experiência" no público estudado, o que

\footnotetext{
${ }^{44}$ REANEY, Patrícia. Videogames violentos são inofensivos para maioria das crianças. Disponível em <http://portalexame.abril.com.br/tecnologia/noticias/videogames-violentos-saoinofensivos-maioria-criancas-568045.html> Acesso em 28 de outubro de 2010.

${ }^{45}$ STERNHEIMER, Karen. Do videogames kill? Disponível em <http://www.theesa.com/facts/STERNHEIMERCONTEXTSARTICLE.pdf> Acesso em 28 de outubro de 2010.
} 
invariavelmente afeta a imparcialidade da pesquisa; e, finalmente, que as medidas de agressão utilizadas são absolutamente questionáveis. ${ }^{46}$

Já Lawrence Kutner e Cheryl K. Olson foram os responsáveis por uma pesquisa iniciada em 2004, com o patrocínio do governo americano, que buscou entender melhor os efeitos dos jogos de videogame. Após 4 anos de estudo, os resultados transformaram-se em um livro, denominado Grand Theft Childhood: the surprising truth about violent video games and what parents can do, obra na qual a mídia do videogame foi desmistificada para o público em geral.

Como os autores deixam claro, é possível falar em uma relação entre violência e jogos eletrônicos, mas não em causalidade. Inclusive, ao tratar do tema violência, os autores demonstraram como a própria sensibilidade da sociedade varia com o passar do tempo, razão pela qual o jogo considerando inadequado hoje pode ser visto como inofensivo no futuro. É o que se verifica na seguinte passagem:

Hoje vemos romances baratos, os filmes de gangsters e as histórias em quadrinhos como peças de época fantásticas e inofensivas. No entanto, nos anos que seguiram a sua introdução, todos foram rotulados por políticos, líderes religiosos, ativistas sociais e até mesmo alguns profissionais de saúde como disseminadores da destruição de valores morais, da cultura, do Estado de direito até mesmo da própria civilização. Entre as alegações: a leitura de contos de aventura levaria as crianças para a vida de corrupção e degradação. Assistir a filmes levaria as crianças a abandonarem os seus valores morais e a roubarem lojas e dinamitarem trens. Quadrinhos ensinariam e inspirariam seus leitores a cometerem estupros e roubos. Em retrospectiva, essas acusações parecem absurdas e até risíveis. A História mostrou que esses medos terríveis eram completamente injustificados. No entanto, por mais escandalosos que tenham sido, eles carregam uma semelhança impressionante, tanto no tom, quanto no conteúdo, com as preocupações atuais sobre os efeitos das mídias violentas especialmente os jogos de videogame - na juventude. ${ }^{47}$

Nessas condições, os atuais críticos dos jogos eletrônicos estão vociferando as mesmas preocupações já levantadas há três gerações atrás,

\footnotetext{
${ }^{46}$ FREEDMAN, Jonathan. Evaluating the Research on Violent Video Games. Disponível em $<$ http://culturalpolicy.uchicago.edu/papers/2001-video-games/freedman.html > Acesso em $28 \mathrm{de}$ outubro de 2010.

${ }^{47}$ KUTNER, L.; OLSON, C. K. Grand theft childhood: the surprising truth about violent video games and what parents can do. p. 30 .
} 
no período de introdução dos novos tipos de mídia. Grande parte deles tem boas intenções, buscando proteger as crianças de influências negativas. Contudo, há também aqueles que usam do tema para promoção pessoal, apelando para o desconhecimento e o receio dos pais. Independentemente dos intuitos positivos ou interesses escusos, o grande problema, na realidade, é que muitas das críticas são baseadas em evidências escassas, presunções imprecisas ou pseudociências. ${ }^{48}$

No que tange à questão metodológica, Kutner e Olson são tão incisivos quanto Freedman, já que, para eles, as pesquisas falham em não diferenciar "agressão" de "violência". Ao não fazê-lo, chega-se a conclusão de que os sujeitos de teste - em geral estudantes - não conseguem entender os limites e as diferenças entre machucar e matar uma pessoa. Com isso, os autores levantam o seguinte questionamento: será que alguém que esbraveja e demonstra agressividade imediata, após perder em um jogo, tem a mesma malícia que um homicida? ${ }^{49}$ Oportunamente, há que se indagar: o que é o "excesso" de violência? Afinal, se considerarmos que qualquer nível de violência é prejudicial, a esmagadora maioria dos pré-adolescentes e adolescentes seria considerada anormal, o que não se mostra razoável. Assim, estabelecer um padrão de violência considerado "normal" é o pressuposto para a medição dos excessos, o que ainda não foi feito. ${ }^{50}$

Ainda no campo da metodologia, os autores trazem um último ponto que merece consideração, denominado "problema da gaveta". O que acontece é que as pesquisas publicadas nos jornais científicos não representam a totalidade dos estudos sobre os jogos eletrônicos, uma vez que os estudos que falham em achar resultados estatisticamente significativos têm uma probabilidade menor de serem aceitos para publicação. Destarte, os que são publicados representam apenas uma fração

\footnotetext{
${ }^{48}$ Ibid. p.55.

${ }^{49}$ Ibid. p.65.

${ }^{50}$ Ibid. p. 71.
} 
desconhecida de todas as pesquisas, e tendem a ser justamente aqueles que demonstram correlações positivas entre os jogos e a violência. ${ }^{51}$

Ao adentrarem o cerne da questão, Kutner e Olson afirmam ser ainda incerto se os jogos violentos inspiram as crianças a agirem de maneira violenta, se as crianças que buscam esses jogos são justamente as que já possuíam um comportamento violento pré-existente ou se existe algum outro tipo de relação entre esses fatores. Nada obstante, a pesquisa conduzida por eles revelou que as crianças reconheciam a diferença entre o real e o virtual, e que os pais não deveriam ficar preocupados com o impacto dos jogos violentos na formação dos seus filhos, já que as crianças entrevistadas demonstraram ter absorvido bem os valores que lhes foram transmitidos em casa.

Com efeito, os autores explicam que os pais se encontram hoje confusos e preocupados com esses jogos, o que é absolutamente compreensível, tendo em vista que essa é a primeira geração de genitores a lidar com o desafio. Por conta disso, muitas vezes esses pais pecam ao restringir inadvertidamente o acesso dos seus filhos aos jogos eletrônicos, ao invés de dar as instruções necessárias para que eles lidem com esse tipo de informação, que lhes será transmitida inevitavelmente, seja através da televisão ou jogando os famigerados jogos na casa de um amigo. Consequentemente, os autores defendem que os pais devem conhecer melhor os seus filhos e enxergar além do videogame, buscando solucionar os verdadeiros problemas da criança, caso eles existam. Por essa lógica, focar nos jogos eletrônicos, quando a criança apresenta questões subjacentes a serem tratadas, é uma grande distração que pode contribuir para a ocorrência de tragédias. Em síntese: os jogos eletrônicos devem ser tratados mais como um sinal de alerta do que como a verdadeira causa de problemas.

Dessa forma, é possível perceber que os pilares das decisões brasileiras não são tão sólidos quanto parecem, nem representam um

\footnotetext{
${ }^{51}$ Ibid. p.81-82.
} 
consenso que justifique o tratamento dogmático recebido. Sendo assim, uma vez comprovada a heterogeneidade do seu público alvo e a pluralidade de pesquisas e argumentos sobre seus efeitos, a discussão sobre os limites dos jogos eletrônicos deve ser levada para outro patamar, no qual se fará uma análise de mérito mais profunda.

\subsection{Os jogos eletrônicos e os outros tipos de mídia}

Uma vez expostos os pontos fracos das decisões proibitivas, cabe agora traçarmos um paralelo entre os jogos eletrônicos e os outros tipos de mídia, de forma a avaliarmos se existe algum elemento, na sua própria natureza, que justifique um tratamento diferenciado.

Em um rápido contraste com os outros meios, a característica dos jogos eletrônicos que salta aos olhos é a sua interatividade. De acordo com Ronaldo Lemos, "é justamente por conta de preconcepções quanto aos efeitos da 'interatividade' que os jogos costumam ser tratados diferentemente dos filmes ou dos livros". 52 Assim, ao assumirmos essa constatação como verdadeira, a questão passa a ser analisar o papel da interatividade nos jogos eletrônicos e avaliar, até que ponto, a mesma representa uma ameaça.

Como evidenciamos no Capítulo I, os jogos eletrônicos da presente geração apresentam, junto com seu elevado grau de realismo, um nível de interação que supera o de qualquer outra forma de mídia. Não fosse o crescente nível de interação suficiente, é cada vez maior o número de jogos que apresentam uma grande liberdade de narrativa, o que permite que os jogadores explorem o jogo no seu próprio ritmo e ordem de preferência, assim como desenvolvam atividades paralelas não necessariamente ligadas à história principal. Como bons exemplos dessa liberdade, é possível citar os títulos Grand Theft Auto IV e Red Dead Rendemption, produzidos pela

\footnotetext{
${ }^{52}$ LEMOS, Ronaldo. Games incomodam e viram arte. Disponível em $\langle$ http://www.culturalivre.org.br/index.php?Itemid=40\&id=328\&option=com content\&task=view $>$ Acesso em 28 de outubro de 2010.
} 
polêmica empresa Rockstar, e as duas sequências da série Dead Rising, desenvolvidas pela empresa Capcom. Em todas essas obras, o jogador imerge em um mundo virtual criado com tanta riqueza de detalhes e episódios "paralelos" que fazem com que até mesmo a narrativa principal assuma o papel de coadjuvante. Nessas condições, enquanto os antigos jogos, de estrutura linear, possuíam um tempo de conclusão estimado, essa nova linha de jogos "livres" é marcada por uma imprevisibilidade de trajetória e tempo de conclusão, que variam conforme as escolhas feitas pelo jogador.

Paralelamente, outra característica que tem sido verificada com maior freqüência é a possibilidade de "personalização" do ambiente e dos personagens dos jogos eletrônicos. Através desse recurso, os jogadores passaram a ter a liberdade de alterar alguns elementos pré-definidos do jogo, no intuito de melhor adequá-los ao seu perfil, realidade ou gostos. A aposta dos criadores, com esse tipo de tecnologia, é aumentar a identificação entre o jogador e o protagonista, o que invariavelmente reforça a atratividade da obra. É assim que jogos como Mass Effect, da empresa Bioware, permitem a completa edição da aparência do personagem principal, abrangendo elementos como sexo, estrutura facial, cor da pele, cor dos olhos, tipo de cabelo, alinhamento do maxilar, forma do nariz, dentre outros caracteres. Ainda nessa esteira, há jogos que permitem a edição de cenários e modificações de conteúdos, tais como a aclamada série Halo e o popular The Sims, que nada mais é que um "simulador" da vida humana. Aproveitando o ensejo, faz-se necessário salientar que o jogo Countersrike, objeto de proibição judicial no Brasil, surgiu justamente de uma modificação do jogo Half-Life, desenvolvido pela empresa Valve Software, assim como também são modificações os cenários que representam combates em favelas cariocas.

Por esse enfoque, se compararmos os jogos eletrônicos com sua mídia mais próxima, os filmes, fica claro que esses carecem da poderosa ferramenta de interatividade daqueles, a qual se apresenta como um recurso 
"extra" que potencializa o processo catártico. Apesar disso, a falta desse elemento não justifica que os filmes sejam vistos como mera forma de entretenimento, enquanto os jogos são taxados como "simuladores de crimes". Fazer isso é subestimar o poder da dramaturgia, a qual é responsável por fomentar sentimentos como raiva, ansiedade e medo há mais de séculos.

Apesar da interatividade ser encarada como um problema, existem grandes benefícios associados ao seu uso. Em um primeiro momento, é possível citar diversos estudos que atestam os ganhos provenientes da interação via jogos eletrônicos, como a melhora na vida social de adolescentes $^{53}$, ou seu uso terapêutico ${ }^{54}$ e preventivo $^{55}$. Há pesquisas, inclusive, que sustentam que os jogos violentos seriam extremamente benéficos para o cérebro ${ }^{56}$. Adicionalmente, a interatividade é a chave mestra de um aspecto bastante positivo dos jogos eletrônicos, denominado “Aprendizado Tangencial”. De acordo com Arthur Protasio:

\begin{abstract}
Ainda em referência ao aspecto cultural dos jogos, através dos seus benefícios como ferramenta, vale destacar o conceito de "Aprendizado Tangencial" introduzido por James Portnow [2008]. Trata-se da noção de expor conhecimento ao jogador em vez de efetivamente tentar ensiná-lo. Apresentando ao jogador a oportunidade de se aprofundar nos temas aos quais já encontra-se em exposição em função da própria narrativa ou gameplay do jogo. Assim, cria-se uma experiência não fundamentada na educação, mas na facilitação do aprendizado, permitindo um engajamento maior com a iniciativa autodidata e sem remover o elemento de diversão inerente aos jogos. Torna-se possível definir o aprendizado tangencial como o ato de auto-educação de um jogador que se envolve com um material, no caso um jogo eletrônico, que lhe é envolvente e ofereça um contexto
\end{abstract}

\footnotetext{
${ }^{53}$ TERRA. Estudo: videogame pode melhorar vida social de adolescentes. Disponível em $<$ http://noticias.terra.com.br/ciencia/noticias/0,,OI3189556-EI8147,00-

Estudo+videogame+pode+melhorar+vida+social+de+adolescentes.html > Acesso em 28 de outubro de 2010.

${ }^{54}$ G1 - CIÊNCIA E SAÚDE. Jogar Tetris ajuda a reduzir estresse pós-traumático, diz estudo. Disponível em <http://g1.globo.com/Noticias/Ciencia/0,MUL946771-5603,00JOGAR+TETRIS+AJUDA+A+REDUZIR+ESTRESSE+POSTRAUMATICO+DIZ+ESTUDO.ht ml> Acesso em 28 de outubro de 2010.

${ }^{55} \mathrm{O}$ GLOBO - SAÚDE. Videogames podem ajudar a proteger o cérebro do envelhecimento precoce, indica estudo. Disponível em <http://oglobo.globo.com/vivermelhor/mat/2008/12/22/videogames-podem-ajudar-protegercerebro-do-envelhecimento-precoce-indica-estudo-587508681.asp $>$ Acesso em 28 de outubro de 2010.

${ }^{56}$ FERREIRA, Carlos Eduardo Dias. Pesquisa afirma que jogos violentos podem ser benéficos para o raciocínio. Disponível em <http://www.baixakijogos.com.br/noticias/8509> Acesso em 28 de outubro de 2010.
} 
de maior engajamento em relação a tópicos que sejam de interesse do próprio usuário. Geralmente as temáticas e narrativas dos jogos são as mais eficazes ferramentas de aprendizado tangencial, seja porque certo jogador optou por pesquisar as campanhas da Segunda Guerra Mundial após jogar a Medal of Honor (Electronic Arts, 1999) seja porque se interessou pela disputa das famílias romanas Julius, Scipio e Brutus em Rome Total War (Creative Assembly, 2004) ou descobriu que o termo "fallout" não é só um título, mas na realidade a dissipação de radiação residual causada por partículas que caem após uma explosão nuclear. $\mathrm{O}$ aprendizado tangencial tem se revelado como um método útil de aplicação de conhecimento, tradicional ou não, em função do envolvimento proporcionado pela mecânica de jogo. Trata-se de uma incorporação voluntária dos símbolos, regras e costumes oferecidos nos jogos, ou seja, uma adequação cultural sem que a questão da educação atue como um elemento de interferência. ${ }^{57}$

Graças a esse mecanismo, até mesmo jogos com conteúdo violentos podem ser uma forma inteligente de instigar a curiosidade ou a reflexão sobre determinados temas. Como bom exemplo, é possível citar o jogo Assassin's Creed, que apesar de ser repleto de cenas violentas, retrata a história dos Cavaleiros Templários e da Terceira Cruzada, ocorrida em 1191. Outra boa referência é o jogo God of War III, da empresa Sony Santa Monica, que retrata personagens do mundo da mitologia grega, a despeito da violência inerente ao próprio título. Nesse contexto, não é à toa que as universidades americanas estão começando a explorar essa ferramenta dos jogos eletrônicos, como já ocorre com a University of Florida ${ }^{58}$ e a Wabash College $^{59}$. O Brasil, a seu turno, também possui títulos que se encaixam nessa categoria. Entre eles, destaca-se o jogo Capoeira Legends: Path to Freedom, da desenvolvedora brasileira Donsoft Entertainment, que retrata a história da luta de origem negra no Rio de Janeiro de $1828 .^{60}$

Conforme demonstrado, ainda inexiste consenso entre os psicólogos quanto aos efeitos dos jogos eletrônicos. Em razão disso, ainda não

\footnotetext{
${ }^{57}$ PROTASIO, Arthur. Games e Liberdade de Expressão. p.7-8.

${ }^{58}$ O GLOBO - TECNOLOGIA. "StarCraft" vira tema de curso em faculdade nos EUA. Disponível em <http://oglobo.globo.com/tecnologia/mat/2010/08/25/starcraft-vira-tema-de-cursoem-faculdade-nos-eua-917471626.asp> Acesso em 28 de outubro de 2010.

${ }^{59}$ Id. "Portal", jogo da Valve, vira referência em matéria de faculdade americana. Disponível em <http://oglobo.globo.com/tecnologia/mat/2010/08/23/portal-jogo-da-valve-vira-referencia-emmateria-de-faculdade-americana-917455309.asp> Acesso em 28 de outubro de 2010.

${ }^{60}$ MACHADO, André. Jogos de guerra podem ser fonte de aprendizado, diz pesquisador. Disponível em <http://oglobo.globo.com/tecnologia/mat/2009/12/14/jogos-de-guerra-podem-serfonte-de-aprendizado-diz-pesquisador-915188696.asp $>$ Acesso em 28 de outubro de 2010.
} 
podemos afirmar, com completa segurança, que os jogos violentos são inofensivos à formação dos mais jovens. Ainda assim, o que não se pode ignorar é que existem outras mídias retratando conteúdos semelhantes, tais como os filmes ou as novelas, as quais não geram tanta preocupação dos pais ou ingerências tão repressivas do Estado. Ao mesmo tempo, é preciso levar em consideração os diversos aspectos positivos da interatividade dos jogos, os quais acabam sendo, por muitas vezes, negligenciados.

É através da interatividade que o jogador tem a opção de escolher qual caminho seguir, quais decisões tomar. Por conseguinte, inúmeros são os jogos que permitem ao jogador escolher qual será o destino do personagem, seja ele "bom" ou "mau", sendo demonstradas, em seguida, as conseqüências dessas escolhas. Como exemplo, podemos citar o jogo Black \& White, da empresa Lionhead Studios, no qual o jogador deve escolher entre ser um Deus bom ou mal, lidando com as conseqüências que advém da sua preferência. Em outros, o jogador é colocado em situações que o obrigam a enfrentar dilemas morais, a tomar decisões difíceis, tais como as do mundo real, fazendo com que ele tenha a oportunidade de experimentar, em um ambiente simulado, a forma como suas ações influenciam seu entorno $^{61}$. Olhando por essa perspectiva, a interatividade dos jogos se mostra como uma excelente ferramenta de aprendizado, permitindo a autoreflexão do jogador mais maduro (destinatário original desse gênero de jogos) ou a interação entre pais e filhos sobre temas importantes.

É inegável que existe uma discriminação no que se refere aos jogos eletrônicos. Ainda que alguns sustentem que não há tratamento diferenciado, mas sim um controle de excessos, basta uma simples comparação entre os jogos proibidos no Brasil e a realidade dos cinemas para perceber que há uma falta de isonomia entre os dois gêneros. Pela

\footnotetext{
61 Como bom exemplo dessa interatividade, é possível citar o jogo Heavy Rain, lançado pela empresa francesa Quantic Dreams, em 2010. Nesse título, enquadrado na categoria de drama interativo, as decisões do jogador e as ações realizadas durante o jogo afetam a trama significativamente, sendo possível até mesmo a morte dos protagonistas ainda no decorrer da narrativa. Dessa forma, por conta dos diversos caminhos que a história pode tomar, o jogo possui 18 finais diferentes.
} 
lógica atual, a sociedade que condena o jogo Counterstrike é a mesma que vai aos cinemas assistir ao filme "Tropa de Elite 2" e faz do mesmo um sucesso de bilheteria ${ }^{62}$, desconsiderando o fato de que as duas obras retratam violências semelhantes (mas com um grau muito mais acentuado no cinema). De forma mais alarmante, não há justificativa que explique por que títulos como Mortal Kombat e Doom não podem ser comercializados como jogos, mas podem ser adaptados para o cinema (filmes de 1995 e 2005, respectivamente). Percebe-se, desse modo, que os jogos eletrônicos são o único tipo de mídia onde impera a ditadura do politicamente correto, na qual representações de cenas exaustivamente transmitidas em outros meios podem ser consideradas inadequadas ou excessivas, o que, por sua vez, passa a produzir cenários peculiares, quiçá paradoxais, nos quais um mesmo título pode ser lançado para o cinema e para os jogos eletrônicos, sendo considerado apropriado no primeiro, mas inapropriado no segundo.

Portanto, desmistificar a questão da interatividade dos jogos mostrase uma tarefa essencial para o futuro dessa mídia eletrônica, principalmente se considerarmos que os próximos anos serão marcados por lançamentos cada vez mais interativos. Apenas para ilustrar, a empresa Microsoft acaba de lançar um acessório para o videogame Xbox 360 que pretende revolucionar a interação no mundo dos jogos eletrônicos. Trata-se do aparelho "Kinect", responsável por transmitir os comandos do jogador não mais por um controle, mas sim através da leitura corporal ${ }^{63}$. Dessa forma, se a interatividade se mostra como um problema hoje, por certo se agravará em breve, quando o próprio jogador passar a encenar os atos violentos.

\footnotetext{
${ }^{62}$ FONSECA, Rodrigo. 'Tropa de elite 2' já é maior bilheteria de estréia do cinema nacional depois da Retomada. Disponível em <http://oglobo.globo.com/cultura/mat/2010/10/10/tropa-deelite-2-ja-maior-bilheteria-de-estreia-do-cinema-nacional-depois-da-retomada-922759130.asp> Acesso em 28 de outubro de 2010.

${ }^{63}$ XBOX - BRASIL. Apresentando Kinect para Xbox 360. Disponível em $\langle$ http://www.xbox.com/pt-BR/kinect/\#> Acesso em 28 de outubro de 2010.
} 


\subsection{Vícios das medidas proibitivas}

Não podemos ignorar o fato de que a proibição aos jogos eletrônicos mostra-se como uma solução incoerente dentro de um Estado democrático que privilegia o pluralismo e a livre expressão. Além de ser uma figura estranha ao ordenamento pátrio, a solução proposta padece ainda de dois grandes vícios: ineficiência e inconstitucionalidade.

Sua ineficiência é marcada por diversos fatores. Em primeiro lugar, porque produz o efeito contrário ao que busca, já que nenhum jogo alcança tanta popularidade quanto aqueles que são reputados proibidos, os quais logo se difundem pela internet ou pelos mercados populares do nosso país $^{64}$. Banir um jogo significa, então, aceitar sua marginalização, estimular a venda no mercado ilegal e a distribuição pela internet, desestimular o comércio legítimo dos jogos eletrônicos no Brasil e aumentar a dificuldade dos pais em controlar o conteúdo acessado pelos seus filhos. Não fosse isso o bastante, a lentidão do nosso sistema judiciário faz com que estejamos discutindo hoje, em 2010, jogos que foram vendidos em 1993, como Doom, o qual está ultrapassado e fora de mercado há mais de década (sua produtora, inclusive, já disponibilizou para os usuários de internet o código de programação do jogo $^{65}$ ). Dessa feita, tal situação configura uma movimentação desnecessária da máquina do Judiciário, com o correspondente dispêndio de verbas públicas, para resolver uma questão inócua, de jogos que já caíram em completo desuso ou abandono, o que chega ao limiar da perda de objeto. Assim, fica evidente que o Poder Judiciário não consegue acompanhar a rápida evolução do mundo dos jogos

\footnotetext{
${ }^{64}$ É o que também afirma Mariscal: "Os jogos eletrônicos, por sua vez, são uma mídia que não é somente voltada para o público infantil, mas também para os adultos. Decisões que os proíbam e mandem apreendê-los em todos os seus locais de comercialização são inadequadas, já que com o advento da internet podem ser encontrados em qualquer website, além de serem contrárias à liberdade de expressão."

MARISCAL, Valéria Gerber. A violência nos meios de comunicação, a proteção da criança e do adolescente e o direito fundamental à liberdade de expressão. Disponível em $<$ http://www.pucrio.br/ensinopesq/ccpg/pibic/relatorio resumo2009/relatorio/dir/valeria.pdf $>$ Acesso em $28 \mathrm{de}$ outubro de 2010. p.18.

${ }^{65}$ ZEROZEN, Games \& Violência. Disponível em

$<$ http://www.zerozen.com.br/games/games\&violencia.htm> Acesso em 28 de outubro de 2010.
} 
(e nem deveria, sob pena de séria violação ao princípio do devido processo legal), o que corrobora a ineficiência dessas medidas proibitivas. Ademais, focar em medidas repressivas, ao invés de preventivas, traz o problema já mencionado pelos autores anteriormente citados: a preocupação em tratar os sintomas, e não as causas. Ao desviarmos o foco dos assuntos que são merecedores de debate, simplesmente escondemos aquilo que é considerado desagradável ou assustador, sem efetivamente resolver nada. Portanto, proibir os jogos violentos, acreditando que o problema está resolvido, não passa de mera ilusão, a qual se mostra potencialmente mais nociva do que a exposição em si, já que priva os mais novos de uma educação necessária para enfrentar o mundo adulto. No mesmo sentido, afirma Vaneigem:

Proteger não é sujeitar. A verdadeira proteção é o desejo e a arte de emancipar de toda proteção. Decididamente a criança tem necessidade de uma proteção que a guarde dos perigos que ela ignora, guie seus passos incertos, traga para seu aprendizado da vida o apoio afetivo indispensável ao sentido humano que se deseja desenvolver nela. Contudo, o verdadeiro cuidado tutelar consiste em lhe fornecer os meios de ela mesma se proteger, em ensinar-lhe uma autonomia bastante vigorosa para equipá-la contra as tentativas de suborno, do domínio da força opressiva, dos subterfúgios que induzem à dependência. Até o momento, a educação familiar e escolar se isolaram no extremo oposto de tal disposição. ${ }^{66}$

Em paralelo à sua ineficácia, é inegável que a proibição dos jogos eletrônicos se apresenta como uma medida eivada de inconstitucionalidade. Primeiramente, porque afronta diretamente o art. $5^{\circ}$, em seus incisos IV e IX, e o art. 220, caput e parágrafo segundo, ambos da Constituição Federal, que estatuem:

Art. $5^{\circ}$ Todos são iguais perante a lei, sem distinção de qualquer natureza, garantindo-se aos brasileiros e aos estrangeiros residentes no País a inviolabilidade do direito à vida, à liberdade, à igualdade, à segurança e à propriedade, nos termos seguintes:

IV - é livre a manifestação do pensamento, sendo vedado o anonimato;

IX - é livre a expressão da atividade intelectual, artística, científica e de comunicação, independentemente de censura ou licença;

\footnotetext{
${ }^{66}$ VANEIGEM, Raoul. Nada é sagrado, tudo pode ser dito: reflexões sobre a liberdade de expressão. São Paulo: Parábola Editorial, 2004. p.87.
} 
Art. 220. A manifestação do pensamento, a criação, a expressão e a informação, sob qualquer forma, processo ou veículo não sofrerão qualquer restrição, observado o disposto nesta Constituição.

$\S 2^{\circ}$ - É vedada toda e qualquer censura de natureza política, ideológica e artística.

Conforme já assentado pelo STJ, em voto proferido pela ministra Nancy Andrighi, "censurar é limitar o direito à liberdade de expressão, é determinar o que deve ser, ou não deve ser dito" ${ }^{, 67}$. Do mesmo modo, a desembargadora federal Selena Maria de Almeida, do Tribunal Regional Federal da $1^{a}$ Região, afirmou que "há de se falar em censura, com verdadeira violação do disposto no art. 220, § 2. , da Constituição Federal, quando o Poder Público interfere no conteúdo da obra que está sendo veiculada." ${ }^{68}$ Assim, frente a esses argumentos, fica nítida a configuração da censura quando falamos da proibição dos jogos eletrônicos.

Além disso, como bem demonstrado previamente, estamos diante de uma colisão entre valores considerados fundamentais, esses entendidos como a liberdade de expressão e a proteção integral à criança e o adolescente. Por conseguinte, na falta de uma hierarquia entre esses valores, torna-se imperativo a aplicação do princípio da proporcionalidade, de modo a preservar, no mínimo, o núcleo essencial de cada um desses direitos. Todavia, em todos os casos observados até hoje, os magistrados se anteciparam à fase de ponderação, supervalorizando a proteção de crianças e adolescentes em detrimento da liberdade de expressão. Um dos julgadores é inclusive categórico ao afirmar que o "princípio constitucional do amparo à criança e ao adolescente é de maior relevância que o da garantia à liberdade de manifestação do pensamento"69. Em que pese o

\footnotetext{
${ }^{67}$ Superior Tribunal de Justiça, acórdão em recurso especial de no 636021/RJ, Terceira Turma, Rel. Ministra Nancy Andrighi. publicado em 06 de março de 2009.

${ }^{68}$ Tribunal Regional Federal da $1^{\mathrm{a}}$ Região, acórdão de n ${ }^{\circ}$ 2003.30.00.002600-0, Relatora Desembargadora Selena Maria de Almeida, publicado em 30 de julho de 2010.

${ }^{69} 19^{\mathrm{a}}$ Vara Federal da Seção Judiciária de Minas Gerais, sentença em ação civil pública de $\mathrm{n}^{\circ}$ 2006.38.00.014197-6, Juiz João César Otoni de Matos, Minas Gerais, publicado em 27 de maio de 2010.
} 
entendimento do magistrado ${ }^{70}$, tal construção não parece ser necessária se atentarmos para a fase que antecede à ponderação. Como é cediço, o Supremo Tribunal Federal adota o exame de proporcionalidade para resolver casos de colidência entre direitos fundamentais, o qual é composto das seguintes etapas: adequação, necessidade e proporcionalidade em sentido estrito ${ }^{71}$. Sendo assim, em um primeiro momento, é necessário verificar se existe uma adequação entre fins legítimos e meios adequados, ou seja, se há um nexo causal entre o ato praticado e o efeito que se busca. Em seguida, passa-se para a fase da necessidade, na qual deve o magistrado questionar se a restrição ao direito fundamental é efetivamente necessária, ou seja, se não existe uma alternativa menos restritiva ao direito fundamental em questão para resolver o conflito. Por fim, e apenas quando superadas essas preliminares, deve ser realizada a efetiva ponderação entre os valores, oportunidade em que o magistrado deve verificar se compensa restringir determinado direito, considerando o que se busca preservar.

Frente a essas considerações, apliquemos o exame da proporcionalidade ao caso concreto. Há adequação entre um fim legítimo e um meio adequado? É possível dizer que sim, já que ninguém questiona a legitimidade do resguardo de crianças e adolescentes, sendo possível interpretar, de modo conivente, que a proibição da comercialização dos jogos atinge o fim pretendido, apesar da exposição já realizada sobre a ineficácia da medida. Nada obstante, ainda que passe dessa etapa, a proibição dos jogos eletrônicos não sobrevive à segunda fase. Isso porque a mesma, em sua essência, suprime a liberdade de expressão em seu núcleo

\footnotetext{
${ }^{70}$ O professor Luís Roberto Barroso, por sua vez, expõe uma visão diversa: "É certo que alguns autores têm admitido a existência de uma hierarquia axiológica, pela qual determinadas normas influenciariam o sentido e o alcance de outras, independentemente de uma superioridade formal. Aqui, todavia, esta questão não se põe. É que os direitos fundamentais entre si não apenas têm o mesmo status jurídico como também ocupam o mesmo patamar axiológico. No caso brasileiro, desfrutam todos da condição de cláusulas pétreas." BARROSO, Luís Roberto. Colisão entre liberdade de expressão e direitos da personalidade. Critérios de ponderação. Interpretação constitucionalmente adequada do Código Civil e da Lei de Imprensa. Disponível em $<$ http://www.migalhas.com.br/arquivo_artigo/art 03-10-01.htm> Acesso em 28 de outubro de 2010 .

${ }^{71}$ Tal como utilizado no julgamento do STF, RE 349703, Relator Min. Carlos Britto, publicado em 05 de junho de 2009.
} 
essencial, ao proibir os jogos de maneira ampla e irrestrita, desconsiderando a existência de uma alternativa menos restritiva: a combinação da Classificação Indicativa com o poder familiar, como será visto mais adiante.

\subsection{Proposições normativas: uma prévia dos precedentes americanos}

Feitas as devidas considerações quanto às decisões judiciais e administrativas, passemos agora ao estudo das propostas legislativas que, apesar da sua latência, são ameaças reais que possuem um potencial restritivo muito maior.

Sejam os projetos de lei "pró-proibição" ou "pró-restrição", fato é que poucos foram aqueles que abordaram alguns pontos delicados da regulação, tais como a dificuldade de determinar o que se entende por "violento" ou "contrário à moral", a existência de uma Classificação Indicativa dessa mídia e a violação da liberdade de expressão do público adulto. Não obstante, até mesmo aqueles que trataram desses temas não o fizeram de forma satisfatória. É o que se verifica, nas seguintes passagens:

Evidentemente o ideal seria que se abolisse tão malfazejo lazer do nosso meio;
mas aos adultos, que já têm, ou deveriam ter, maior senso crítico, não seria
adequado vedar, pura e simplesmente, o acesso a jogos que são censurados para
menores.
Então cumpre não misturar o atendimento (sic): jogos comuns que não sofrem
restrições serão acessíveis a todos; jogos que exponham o uso de arma de
qualquer espécie, técnica de treinamento para matar e sexo explícito serão
acessíveis, em local separado, comprovada a maioridade do interessado.
No
No tocante aos direitos e às garantias fundamentais, é cediço o princípio
constitucional da liberdade de expressão, consagrado nos incisos IV e IX do art.
$5^{\circ}$. No entanto, cumpre-nos destacar que a tipificação do crime ora proposta
resulta do desrespeito ao princípio da liberdade de crença religiosa assegurada
nos incisos IV e VIII do referido artigo, bem como à inviolabilidade da honra e

\footnotetext{
${ }^{72}$ Projeto de lei $\mathrm{n}^{\circ}$ 6868/2006, de autoria da dept. federal Laura Carneiro, apresentado em 05 de abril de 2006.
} 
da imagem das pessoas (inciso X) e à norma que manda punir qualquer discriminação contra os direitos e liberdades fundamentais (inciso XLI). ${ }^{73}$

Embora sejam classificados pelo Ministério da Justiça, alguns jogos de videogame desprezam, notadamente, o comportamento correto das crianças, ensinando palavrões. Em outros, os "gays" são mortos e as religiões, tais como o satanismo, budismo, hinduísmo, judaísmo e o cristianismo, são ofendidas.

Sobre o cristianismo, vê-se em alguns jogos alguém bater em anjos, enquanto se escuta um coral católico. É comum um superbandido bater asas pelo inferno antes da batalha final, ou até derrotar Jesus e seus doze apóstolos, embora tenham nomes engraçados.

(...)

É certo que a $\mathrm{CF}$, no art. $5^{\circ}, \mathrm{XLI}$, dispõe que "a lei punirá qualquer discriminação atentatória dos direitos e liberdades". Assim, entendemos que a liberdade de expressão dos videogames não pode ser confundida com anarquia, desrespeito à imagem e honra das pessoas e aos cultos e suas liturgias. ${ }^{74}$

Foi apenas no exame realizado pela Comissão de Constituição e Justiça e de Cidadania, no projeto de lei de $\mathrm{n}^{\mathrm{o}} 2.566 / 00$, que vislumbramos um esboço de apreciação mais cuidadosa da matéria. Segundo a relatora, Sandra Rosado:

No mérito, penso que o conteúdo da proposta não é adequado nos termos em que foi posto. O PL 2.566/00 veda o "acesso de adolescente menos de dezesseis anos a jogos eletrônicos que incentivem qualquer tipo de violência" (...)

Ora, todos esses tipos estão excessivamente abertos. O que é que incentiva a violência? A morte, um ferimento, presença ou ausência de sangue, tiros em objetos, em animais ou uma mera perseguição poderia também ser considerada violência? Quem é que vai decidir o que é violento? O fiscal? E o comerciante? Vai ficar à mercê do que entender o fiscal?

A meu ver, como é patente a necessidade de impor alguma forma de controle a esses jogos, melhor que se atribuísse, como faz o art. 254 do ECA, a necessidade de que fossem os tais jogos submetidos a uma classificação prévia. ${ }^{75}$

Enquanto esses projetos de lei ainda se encontram em tramitação, mostra-se prudente estudar alguns precedentes dos EUA, que já foram alvo, inclusive, de debates judiciais.

Mesmo sendo um país com forte tradição constitucional libertária, nem mesmo os EUA conseguiram fugir ao ímpeto de regular o conteúdo

\footnotetext{
${ }^{73}$ Projeto de lei ${ }^{\circ}$ 170/06, de autoria do senador Valdir Raupp, apresentado em 30 de maio de 2006.

${ }^{74}$ Parecer da Comissão de Educação, Cultura e Esporte sobre o projeto de lei 170/06, aprovado em 01 de dezembro de 2009.

${ }^{75}$ Parecer da Comissão de Constituição e Justiça e de Cidadania sobre o projeto de lei no $2.566 / 00$, de autoria do dept. federal Nilson Mourão, apresentado em 14 de março de 2000.
} 
dos jogos eletrônicos. Assim, como já destacado anteriormente, o ano de 1993 foi marcado por diversos debates sobre a violência dos jogos no Congresso americano, nos quais títulos como Doom e Mortal Kombat foram usados como exemplos da falta de limites. Em resposta, sete líderes da indústria se reuniram em diversas reuniões para criar uma alternativa à intervenção estatal. A solução encontrada foi a criação da Entertainment Software Rating Board (ESRB), um órgão de auto-regulamentação do setor de videogames, que teria como incumbência atribuir a classificação indicativa aos jogos eletrônicos.

Embora a criação da ESRB tenha acalmado o furor e a primeira tentativa de regulação estatal, tal sistema não foi suficiente para impedir que diversos projetos de lei fossem aprovados anos mais tarde, ensejando controvérsias que foram parar nos tribunais americanos. Eis alguns exemplos.

Em março de 2001, a 7th Circuit Court of Appeals julgou o recurso do caso American Amusement Machine Association v. Kendrick, no qual alguns fabricantes de videogames e seus associados de vendas questionaram uma norma do estado de Indianápolis que limitava o acesso de menores à jogos violentos. Como é de tradição americana, a norma definia "violência gráfica" como "a retratação visual, em aparelho de entretenimento, de lesões reais a seres humanos, ou a eles assemelhados, entre as quais se incluem amputação, decapitação, desmembramento, derramamento de sangue, mutilação ou desfiguração." Ainda de acordo com a lei, os estabelecimentos com esse tipo de jogos estariam obrigados a proibir a entrada de menores desacompanhados, a expor advertências quanto ao uso dos jogos e, caso possuíssem mais que cinco aparelhos de videogame, deveriam criar uma seção isolada e fora do alcance visual dos menores para os jogos violentos. Desse modo, frente à restrição imposta, a American Amusement Machine Association ingressou com uma demanda judicial para sustar os efeitos desse diploma legal. 
Em juízo, o magistrado da corte distrital de Indiana concordou com os autores, entendendo que os jogos eletrônicos representam uma forma de expressão a ser amparada pela liberdade de expressão, e que essa garantia constitucional também se estenderia às crianças e adolescentes. Apesar disso, o juiz entendeu que a lei em questão não era inconstitucional, já que se amparava em evidências razoáveis de que a medida protegeria crianças e adolescentes. Para tanto, o magistrado apontou como "evidências razoáveis" alguns estudos psicológicos apresentados pela cidade de Indianápolis, os quais apontavam que a violência na mídia estimulava comportamentos violentos. Assim, por entender que não houve afronta aos direitos constitucionais dos autores, o juiz não analisou os outros requisitos para concessão de medida liminar.

Inconformados, os autores recorreram dessa decisão, que fora analisada pela 7th Circuit Court of Appeals. Por decisão unânime, o tribunal reverteu a decisão de $1^{\mathrm{a}}$ instância, ao declarar que a norma da cidade de Indianápolis era inconstitucional, sendo reafirmado que crianças e adolescentes também estariam amparados pela garantia da liberdade de expressão. Conforme detalhadamente exposto pelo juiz Richard A. Posner, o nexo entre jogos violentos e a violência real deve ser amplamente comprovado, e nunca presumido. Ao se posicionar quanto às pesquisas apresentadas, Posner foi taxativo ao afirmar que os estudos não comprovam que os jogos violentos são mais perigosos ao consumidor ou à segurança do público do que filmes violentos ou outras formas de entretenimento passivo. ${ }^{76}$ Por fim, ao tratar do tema violência, Posner teceu as seguintes considerações:

A violência sempre foi, e continua sendo, um interesse central da humanidade e um tema recorrente, quase que obsessivo das culturas alta e baixa. Ela desperta o interesse das crianças desde a tenra idade, como todos familiarizados com os clássicos contos de fada de Grimm, Andersen e Perrault devem saber. Proteger as

\footnotetext{
76 American Amusement Machine Association, et al. v. Teri Kendrick, et al. 244 F.3d 572 (7th Cir. 2001), cert. denied, 534 U.S. 994 (2001). Disponível em <http://www.firstamendmentcenter.org/PDF/American_Amusement_Machine_Association_v_Ke ndrick.pdf> Acesso em 28 de outubro de 2010.
} 
crianças da exposição a conteúdos ou imagens violentas até os seus 18 anos não seria apenas quixotesco, mas deformador; isso as deixaria não preparadas para lidar com o mundo como conhecemos. ${ }^{77}$

O ano de 2005, por sua vez, foi marcado por uma série de medidas legislativas com o mesmo propósito: restringir a venda ou o acesso de jogos violentos por crianças e adolescentes. Dessa forma, mais de 20 estados americanos encaminharam projetos com essa natureza, visando resguardar os menores dos efeitos perversos da violência na mídia. Nada obstante, em que pese a boa intenção dos legisladores, nenhuma das leis aprovadas conseguiu sobreviver ao embate nos tribunais americanos, oportunidades em que a inconstitucionalidade das medidas foram ressaltadas. ${ }^{78}$

Dentre todas essas leis, certamente a que merece uma análise mais detalhada é a da Califórnia, a qual foi sancionada pelo governador Arnold Schwarzenegger em 07 de Outubro de 2005. Em linhas gerais, a lei do estado da California determinava que a venda ou o aluguel de jogos violentos estaria proibido para menores, sendo entendido como "jogos violentos" aqueles que facultavam ao jogador matar, mutilar, desmembrar ou violentar sexualmente a imagem de um ser humano, desde que: (i) um homem médio, considerando o jogo como um todo, encontrasse apelos aos interesses mórbidos ou desviantes dos menores; (ii) a obra fosse evidentemente ofensiva aos padrões sociais do que se entende adequado para os menores; (iii) a violência fizesse com que o jogo, como um todo, perdesse qualquer valor literário, artístico, político ou científico para os menores; ou então que o jogador pudesse causar sérios danos a seres humanos, ou a figuras assemelhadas, de forma hedionda, cruel ou depravada, envolvendo tortura ou sério abuso físico da vítima. Adicionalmente, a lei tambem impunha uma exigência de rotulagem própria, pela qual jogos definidos como violentos, ao serem importados ou

\footnotetext{
${ }^{77}$ Ibid.

${ }^{78}$ KUTNER, L.; OLSON, C. K. Grand theft childhood: the surprising truth about violent video games and what parents can do. p.201.
} 
comercializados na California, deveriam ganhar um selo específico do estado, indepentemente da classificação já realizada pela ESRB.

Em virtude dessas restrições, a Video Software Dealers Association ingressou com uma demanda judicial em face do Estado da California e do seu governador ${ }^{79}$, de modo a invalidar a lei recém aprovada, que alterava o Código Civil da California nas seções 1746-1746.5.

Em $1^{a}$ instância, os autores obtiveram êxito em seu pleito, tendo o juiz determinado a invalidade da norma através do exame via strict scrutiny (escrutínio estrito). A esse respeito, o escrutínio estrito trata-se de um dos padrões de revisão judicial utilizados pelas cortes americanas quando estão diante de uma hipótese de colidência entre direitos fundamentais. Conforme ensina Eduardo Appio:

A partir do momento em que a Suprema Corte submete uma determinada lei ou ato ao escrutínio estrito (strict scrutiny), o responsável por sua edição terá o grave ônus de comprovar a existência de um interesse público irresistível, bem como que a lei foi estritamente desenhada para atender esse interesse, pois, caso contrário, a lei será julgada inconstitucional.

A Suprema Corte ainda não definiu, de modo claro, os casos em que está presente esse interesse governamental irresistível, mas se sabe que a mera conveniência administrativa não pode ser conceituada como tal. Esse interesse deve ser real $\mathrm{e}$ não especulativo e também deve ter sido um dos motivos determinantes para a edição da lei. Finalmente, importante salientar que, quando a ameaça ao interesse governamental não tiver uma expressão significativa, a classificação não será aceita e a lei, ainda assim, será declarada inconstitucional.

Caso o responsável pela edição da lei ou do ato consiga comprovar a existência de um interesse governamental irresistível, ainda assim terá de demonstrar que o meio escolhido é o mais adequado à proteção desse interesse.

Com esse sentido, se houver um meio menos gravoso do que o estabelecimento de distinções para proteger esse interesse, fica claro que a distinção não serve "sob medida" para o caso (narrowly tailored). Não basta que o meio (distinção) escolhido seja adequado para a proteção do interesse governamental irresistível. Para passar no teste, o meio terá de ser o mais adequado. ${ }^{80}$

Posteriormente, já em segunda instância, o tribunal citou importantes precedentes jurisprudenciais em sua fundamentação, entre eles:

\footnotetext{
${ }^{79}$ Video Software Dealers Association v. Schwarzenegger, 556 F. 3d 950 - Court of Appeals, 9th Circuit 2009. Disponível em <http://www.ca9.uscourts.gov/datastore/opinions/2009/02/20/0716620.pdf $>$ Acesso em 28 de outubro de 2010.

${ }^{80}$ APPIO, Eduardo. Direito das Minorias. $1^{\text {a }}$ ed.. São Paulo: Revista dos Tribunais, 2008. p.243244.
} 
Os menores têm direito a uma parcela significativa de proteção pela $1^{\mathrm{a}}$ Emenda, e apenas em circunstâncias relativamente estreitas e bem definidas pode o governo barrar a disseminação pública de materiais protegidos a eles. - Erznoznik v. City of Jacksonville, 422 U.S. 205, 212-13, 95 S.Ct. 2268, 45 L.Ed.2d 125 (1975).

Regulações baseadas em conteúdo são presumidamente inválidas. - R.A.V. v. City of St. Paul, 505 U.S. 377, 382, 112 S.Ct. 2538, 120 L.Ed.2d 305 (1992)

O Governo pode regular o conteúdo de expressões constitucionalmente protegidas, de modo a assegurar um interesse irresistível, desde que escolha o meio menos restritivo para articular esse interesse. - Reno v. ACLU, 521 U.S. 844, 876-77, 117 S.Ct. 2329, 138 L.Ed.2d $874(1997)^{81}$

Por fim, após uma análise cuidadosa do caso, o tribunal manteve a decisão proferida pela primeira instância, entendendo que a restrição e a rotulagem impostas pela lei eram inconstitucionais. Para tanto, o tribunal expôs os seguintes motivos:

\begin{abstract}
Por se tratar de uma regulação baseada em conteúdo, a lei está sujeita ao escrutínio estrito e é presumidamente inválida. Sob o escrutínio estrito, o Estado não produziu provas significativas que suportem a conclusão legislativa de que video games violentos causam danos psicológicos ou físicos aos menores. Ainda que o fizesse, a lei não serve sob medida para prevenir esses danos, bem como existem medidas menos restritivas de assegurar esses interesses, como o sistema de classificação da ESRB, as campanhas educacionais reforçadas e os mecanismos de controle pelos pais. Finalmente, mesmo que a exigência de rotulagem apenas afete a expressão comercial na forma da embalagem dos jogos, essa previsão constitui uma imposição impermissível, já que tais símbolos não transmitiriam apenas informações fáticas. ${ }^{82}$
\end{abstract}

Tal caso agora aguarda julgamento pela Suprema Corte americana, com as sustentações orais marcadas para o dia 2 de novembro. Nesse ínterim, diversos estudiosos americanos estão debatendo os pontos a serem abordados pela Suprema Corte, que estabelecerá um importante marco para liberdade de expressão nesse tipo de mídia - seja ela contra, ou a favor.

De um lado, aqueles que são favoráveis às restrições sustentam que a lei não proíbe ninguém de jogar esses jogos violentos (adultos ou crianças), mas impede a venda desses títulos para menores. Nessa lógica, se um pai decidir alugar ou comprar algum desses jogos para seus filhos, essa escolha

${ }^{81}$ Ibid.
${ }^{82}$ Ibid. 
será considerada legítima. A proibição de jogos violentos, outrossim, estaria em harmonia com outros tipos de restrições de vendas para menores, como é o caso dos materiais de conteúdo pornográfico, ou da venda de bebidas e cigarros.

Por outro lado, aqueles que concordam com a inconstitucionalidade da lei se baseiam em grande parte dos argumentos já utilizados pelo tribunal americano: a falta de um interesse irresistível do Estado, a existência de meios menos restritivos à liberdade de expressão e a falta de consenso nos estudos psicológicos. Nada obstante, a estudiosa de direito constitucional americano, Julie Hilden, alerta que existe espaço para a Suprema Corte decidir em favor da lei da Califórnia, se assim o quiser, tendo em vista que existem precedentes nos quais à garantia da liberdade de expressão dos menores não foi levada tão a sério ${ }^{83}$. Ainda assim, Hilden espera que a Suprema Corte não crie exceções para a liberdade de expressão e mantenha a inconstitucionalidade da referida lei, frente ao risco de chilling effect ${ }^{84}$ que ela representa.

\footnotetext{
${ }^{83}$ HILDEN, Julie. The Supreme Court's "Violent" Video Games Case: The California Law Should Be Struck Down, But the Court May Well Uphold It. Disponível em <http://writ.news.findlaw.com/hilden/20100510.html> Acesso em 28 de outubro de 2010.

${ }^{84}$ Em linhas gerais, entende-se por chilling effect o efeito silenciador do discurso provocado pelo medo de condenações à posteriori. Nesses casos, os indivíduos ou grupos restringem a expressão de determinados conteúdos, em virtude do receio de serem condenados pelo que estão defendendo ou comercializando. Sendo assim, ao estabelecermos que a expressão é livre, mas sujeita a condenação posterior, cria-se um cenário propício para a auto-censura, no qual a liberdade de expressão fica restringida aos temas considerados seguros.
} 


\section{CAPÍTULO IV: O PAPEL DA CLASSIFICAÇÃO INDICATIVA E DO PODER FAMILIAR}

\subsection{Classificação Indicativa - conceito e função}

A Classificação Indicativa trata-se de uma atividade que, no Brasil ${ }^{85}$, é exercida pelo Ministério da Justiça, e que encontra amparo na Constituição Federal, nos seus artigos 21, inciso XVI, e 220, § $3^{\circ}$, inciso I, e no art. 74 da Lei 8069/1990 (Estatuto da Criança e do Adolescente - ECA). De forma genérica, podemos defini-la como um conjunto de informações sobre o conteúdo de obras audiovisuais e diversões públicas quanto à adequação de horário, local e faixa etária, e que tem como objetivo alertar os pais ou responsáveis sobre a adequação do conteúdo das obras à idade das crianças e adolescentes. No que se refere especificamente aos jogos eletrônicos, o Ministério da Justiça editou, em 14 de julho de 2006, a portaria $\mathrm{n}^{\circ} 1.100$, a qual trouxe uma série de inovações para o sistema, entre elas o acréscimo da classificação de jogos eletrônicos e RPGs, bem como a autorização para que pais e responsáveis permitam o acesso de crianças e adolescentes a qualquer obra ou diversão pública, desde que não classificada como não recomendada para menores de 18 anos. Ao atentarmos para as considerações estabelecidas na referida portaria, percebemos quais os valores que norteiam a atuação do Ministério da Justiça nessa atividade. Entre as premissas elencadas, destacam-se:

a responsabilidade dos pais no exercício do poder familiar, de acordo com os arts. 1.630 e seguintes da Lei $n^{\circ}$ 10.406, de 10 de janeiro de 2002 - Código Civil;

\footnotetext{
${ }^{85}$ Enquanto o sistema brasileiro é pautado pela atuação do Estado, não é essa a realidade compartilhada pelos EUA e pela Europa. Nos EUA, como já destacado, tal tarefa incumbe a ESRB, um órgão de auto-regulamentação de iniciativa privada e de adesão voluntária pelas produtoras de jogos - ainda que, na prática, a vasta maioria adote o sistema. Já a Europa criou o seu sistema unificado de classificação indicativa - o Pegi (Pan-European Game Information) - que foi lançado na primavera de 2003 e substituiu uma série de sistemas de classificação nacionais, sendo hoje adotado em 30 países europeus. Assim como o americano, trata-se de um sistema voluntário, mas que encontra adesão pela grande maioria das produtoras de jogos.
} 
a co-responsabilidade da família, da sociedade e do Estado na garantia à criança e ao adolescente do direito à educação, ao lazer, à cultura e à dignidade, de acordo art. 227 da Constituição Federal;

que o exercício da Classificação Indicativa de forma objetiva, democrática e em co-responsabilidade com a família e a sociedade, implica em outros deveres, entre eles, o dever de divulgar a classificação indicativa com uma informação consistente e de caráter pedagógico, para que os pais realizem o controle da programação; e, ainda, o dever de exibir o produto de acordo com a classificação, como meio legal capaz de garantir à pessoa e à família a possibilidade de se defenderem de produtos inadequados;

a necessidade de serem fixados novos procedimentos em relação à Classificação Indicativa, norma constitucional, cujo procedimento assegura o contraditório e a ampla defesa, vinculada ao direito à liberdade de expressão e ao dever de proteção absoluta à criança e ao adolescente, cuja observância constitui dever da família, sociedade e Estado

Em seguida, seu art. $2^{\circ}$ define a natureza, a finalidade e o alcance da Classificação Indicativa, determinando que a mesma possui natureza informativa e pedagógica, voltada para a promoção dos interesses de crianças e adolescentes, devendo ser exercida de forma democrática, possibilitando que todos os destinatários da recomendação possam participar na condição de interessados do processo, ensejando que a contradição de interesses e argumentos promovam a correção e o controle social dos atos praticados. Adicionalmente, segundo seu art. $5^{\circ}$, o órgão responsável por realizar essa atividade é o Departamento de Justiça, Classificação, Títulos e Qualificação (Dejus), o qual recebe dos distribuidores ou produtores fotos, vídeos, sinopses ou até mesmo jogos demonstrativos, com uma ou mais fases, para que seja efetuada a classificação dos mesmos. Desse modo, consoante seu art. 14, são utilizados os critérios de violência e sexo para inserir os jogos nas seguintes categorias:

I - especialmente recomendada para crianças e adolescentes;

II - livre - para todo o público;

III - não recomendada para menores de 10 (dez) anos;

IV - não recomendada para menores de 12 (doze) anos;

$\mathrm{V}$ - não recomendada para menores de 14 (quatorze) anos;

VI - não recomendada para menores de 16 (dezesseis) anos; e

VII - não recomendada para menores de 18 (dezoito) anos. 
Finalmente, dois outros artigos merecem destaque, pois sintetizam o papel desenvolvido pelo Ministério da Justiça na proteção dos menores. São eles:

Art. 12. A atividade de Classificação Indicativa exercida pelo Ministério da Justiça é meio legal capaz de garantir à pessoa e à família a possibilidade de receber as informações necessárias para se defender de diversões públicas inadequadas à criança e ao adolescente, nos termos da Constituição e da Lei $n^{\circ}$ 8.069, de 13 de julho de 1990 (Estatuto da Criança e Adolescente - ECA).

Art. 18. A informação detalhada sobre o conteúdo da diversão pública e sua respectiva faixa etária é meramente indicativa aos pais e responsáveis que, no regular exercício de sua responsabilidade, podem decidir sobre o acesso de seus filhos, tutelados ou curatelados a obras ou espetáculos cuja classificação indicativa seja superior a sua faixa etária.

\subsection{A função dos pais no controle de conteúdo}

O artigo 1634, inciso I, do Código Civil é claro ao fixar que compete aos pais, quanto à pessoa dos filhos menores, dirigir-lhes a criação e educação. Apesar disso, nenhuma das decisões apresentadas considerou, ou ao menos discutiu, o papel a ser desempenhado pelos pais na seleção de conteúdos apropriados para os seus filhos - o que configura um descaso com a sistemática criada pelo ordenamento pátrio.

Pela simples leitura da norma, percebe-se que o Estado não pode invocar para si uma prerrogativa que pertence aos pais, determinando aquilo que pode ou não ser visto por crianças e adolescentes. Por oportuno, cabe transcrever o entendimento firmado pela ministra Nancy Andrighi sobre a matéria:

Sabe-se que o poder familiar é, em regra, inerente à paternidade. Com base nesse poder, nos termos do art. 1.634 do $\mathrm{CC} 02$, compete aos pais dirigir a criação e educação de seus filhos menores.

Esse poder pode ser visto sob dois ângulos no que diz respeito ao desenvolvimento físico, intelectual, moral e espiritual da criança e do adolescente. Em primeiro lugar, os genitores têm direito de conduzir a educação de seus filhos segundo os preceitos morais, religiosos, científicos e sociais que considerem adequados. Mas, para além de um direito dos pais, a educação dos filhos é um dever que a legislação impõe. O art. 205 da CF/88 estabelece, nesse sentido, que a educação é dever do Estado e da família, devendo visar ao pleno desenvolvimento da pessoa. 
O que importa, de qualquer forma, é que esse poder-dever insere-se no contexto pluralista que rege toda a sociedade brasileira e ampara-se, mais especificamente, nas liberdades de pensamento, de expressão e de culto religioso. O ensino, diznos o art. 206 da CF/88, assenta-se sobre os princípios da "liberdade de aprender, ensinar, pesquisar e divulgar o pensamento, a arte e o saber" e do "pluralismo de idéias e de concepções pedagógicas", entre outros. ${ }^{86}$

Nesse tocante, ninguém melhor do que os próprios pais para determinar o grau de discernimento dos menores e a que tipo de conteúdo eles já podem ter acesso. Não podemos esquecer, outrossim, que dificilmente uma resposta genérica do Estado será tão eficaz quanto o olhar atento da família, já que crianças e adolescentes apresentam características e processos de amadurecimento singulares. Por essa lógica, é possível que um adolescente de 16 anos não tenha a maturidade necessária para ter acesso a determinado conteúdo, normalmente apropriado à sua idade, enquanto outro de 14 já possa acompanhar uma programação um pouco acima da sua faixa etária. Tanto é verdade que, de acordo com o art. 19 da portaria 1.100/2006, editada pelo Ministério da Justiça, os pais ou responsáveis possuem a prerrogativa de autorizar o acesso de suas crianças e/ou adolescentes a diversão ou espetáculo cuja classificação indicativa seja superior à faixa etária destes, porém inferior a 18 (dezoito) anos, desde que acompanhadas por eles ou terceiros expressamente autorizados. Afinal, como assevera o Ministério da Justiça, "a classificação indicativa não é censura e não substitui a decisão da família" ${ }^{87}$, cabendo aos pais decidir quanto ao acesso a entretenimento, informação ou cultura.

Sob esse enfoque, o Estado, ao censurar os jogos eletrônicos, não só assume uma desnecessária figura paternalista, como também usurpa a prerrogativa dos pais em dirigir a educação dos filhos da maneira que lhes melhor convir. No cenário que vislumbramos hoje, por mais incongruente que possa parecer, um pai pode autorizar o filho a ver um filme violento no

\footnotetext{
${ }^{86}$ Superior Tribunal de Justiça, acórdão em recurso especial de no 1072035/RJ, Terceira Turma, Rel. Ministra Nancy Andrighi, publicado em 04 de agosto de 2009.

${ }^{87}$ Ministério da Justiça. Classificação Indicativa: Informação e Liberdade de Escolha. Disponível em: 〈http://www.abmp.org.br/UserFiles/File/cartilha_classificacao_indicativa.pdf $>$. Acesso em 28 de outubro de 2010. p.6.
} 
cinema, obedecidos os requisitos legais, ou até mesmo deixá-lo assistir a séries ou novelas destinadas a um público alvo mais maduro, sem que o Estado se oponha ou condene esse tipo de prática (muito pelo contrário, a legitima, como já expressamente demonstrado). Nada obstante, no que se refere aos jogos eletrônicos, tal prerrogativa não se verifica, pois, a despeito de também existir uma classificação indicativa sobre esse meio (o que deveria permitir os mesmo tipos de escolhas), o Estado entende que deve haver limitação de conteúdo nesses casos.

É certo que, em todos os julgados abordados, o art. 227 da Constituição Federal foi invocado para legitimar a intervenção estatal, em função da co-responsabilidade da família, da sociedade e do Estado na garantia à criança e ao adolescente do direito à educação, ao lazer, à cultura e à dignidade. Nesse caso, todavia, é dever do Estado fornecer os instrumentos para que os pais possam tomar melhores decisões, como a Classificação Indicativa, bem como fiscalizar que jogos adultos não estejam sendo vendidos para menores, tal como é feito com cigarros ou bebidas alcoólicas - produtos esses que sabidamente causam malefícios ao consumidor, mas que nem por isso são proibidos ou retirados do mercado. Agir dessa forma não é o mesmo que tomar as decisões pelos pais, seja por convicções políticas, seja por conveniência econômica. Falar em coresponsabilidade pressupõe a participação não só do Estado, mas também da família e da sociedade, nos moldes já estabelecidos pelo Código Civil e pela Constituição Federal. Desse modo, apostar em uma resposta unilateral estatal não se mostra apenas uma prática abusiva, mas um menosprezo à capacidade dos pais e da sociedade em filtrar as mensagens que lhes são transmitidas. Como assevera Gilmar Mendes:

Não é o Estado que deve estabelecer quais as opiniões que merecem ser tidas como válidas e aceitáveis; essa tarefa cabe, antes, ao público a que essas manifestações se dirigem. Daí a garantia do art. 220 da Constituição brasileira. Estamos, portanto, diante de um direito de índole marcadamente defensiva - 
direito a uma abstenção pelo Estado de uma conduta que interfira sobre a esfera de liberdade do indivíduo. ${ }^{88}$

Corroborando esse raciocínio, cumpre destacar algumas disposições elencadas pela Convenção da ONU sobre os Direitos das Crianças, tratado esse que foi promulgado no Brasil em 21 de novembro de 1990. Entre os artigos que merecem destaque, encontram-se:

\begin{abstract}
ARTIGO 5
Os Estados Partes respeitarão as responsabilidades, os direitos e os deveres dos pais ou, onde for o caso, dos membros da família ampliada ou da comunidade, conforme determinem os costumes locais, dos tutores ou de outras pessoas legalmente responsáveis, de proporcionar à criança instrução e orientação adequadas e acordes com a evolução de sua capacidade no exercício dos direitos reconhecidos na presente Convenção.
\end{abstract}

\begin{abstract}
ARTIGO 13
1. A criança terá direito à liberdade de expressão. Esse direito incluirá a liberdade de procurar, receber e divulgar informações e idéias de todo tipo, independentemente de fronteiras, de forma oral, escrita ou impressa, por meio das artes ou por qualquer outro meio escolhido pela criança.
\end{abstract}

\title{
ARTIGO 14
}

1. Os Estados Partes respeitarão o direito da criança à liberdade de pensamento, de consciência e de crença.

2. Os Estados Partes respeitarão os direitos e deveres dos pais e, se for o caso, dos representantes legais, de orientar a criança com relação ao exercício de seus direitos de maneira acorde com a evolução de sua capacidade.

\begin{abstract}
ARTIGO 18
1. Os Estados Partes envidarão os seus melhores esforços a fim de assegurar o reconhecimento do princípio de que ambos os pais têm obrigações comuns com relação à educação e ao desenvolvimento da criança. Caberá aos pais ou, quando for o caso, aos representantes legais, a responsabilidade primordial pela educação e pelo desenvolvimento da criança. Sua preocupação fundamental visará ao interesse maior da criança.

2. A fim de garantir e promover os direitos enunciados na presente Convenção, os Estados Partes prestarão assistência adequada aos pais e aos representantes legais para o desempenho de suas funções no que tange à educação da criança e assegurarão a criação de instituições, instalações e serviços para o cuidado das crianças.
\end{abstract}

\begin{abstract}
ARTIGO 31
1. Os Estados Partes reconhecem o direito da criança ao descanso e ao lazer, ao divertimento e às atividades recreativas próprias da idade, bem como à livre participação na vida cultural e artística.
\end{abstract}

\footnotetext{
${ }^{88}$ MENDES, Gilmar F. et al. Curso de Direito Constitucional. São Paulo: Saraiva, 2007. p. 351.
} 
Sobre o art. 18, o embaixador e conselheiro especial do governo sueco sobre questões humanitárias, Thomas Hammarberg, faz as seguintes considerações:

\begin{abstract}
A outra referência (art. 18) é sobre o papel dos pais ou tutores legais. Eles têm "a responsabilidade fundamental de criar e formar a criança". O Estado, por sua vez, deve assisti-los em suas responsabilidades na criação das crianças. Este texto reflete a atitude geral da Convenção quanto ao relacionamento triangular entre a criança, seus responsáveis e o Estado: os pais ou outros tutores são de importância-chave para a criança, o Estado deve dar-lhes apoio e apenas em casos excepcionais - nos maiores interesses da criança - tomar posições sobre como as crianças devem ser criadas. Neste contexto a implicação é que os tutores têm uma responsabilidade direta na proteção da criança contra influências prejudiciais da mídia e devem receber apoio nesta tarefa. ${ }^{89}$
\end{abstract}

Sendo assim, após os comentários de Hammarberg sobre a mecânica de responsabilidades cunhada no texto da ONU, fica evidente a sua harmonia com o ordenamento vigente, que privilegia as escolhas feitas pelos pais.

Entender porque crianças e adolescentes são atraídos por conteúdos violentos ainda é uma pergunta sem resposta - e que vai muito além das pretensões desse trabalho. As próprias brincadeiras de luta entre crianças dão sinais de que existe uma forte inclinação humana para esse tema, o qual ainda é objeto de meras especulações pelos estudiosos. A despeito dessa realidade, não se pode olvidar que a mesma tecnologia que traz os problemas, traz consigo, também, a solução. É dessa forma que as plataformas dos mais recentes videogames e dos sistemas operacionais de computadores apresentam um sistema de controle dos pais, o qual permite a inserção de senhas nos aparelhos e a seleção dos jogos conforme a suas classificações indicativas. Consequentemente, cai por terra qualquer questionamento relativo ao controle de conteúdo exercido pelos pais, ainda que esses possuam rotinas atarefadas que os distanciem do cotidiano do menor. O que há, na realidade, é uma subutilização do mecanismo

\footnotetext{
${ }^{89}$ CARLSSON, Ulla et al. A Criança e a Violência na Mídia. Brasília: UNESCO Brasil, 1999. Disponível em <http://unesdoc.unesco.org/images/0013/001308/130873por.pdf $>$ Acesso em $28 \mathrm{de}$ outubro de 2010. p.26.
} 
oferecido pelos fabricantes, que por vezes sequer é conhecido pelos pais. Portanto, investir na conscientização do público, ao invés da proibição de títulos, é a melhor postura a ser adotada pelo Estado.

\subsection{Os desafios da Classificação Indicativa}

Após essa exposição, fica claro por que a Classificação Indicativa mostra-se como uma medida mais adequada para se alcançar o fim proposto, qual seja o de assegurar a proteção integral às crianças e adolescentes, sem com isso restringir o acesso aos jogos eletrônicos pelo restante do público adulto. É ela, inclusive, que permite a efetividade do art. 75 do ECA, que determina que toda criança ou adolescente terá acesso às diversões e espetáculos públicos classificados como adequados à sua faixa etária. No entanto, mesmo sendo uma alternativa constitucionalmente mais adequada, tal sistema não está imune a críticas, nem à necessidade de ulteriores ajustes.

De fato, a Classificação Indicativa ainda possui um longo caminho de aperfeiçoamento, tanto no Brasil como no resto do mundo. A Austrália, por exemplo, sofre com lacunas encontradas em seu próprio sistema, que prevê uma faixa etária máxima de 15 anos para a classificação dos jogos eletrônicos, o que inviabiliza a comercialização de títulos destinados a públicos adultos. Consequentemente, como destaca Arthur Protasio, cria-se uma distorção entre as mídias que priva os jogos de se desenvolverem como ferramenta artística e cultural, o que acaba incentivando a ira popular e a importação de jogos. ${ }^{90}$

Outro exemplo de correção a ser realizada encontra-se na seguinte crítica ao sistema americano, feita por Kutner e Olson:

De acordo com as pesquisas sobre os efeitos da violência na mídia, a ESRB pode ter parte de seu sistema de classificação invertido! Um dos fatores que indicam que as mídias violentas são capazes de produzir comportamentos violentos no

\footnotetext{
${ }^{90}$ PROTASIO, Arthur. Games e Liberdade de Expressão. p.17.
} 
mundo real é a existência de obras que não mostram as consequências negativas reais da violência, tais como dor, sofrimento e sangue. Jogos de videogame violentos que são classificados na categoria $M$ são os mais propensos a mostrar essas conseqüências negativas. Por sua vez, aqueles que são classificados nas categorias $\mathrm{T}$ ou $\mathrm{E}$ conquistam tais avaliações mais baixas em parte por não mostrar essas consequiências negativas: os cadáveres simplesmente desaparecem; o sangue é animado, ao invés de realista. Além disso, os jogos em que o jogador é recompensado com pontos extras por evitar confrontos violentos (por exemplo, a série SWAT) acabam recebendo a mesma classificação $M$ que jogos nos quais o jogador recebe pontos extras por empilhar cadáveres virtuais. ${ }^{91}$

Há, ainda, outras questões que merecem melhor aprofundamento. Uma delas se refere aos jogos amadores desenvolvidos para internet, os quais representam uma realidade cada vez mais presente nesse meio, mas que carece de classificação oficial. Por não se tratarem de produtos comercializados no mercado, existem hoje inúmeros jogos disponíveis para download ou acesso via internet que não possuem nenhuma forma de regulamentação pelo Ministério da Justiça. Ainda que a resposta mais simples seja submeter essas obras ao procedimento de classificação padrão, existem pontos delicados que devem ser observados com parcimônia. Primeiramente, esse tipo de obrigação teria uma dificuldade de aplicação prática, pois esbarraria no grande número de jogos criados diariamente e nos problemas jurídicos de competência e soberania na internet. Em segundo lugar, a submissão desses jogos para avaliação pelo Ministério da Justiça poderia sufocar as iniciativas de cunho independente, devido aos custos inerentes ao procedimento administrativo. Essa é, inclusive, uma problemática que está sendo tratada na Austrália, onde os desenvolvedores de jogos estão questionando a necessidade de submissão prévia de jogos para aparelhos de celular, que lhes custaria entre $\$ 470$ a $\$ 2040$ por jogo. ${ }^{92}$ Sendo assim, talvez esse tipo de exigência para jogos não destinados à venda seja uma restrição indevida à liberdade de expressão, pois limita a

\footnotetext{
${ }^{91}$ KUTNER, L.; OLSON, C. K. Grand theft childhood: the surprising truth about violent video games and what parents can do. p.11.

${ }_{92}$ GRUBB, Ben. Fears smartphone game apps could get the chop in Australia. Disponível em <http://www.smh.com.au/digital-life/smartphone-apps/fears-smartphone-game-apps-could-getthe-chop-in-australia-20100817-128cr.html > Acesso em 28 de outubro de 2010.
} 
criação de jogos àqueles que têm condições financeiras para arcar com os custos.

Por outro lado, a completa falta de regulamentação faz com que os pais tenham pouco controle dos jogos que os filhos estão acessando via internet. Quanto a esse problema, a solução adotada pelo sistema europeu (PEGI) foi a criação de um "rótulo OK" para jogos de internet. Segundo informações da própria entidade:

Existem muitos websites e serviços online que contêm pequenos jogos. O rótulo OK do PEGI foi criado para cobrir este segmento, que está a crescer a um ritmo exponencial. Quando um pequeno jogo online disponível num website recebe o rótulo "PEGI OK", significa que o jogo pode ser utilizado por jogadores de todos os grupos etários, porque não apresenta qualquer conteúdo potencialmente inadequado. Para que o operador de um website ou portal de jogos possa utilizar o rótulo "PEGI OK", deverá apresentar uma declaração ao PEGI afirmando que o jogo não apresenta qualquer conteúdo que exija uma classificação formal.

Para obter o rótulo "PEGI OK", os jogos NÃO podem conter nenhum dos seguintes elementos:

violência

actividades sexuais ou alusões sexuais

nudez

linguagem inapropriada

apostas

promoção ou consumo de drogas

promoção de álcool ou tabaco

cenas de medo

Se o jogo contiver qualquer destes elementos, deverá ser classificado de acordo com o sistema de classificação PEGI. O jogo receberá uma classificação PEGI padrão $(4,6,12,16$ ou 18), que consiste na atribuição de um rótulo de classificação etária e de descritor(es) de conteúdo. O mesmo se aplica no caso dos jogos ocasionais que podem ser descarregados para os computadores domésticos ou no caso dos jogos que só podem ser jogados mediante pagamento de uma taxa. $^{93}$

De todo modo, enquanto uma resposta definitiva não é criada, a melhor solução encontra-se na regra geral de cuidado dos pais, que devem orientar seus filhos sobre os riscos inerentes à internet, e como eles devem fazer para usufruir da ferramenta com segurança. No mais, caso algum jogo dessa natureza seja reputado ofensivo, nos parece que o magistrado terá

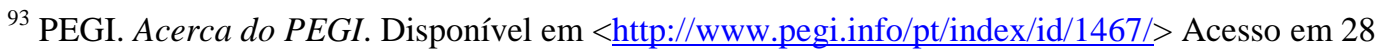
de outubro de 2010.
} 
que, efetivamente, fazer uma ponderação entre os valores em conflito, frente à falta de um meio menos restritivo para se alcançar o fim almejado. Dentro dessa lógica, tais jogos devem ser tratados como uma forma de expressão como tantas outras, e, portanto, passível de condenação posterior pelos excessos cometidos.

Ademais, por incrível que pareça, a própria necessidade da Classificação Indicativa é responsável por limitar a oferta de jogos eletrônicos no mercado brasileiro. É o que ocorre, por exemplo, com os jogos para os aparelhos Iphone, Ipod e Ipad no Brasil. Conforme destaca Claudio Prandoni:

Por causa de um conflito entre a Apple e o Ministério da Justiça, os proprietários de iPhone, iPod ou iPad no Brasil não conseguem adquirir games na App Store. Como não existe uma área de jogos na loja on-line, o jogador se vê reduzido a duas opções: limitar-se aos poucos games listados em outras categorias, como Entretenimento e Educação, ou apelar para métodos ilegais.

Normalmente, em países onde o iPhone, iPod e iPad estão oficialmente disponíveis, é a Apple quem define a classificação etária dos jogos da App Store. No Brasil, contudo, o Ministério da Justiça centraliza o processo, avaliando e indicando as idades apropriadas para produtos como novelas, filmes e também jogos eletrônicos.

O Ministério diz que "por procedimento, qualquer empresa que deseja comercializar no mercado brasileiro produtos dessa natureza, deve enviar previamente o material para análise e atribuição da Classificação Indicativa, conforme o procedimento descrito na Portaria $\mathrm{n}^{\circ} 1.100 / 06$, o que inclui também jogos para iPhone e iPod". A Apple, por sua vez, se limita a dizer que "respeita a legislação brasileira", sem entrar em mais detalhes sobre o assunto. A classificação feita pela empresa não é aceita no Brasil porque a avaliação do Ministério da Justiça é obrigatória. O mesmo acontece na China e Coreia do Sul, onde o resultado é o mesmo: nada de seção de games nas respectivas App Store locais. $^{94}$

Assim, percebe-se que a Classificação Indicativa, tal como se encontra hoje, ainda não é uma solução perfeita para todos os problemas da liberdade de expressão nos jogos eletrônicos. Nada obstante, até que sejam feitas as devidas correções, ela é a melhor - e a mais democrática alternativa que possuímos.

\footnotetext{
${ }^{94}$ PRANDONI, Cláudio. Confusão entre Apple e Ministério da Justiça impede seção de jogos na App Store brasileira. Disponível em $<$ http://jogos.uol.com.br/ultnot/multi/2010/08/31/ult530u8134.jhtm> Acesso em 28 de outubro de 2010.
} 


\subsection{Enfrentando os casos difíceis}

Assumindo que a Classificação Indicativa seja, de fato, a melhor saída para o problema proposto, ainda assim teremos perguntas que ficarão sem respostas. Será que os jogos controversos, mesmo sendo classificados para maiores de 18 anos, podem ser comercializados e reconhecidos como produtos legítimos? Podem os jogos eletrônicos retratar eventos reais, ainda que sejam episódios trágicos? É razoável que haja algum limite de conteúdo para os jogos eletrônicos? Esses são alguns exemplos de questões que precisam ser enfrentadas invariavelmente, mesmo com a existência da Classificação Indicativa. Assim, delimitar a abrangência da liberdade de expressão nos jogos eletrônicos se mostra um dever de magistrados e acadêmicos, de modo que se garanta a segurança jurídica na matéria. Dessa forma, é válido tecer algumas considerações sobre duas categorias de casos difíceis: a dos Grandes Ofensores ${ }^{95}$ e a dos jogos baseados em fatos reais.

\subsubsection{Os Grandes Ofensores}

$\mathrm{Na}$ primeira categoria encontram-se jogos tão controversos e extremados que conseguem liberar um pandemônio em escala global, ensejando discussões e proibições em muitos países. Entre os clássicos, destacam-se: Mortal Kombat, Carmaggedon, Grande Theft Auto e Postal. Essa lista, entretanto, não para por aí. De tempos em tempos, jogos com esse tipo de conteúdo são lançados no mercado (propositalmente ou não) e reacendem a polêmica até hoje não resolvida. Nessa perspectiva, dois títulos têm gerado muita discussão nos últimos anos: Manhunt e Rapelay.

Desenvolvido pela polêmica empresa Rockstar, Manhunt é certamente um dos jogos violentos mais controversos que já existiu. Banido em diversos países (mas não no Brasil), o jogo estimula o jogador a matar os adversários das formas mais cruéis possíveis, incluindo sufocamentos

\footnotetext{
${ }^{95}$ Classificação utilizada por Lauren Gonzales na obra "When two tribes go to war: a history of video game controversy.", mencionada à pagina 14 .
} 
com saco plástico, fraturas cranianas por golpes de martelo, desmembramentos por serra elétrica e decapitações. Devido ao alto grau de cenas violentas, de forma explícita e contínua, e a premiação pelos crimes praticados, diversos governos determinaram que essa obra teria cruzado os limites da liberdade de expressão. Isso não foi obstáculo, contudo, para o desenvolvimento da sua sequência, Manhunt 2, que também foi alvo de proibições em diversos países.

Já Rapelay trata-se de um simulador erótico lançado em 2006, no Japão, pela empresa Illusion. O jogo começa contando a história de um personagem que tem como hábito abusar de mulheres e que, após a denúncia de uma das vítimas, acaba indo para a cadeia. Ao sair da prisão, o protagonista, então, decide se vingar da vítima que o denunciou, estuprando não apenas ela, mas sua mãe e sua irmã menor de idade. Apesar de ter sido um lançamento destinado exclusivamente para o Japão, a internet fez com que o jogo se espalhasse pelo mundo, que recebeu com repulsa essa obra de teor sexista, ofensivo e grotesco. Devido ao grande número de protestos mundo a fora, e ao fato de que Rapelay poderia botar em risco a indústria dos jogos eróticos do Japão, a empresa Illusion retirou o jogo de produção e comercialização em $2009^{96}$. A medida, entretanto, é meramente paliativa, já que, na prática, o jogo continua circulando na internet por vias transversas.

O que Rapelay e Manhunt têm em comum? Um fascínio pelo grotesco, pelo chocante, pelo polêmico. Poucos são aqueles que ousam defender esse tipo de obra, ao dizer que são apenas formas de "escapismo", ou seja, simulações virtuais de infrações às regras que nunca poderiam ser violadas no plano real. De acordo com Lucy Kibble, uma jogadora de Rapelay, "você não precisa se sentir culpado, porque as coisas que você faz no jogo são aquelas que você nunca poderia fazer na vida real. É

\footnotetext{
${ }^{96}$ ALL ABOUT THE GAMES. Rapelay pulled from production. Disponível em $<$ http://www.allaboutthegames.co.uk/feature story.php?headline=Rapelay-pulled-fromproduction-News\&article_id=9146> Acesso em 28 de outubro de 2010.
} 
escapismo. Essa é a razão pela qual as pessoas o jogam". ${ }^{97}$ Dentro dessa lógica, se as representações virtuais de mortes ou abusos sexuais forem consideradas lazeres que não afetam terceiros, não haveria motivos para o Estado intervir no âmbito privado do indivíduo. Em outras palavras, na ausência de dano à sociedade, o que o indivíduo faz na sua esfera privada não concerne ao Estado ${ }^{98}$. Frente à falta de nocividade para a coletividade, os problemas constatados devem ser tratados pela Psicologia, e não pelo Direito.

Há, no entanto, quem entenda de maneira diversa. Para muitos, é fundamental que haja um limite de conteúdo nos jogos eletrônicos, mesmo naqueles classificados para maiores de idade - como é o caso de Rapelay e Manhunt. A grande dificuldade dessa corrente, no entanto, é definir até onde um jogo é considerado aceitável, sem cair num casuísmo perigoso à liberdade de expressão e à segurança jurídica.

Nesse tocante, vale lembrar que o jogo Rapelay já foi objeto de investigação pelo Grupo de Repressão a Crimes Cibernéticos do Ministério Público Federal. No entanto, de acordo com o procurador da República Sérgio Suiana, a legislação brasileira não tipifica o abuso sexual simulado de crianças, adolescentes e adultos, o que impede o combate ao título. Segundo ele:

É um absurdo um jogo em que o objetivo seja um estupro, mas infelizmente não há preceitos legais para analisarmos o caso. Ele faz parte de uma grande discussão jurídica sobre até onde vai a liberdade de expressão e onde começa o crime. $^{99}$

Pelo que se percebe, mesmo que adotemos a Classificação Indicativa como alternativa às proibições, ainda existe muito a se discutir quanto ao

\footnotetext{
${ }^{97}$ CNN. Should video games be restricted? Disponível em $\langle$ http://connecttheworld.blogs.cnn.com/2010/03/30/when-does-a-video-game-go-too-far/> Acesso em 28 de outubro de 2010.

${ }^{98}$ De acordo com Nelson Rodrigues, em uma de suas célebres frases: "Se todos conhecessem a intimidade sexual uns dos outros, ninguém cumprimentaria ninguém."

${ }^{99}$ DI FRANCO, Carlos Alberto. Game premia estupro e pedofilia. Disponível em <http://www.estadao.com.br/estadaodehoje/20090406/not imp350582,0.php> Acesso em 28 de outubro de 2010.
} 
conteúdo dos jogos eletrônicos. Ainda que não tenhamos a pretensão de resolver esse duelo de forças em tão poucas linhas, vale destacar três lições do direito constitucional americano que, por certo, teriam utilidade nessa celeuma. São elas:

De fato, pensamos que é justamente porque os agentes do governo não podem estabelecer distinções principiológicas nessa área [da livre expressão] que a Constituição deixa questões relativas a gosto e estilo estritamente ao indivíduo. Cohen v. California ${ }^{100}$

O fato da sociedade considerar a expressão ofensiva não é razão suficiente para suprimi-la. De fato, se é a opinião do emissor que provoca a ofensa, essa conseqüência é a razão para atribuí-la a proteção constitucional. Isso porque é um princípio central da Primeira Emenda que o governo deve permanecer neutro no mercado de idéias. - FCC v. Pacifica Foundation ${ }^{101}$

Acredito ser aconselhável adotarmos como máxima o que há muito tempo já faz parte da sabedoria da humanidade: De gustibus non est disputandum. Assim como não se discute sobre gosto, não se deveria litigar por ele. Isso porque decidir "o que é beleza" seria uma inovação para os tribunais, até mesmo para os padrões de hoje. - Pope v. Illinois ${ }^{102}$

Assim, a liberdade de expressão deve ser vista como uma garantia constitucional que permite ao indivíduo externar visões que não necessariamente são partilhadas pela vasta maioria dos seus pares. Com efeito, tal direito visa assegurar a participação de todas as formas de expressões, sejam elas de mau gosto ou não. Filtrar e refutar as mensagens consideradas inadequadas, por essa ótica, é um dever da sociedade, destinatária das mensagens, e não do Estado. Ao entendermos de maneira diversa, de que cabe ao Estado definir o que é, ou não, de bom gosto para todos, abre-se um precedente perigoso que põe em xeque a própria noção de autonomia do indivíduo.

\footnotetext{
${ }^{100}$ Cohen v. California. 403 U.S. 15, 91 S.Ct. 1780, 29 L.Ed.2d (1971). Disponível em $\langle$ http://caselaw.lp.findlaw.com/scripts/getcase.pl?court=us\&vol=403\&invol=15 $>$ Acesso em $28 \mathrm{de}$ outubro de 2010

${ }^{101}$ FCC v Pacifica Foundation. 438 U.S. 726 (1978). Disponível em $\langle$ http://caselaw.lp.findlaw.com/scripts/getcase.pl?court=US\&vol=438\&invol=726 $>$. Acesso em 28 de outubro de 2010.

${ }^{102}$ Pope v. Illinois, 481 U.S. 497 (1987) Disponível em <http://supreme.justia.com/us/481/497/case.html> Acesso em 28 de outubro de 2010.
} 
Ao mesmo tempo, é interessante que se permita a emersão desses conteúdos considerados inadequados, de modo que o debate expurgue as verdadeiras raízes dos problemas. Do mesmo modo, essa postura impede a proliferação dos jogos criados pura e exclusivamente para sobreviver de polêmicas. É o que Kutner e Olson revelam na seguinte passagem:

\begin{abstract}
O conteúdo de alguns dos jogos disponíveis para as crianças deve provavelmente gerar reflexão até mesmo dos mais ardentes defensores da liberdade de expressão. Como gerações anteriores de críticos de mídia e reformadores sociais, descritos no capítulo 2, é tentador para os pais e políticos se concentrarem em exemplos raros e extremos de jogos problemáticos, como alguns dos jogos de recrutamento neonazista que iremos descrever mais adiante neste capítulo. No entanto, isso pode levar a duas consequiências negativas imprevistas para a sociedade, em geral, e para os nossos filhos, em particular.

Primeiro, essa abordagem dá a esses jogos o reconhecimento e a publicidade que os fabricantes tanto desejam, mas que de outra forma não conseguiriam. Ela os legitima e os faz parecer mais populares do que realmente são. Em segundo lugar, ela desvia o nosso foco de encontrar formas eficazes para resolver os problemas subjacentes, tais como o racismo, o sexismo, o anti-semitismo, a pobreza, as drogas e o isolamento social. É muito mais fácil culpar um jogo (ou um gibi ou um filme) do que analisar questões sociais complexas.

Além disso, ao focarmos nossa atenção sobre o conteúdo dramático e perturbador, corremos o risco de encobrir alguns problemas potencialmente mais significativos, porém muito mais sutis. Estão os jogos de videogame sendo utilizados para vender coisas insalubres ou inadequadas para os nossos filhos? Estão os jogos mudando a percepção dos nossos filhos sobre o comportamento considerado normal ou adequado e sobre relações saudáveis? ${ }^{103}$
\end{abstract}

\title{
Há de observar que semelhante preocupação já foi manifestada pelo
}

escritor belga Raoul Vaneigem, ao afirmar:

Não se combate nem se desestimula a estupidez e a ignomínia proibindo-as de se exprimir: a melhor crítica de um estado de fato deplorável consiste em criar a situação que o previna. A estupidez, a infâmia, o pensamento ignóbil são o pus de uma sensibilidade ferida. Impedi-lo de escorrer é envenenar a ferida em vez de diagnosticar suas causas para the dar remédio. Se não quisermos que uma aberração venha a infectar o tecido social como um tumor maligno, devemos reconhecê-la tal como ela é: o sintoma de uma doença no indivíduo e na sociedade.

Não é o sintoma que deve ser condenado, é nossa pouca pressa em erradicar as condições que propagam o prurido, o abscesso, a peste. Mais que cuidar de esmagar o infame, vale apoiar o desejo de viver melhor - isto é, mais humanamente.

O que a liberdade de palavra faz é exprimir para o melhor e, mais frequentemente para o pior, o que está escondido no corpo e na consciência do homem, ${ }^{103}$ KUTNER, L.; OLSON, C. K. Grand theft childhood: the surprising truth about violent video
games and what parents can do. p.140. 
desnaturado por séculos de desumanidade. Nenhuma ignomínia deve permanecer indizível, sob pena de se enraizar ainda mais em um comportamento solipsista, cujas razões ela reforça.

(...)

A infâmia que os marca encoraja-os em sua indignidade e em sua simplória nostalgia: o que mais conforta a estupidez é dar-lhe razão por meio da execração ou da polêmica. Se tantas más reputações se devem ao desprezo e ao ódio, é que existe entre censor e censurado um fascínio secreto e mútuo.

(...)

A verdade é que a violência decorre de condições bem precisas: a promiscuidade, o excesso, o gueto, a opressão, a asfixia, a couraça caracterial, o tédio, a frustração. Uma vez carregado o canhão, o menor motivo o faz disparar: jogo de futebol, videogame, sentimento de injustiça, medo visceral, receios quanto à segurança, iluminação, barulho. ${ }^{104}$

Por fim, é preciso ter em mente que a maioria dos jogos eletrônicos possui um "ciclo de vida" relativamente curto, pelo qual eles são produzidos, alcançam seu pico de popularidade e, eventualmente, são esquecidos ou substituídos por novos lançamentos. Poucas são as obras que têm força o suficiente para serem lembradas e jogadas por muitos anos, principalmente se não forem postas em evidência. Por consequência, frente à grande quantidade de lançamentos, quase que de forma contínua, existe uma seleção natural dos jogos eletrônicos, pela qual apenas os títulos inovadores e com boa qualidade técnica conseguem sobreviver para além do seu tempo.

Ao revés, quando o Estado proíbe determinado jogo eletrônico, seja ele de que qualidade for, essa obra acaba imortalizada, sendo artificialmente lembrada (e jogada) por muitas gerações como o "jogo proibido". Há, inclusive, uma grande parcela de jogadores que sequer teriam conhecimento do título se o mesmo não fosse posto sob os holofotes da imprensa ou do escrutínio judicial. Efetivamente, não há nada melhor para a venda de um jogo do que uma boa polêmica, a qual se aproveita da curiosidade humana para atrair a atenção do seu público alvo. A história já provou que essa assertiva é verdadeira, permitindo que títulos como Death Race e Custer's Revenge alcançassem popularidade em seu tempo, a despeito dos seus

\footnotetext{
${ }^{104}$ VANEIGEM, Raoul. Nada é sagrado, tudo pode ser dito: reflexões sobre a liberdade de expressão. p.32-33.
} 
péssimos gráficos e fraca jogabilidade, e fossem lembrados até hoje mesmo tendo sido lançados há mais de 30 décadas. Sendo assim, esse aspecto sociológico deve ser levado em consideração antes da proibição de qualquer obra, se o que se busca é a efetividade da medida.

\subsubsection{Jogos baseados em fatos reais}

Em seguida, cabe refletirmos se os jogos eletrônicos devem ficar restritos a temas fictícios, ou se os mesmos podem retratar fatos reais, ainda que se tratem de episódios trágicos. Inicialmente, cumpre destacar que esse cenário não é hipotético: com o amadurecimento da mídia eletrônica, é cada vez maior o número de produções que buscam debater temas mais sérios, ainda que essa iniciativa não seja bem recebida por muitos. Como exemplo, é possível citar o jogo Six Days in Fallujah, que foi abandonado pela sua produtora devido às fortes críticas e pressões da opinião pública. Desenvolvido pela empresa Atomic Games, o jogo focava na operação Iraqi Freedom, principalmente na segunda batalha de Fallujah - também conhecida como operação Phantom Fury - e tinha como intuito recriar a batalha pela perspectiva das próprias tropas americanas. A premissa do jogo, no entanto, foi sujeita a muita controvérsia, principalmente pelo fato do episódio, um dos mais sangrentos da campanha, ser ainda muito recente. Segundo Tansy Hoskins, membro do grupo de protesto Stop the War Coalition, "o massacre de Fallujah deve ser lembrado com vergonha e horror, não glamurizado e tratado como entretenimento". ${ }^{105}$ Sob forte alvo de críticas, a empresa responsável por lançar o jogo decidiu abandonar o projeto.

Ainda no gênero das campanhas militares, o novo título da série Medal of Honor já foi alvo de críticas e tentativas de proibição no Reino

\footnotetext{
${ }^{105}$ THOMSEN, Michael. Games with the Power to Offend: Surviving and Stoking Controversy. Disponível em <http://www.gamasutra.com/view/feature/6035/games_with_the_power_to_offend_php〉. Acesso em 28 de outubro de 2010.
} 
Unido. De acordo com ministro da Defesa do país, Liam Fox, Medal of Honor é uma obra de mau gosto, já que oferece ao jogador a possibilidade de ser um militante do talibã e matar soldados britânicos. Nas palavras do próprio ministro:

Estou indignado e zangado. É difícil acreditar que qualquer cidadão do nosso país queira comprar um jogo tão antibritânico. Peço aos comerciantes para que mostrem seu apoio a nossas Forças Armadas e proíbam este produto de tão mau gosto. ${ }^{106}$

Em resposta aos argumentos do ministro, o porta-voz da empresa responsável pelo jogo afirmou que "o formato do novo 'Medal of Honor' simplesmente reflete o fato de que em todo conflito existem dois lados."107 Nada obstante, a empresa acabou cedendo à pressão da opinião pública, trocando a expressão "talibã" por "opfor", um termo militar em inglês para força da oposição. ${ }^{108}$

Saindo da esfera de jogos de guerra, outra espécie que também gera bastante polêmica é aquela que retrata tragédias, tais como os tiroteios ocorridos nas escolas e universidades americanas. Quanto a esses últimos, dois jogos amadores já foram criados: Super Columbine Massacre RPG! e $V$-Tech Rampage.

Super Columbine Massacre RPG! trata-se de um jogo gratuito e disponível na internet, no qual o jogador assume o papel dos dois adolescentes responsáveis pela tragédia ocorrida em Columbine High School, em 1999. De acordo com seu criador, Danny Ledonne:

Super Columbine permite aos jogadores confrontar os últimos dias desses dois meninos profundamente incompreendidos e irritados através das suas próprias

\footnotetext{
${ }^{106}$ ESTADÃO. Reino Unido quer proibir game em que jogador pode ser do Taleban. Disponível em <http://www.estadao.com.br/noticias/internacional,reino-unido-quer-proibir-game-em-quejogador-pode-ser-do-taleban,599205,0.htm> Acesso em 28 de outubro de 2010. ${ }^{107}$ Ibid.

${ }^{108}$ Id. Game sobre guerra do Afeganistão tem opção para Taleban desabilitada. Disponível em $<$ http://www.estadao.com.br/noticias/internacional,game-sobre-guerra-do-afeganistao-tem-opcaopara-taleban-desabilitada,618481,0.htm> Acesso em 28 de outubro de 2010.
} 
escritas, seus próprios testemunhos, e dá a chance ao jogador de entender o que se passava em suas cabeças. ${ }^{109}$

Como era de se esperar, a criação de Ledonne gerou bastante controvérsia na sociedade americana. Para uns, o jogo era uma agressão à família das vítimas, transformando desnecessariamente uma tragédia em entretenimento. Outros, no entanto, parabenizaram a iniciativa do autor, que conseguiu unir a interatividade com conteúdo de documentário, criando uma verdadeira obra de arte. Nesse embate, até mesmo aqueles que foram pessoalmente afetados pelo massacre viram o jogo sobre diferentes pontos de vista. $^{110}$

$V$-Tech Rampage, por sua vez, segue a mesma fórmula do anterior, tendo como pano de fundo, no entanto, o ataque ocorrido em Virginia Tech, em 2007. Vale destacar que, a despeito dos acalorados debates, ambos os jogos continuam disponíveis na internet até a presente data.

Sobre esse jogos, alguns críticos fazem algumas considerações relevantes. David Kociemba, professor de arte da Emerson College, levanta a seguinte questão:

Por que Michael Moore pôde, em 2002, fazer "Tiros em Columbine" - um filme ensaio sobre essa matéria - e usar muito mais materiais gráficos que Danny Ledonne usou três anos depois, em um jogo de baixa resolução? Será que nós estamos realmente dizendo que os designers de video game são uma espécie de artista que não possui o direito de se engajar em questões políticas contemporâneas? ${ }^{111}$

Winda Benedetti, a seu turno, expõe que:

Desde um jogo sobre a fuga de uma criança judia de campos de concentração nazista, até jogos que tratam do abafamento de casos de pedofilia na Igreja Católica e que colocam os jogadores no papel de um terrorista que busca matar o presidente Bush, esses jogos - normalmente criados por desenvolvedores independentes que trabalham foram da indústria - perguntam questões difíceis, retratam pontos de vista perturbadores e oferecem experiências que algumas pessoas acreditam que nunca deveriam ser experimentadas.

\footnotetext{
${ }^{109}$ BENEDETTI, Winda. These games really push our buttons. Disponível em <http://www.msnbc.msn.com/id/25835616/> Acesso em 28 de outubro de 2010. ${ }^{110}$ Ibid.

${ }^{111}$ Ibid.
} 
(...)

Uma coisa é certa: à medida que os kits de desenvolvimento de jogos se tornam mais baratos para compra e os jogos se tornam mais fáceis de fazer, mais pessoas estão usando os jogos como veículos para expressar suas opiniões, suas convicções e até mesmo suas fantasias mais sombrias. Isso significa que provavelmente veremos mais jogos que nos causam desconforto...e as vezes até irritação. ${ }^{12}$

Pelo que se observa, a discussão sobre a viabilidade desse gênero de jogos ainda está em aberto, com argumentos para ambos os lados. O Brasil, por enquanto, ainda está à margem dessa problemática, uma vez que as "realidades" retratadas nesses jogos envolvem eventos estrangeiros que, via de regra, não incomodam ou interessam à sociedade brasileira. Isso porque ainda somos grandes importadores de jogos, e não produtores, o que põe os EUA e demais países europeus na vanguarda dessa discussão. No entanto, esse cenário pode vir a mudar nos próximos anos, uma vez que o Brasil já sinalizou seu interesse em participar nesse segmento: não só já temos cursos de graduação em produção de jogos, como pós-graduações e uma própria escola dedicada à formação de profissionais ligados a área de jogos - a Seven Games. ${ }^{113}$ Desse modo, antecipar essa discussão, antes mesmo da ocorrência de problemas, pode vir a ser uma boa idéia, dando tempo para uma apreciação mais criteriosa do assunto.

\footnotetext{
${ }^{112}$ Ibid.

${ }^{113}$ GOMES, Rodrigo. Comprovando tendência de crescimento da área, nova escola de games é inaugurada no Rio <http://oglobo.globo.com/educacao/mat/2010/10/20/comprovando-tendenciade-crescimento-da-area-nova-escola-de-games-inaugurada-no-rio-922827113.asp > Acesso em 28 de outubro de 2010.
} 


\section{CONCLUSÃO}

Feitas as devidas considerações, podemos agora retornar às indagações que ensejaram o início desse trabalho. Como pudemos perceber, as controvérsias ligadas ao conteúdo dos jogos eletrônicos não são um fenômeno recente, mas um problema que remonta aos primórdios da sua própria história. Mais de 30 anos já se passaram entre Death Race 2000 e Call of Duty: Modern Warfare 2, mas uma realidade continua a mesma: temas como violência, sexo, drogas e fatos reais ainda são um barril de pólvora para a opinião pública. Dentro desse contexto global de discussões sobre os limites dos jogos eletrônicos, o Brasil já teve sua parcela de participação através de medidas dos Poderes Executivo, Judiciário e Legislativo. Quanto a essas, nosso balanço atual é de 2 jogos proibidos por decisões administrativas, 10 jogos proibidos por decisões judiciais, 5 projetos de lei arquivados e mais 8 em andamento.

Em que pese a boa intenção dos julgadores e legisladores, que buscam assegurar a proteção integral de crianças e adolescentes, todas as medidas tomadas até hoje são inadequadas, tanto em sua essência, quanto em seu plano de eficácia ${ }^{114}$. A história comprova que tudo que é proibido acaba mais procurado, o que não é diferente no mundo dos jogos eletrônicos. Sendo assim, censurar um jogo é remetê-lo à periferia do direito e à clandestinidade da internet, na qual o Estado tem pouco controle e a difusão de conteúdo é quase que imediata.

Ademais, como já destacado, os jogos têm, em geral, um curto ciclo de existência. Quando proibidos, entretanto, passam a gozar de uma imortalidade artificial, que é justamente o oposto do que se espera de

\footnotetext{
${ }^{114}$ Em entrevista para o programa Fantástico, exibido na Rede Globo no dia 25 de maio de 2008, Bruno Feijó, professor de informática da PUC-RIO e da UERJ, reiterou que a proibição dos jogos não é apenas preconceituosa, mas ineficaz, "porque ela não tem meios de controlar o acesso, o uso desse conteúdo digital nas suas várias formas, não só o game”. FANTÁSTICO. Games proibidos continuam disponíveis em camelôs e lan houses. Disponível em $<$ http://fantastico.globo.com/Jornalismo/FANT/0,,MUL699252-15605,00.html > Acesso em 28 de outubro de 2010.
} 
algumas obras. Ao mesmo tempo, tentar combater jogo por jogo trata-se de uma tarefa hercúlea e infrutífera, já que o problema apresentado assemelhase a figura mitológica da Hidra de Lerna: para cada título proibido, pelo menos dois novos já tomaram o seu lugar. Assim, é mais interessante que o Estado invista em campanhas de conscientização dos pais e na fiscalização de estabelecimentos, multando aqueles que venderem ou permitirem o acesso de menores a jogos não adequados à suas faixas etárias, tal como já o faz com cigarros e bebidas alcoólicas. Para isso, basta que o Estado se valha das previsões dos arts. 256 e 258 do ECA, que estabelecem as infrações administrativas referentes ao desrespeito da Classificação Indicativa. $^{115}$

Outro ponto a ser relembrado é que todas as decisões já proferidas sobre esse tema padecem de duas premissas equivocadas, quais sejam: que os jogos eletrônicos são destinados ao público infantil e que seu uso implicaria em distorção de valores e incentivo ao crime. No que se refere à primeira, restou claro que o seu público alvo é bastante heterogêneo, sendo a idade média do jogador superior a 30 anos. Esse é, inclusive, um dos principais tabus que precisam ser vencidos pelos jogos eletrônicos, de modo a serem reconhecidos como uma mídia séria. Já quanto à segunda, ficou evidenciando que ainda não há consenso entre os pesquisadores sobre os efeitos dos jogos eletrônicos, principalmente por conta de divergências metodológicas. Nada obstante, mesmo que adotemos a posição mais conservadora, de que os jogos eletrônicos possuem, de fato, um impacto significativo na formação infanto-juvenil, o instrumento mais adequado para esse controle não é o judicial, mas sim o dos pais, de forma a preservar os direitos de terceiros que não se encaixam nessa faixa etária.

\footnotetext{
${ }^{115}$ Vide a ementa do REsp de $\mathrm{n}^{\circ}$ 861517: "2. Ao permitir que menores de 18 anos tivessem acesso aos jogos Counter Strike e GTA, o responsável pelo estabelecimento em questão deixou de observar o disposto no art. 75 da Lei $n^{\circ}$ 8.069/90, o que configura a infração administrativa descrita no art. 258 da referida norma. 3. Recurso especial parcialmente conhecido e, nesta parte, não-provido."

Superior Tribunal de Justiça, acórdão em recurso especial de no 861517/MG, Segunda Turma, Rel. Ministro Mauro Campbell Marques, publicado em 11 de março de 2009.
} 
Para tanto, entra em cena a Classificação Indicativa, mecanismo utilizado de maneira eficaz em diversos países ${ }^{116}$, o qual visa auxiliar os pais no controle de conteúdo de obras audiovisuais. Se, por um lado, o sistema da Classificação Indicativa ainda não é perfeito, devendo passar por uma série de ajustes, por outro, ele é a alternativa menos restritiva que dispomos até hoje. Dessa forma, a Classificação Indicativa pode até não ser a resposta mais popular para enfrentar os casos mais extremados, mas certamente é a mais coerente com o ordenamento jurídico vigente.

A violência é uma realidade humana. Entender porque tal tema desperta nosso interesse é algo demasiadamente complexo, que certamente ultrapassa as pretensões desse trabalho. No entanto, o que não se pode admitir é um cenário inconsistente, no qual a violência é condenada em um meio e glorificada no outro. Prova disso é o sucesso da violenta série Jogos Mortais que, além de se encontrar em seu $7^{\circ}$ episódio, conseguiu entrar no Guiness, o livro dos recordes, como a "série de maior sucesso" da história do cinema. ${ }^{117}$ Garantir a paridade de tratamento entre mídias, portanto, é um fator chave no futuro do desenvolvimento dos jogos eletrônicos.

Em meio a tantas constatações práticas e de cunho sociológico, fazse necessário ressaltar a importância da liberdade de expressão para o debate em tela. Apesar de ser o verdadeiro alicerce do raciocínio aqui construído, tal garantia constitucional ainda aparece de forma tímida na jurisprudência pátria, sendo rechaçada com facilidade quando em conflito com outros direitos fundamentais. Ocorre que a defesa da livre expressão,

\footnotetext{
${ }^{116}$ De acordo com um recente relatório elaborado pela Federal Trade Comission, agência federal americana que defende os interesses dos consumidores, a indústria dos jogos eletrônicos supera as de filmes e música nas 3 principais áreas que a Comissão tem estudado na última década: (1) restrição do marketing de produtos adultos para crianças; (2) divulgação clara e proeminente da classificação indicativa; e (3) restrição do acesso de crianças a produtos de adultos.

FEDERAL TRADE COMISSION. Marketing Violent Entertainment to Children: A sixth followup review of industry practices in the motion Picture, music recording \& electronic game industries. Disponível em <http://www.ftc.gov/os/2009/12/P994511violententertainment.pdf>. Acesso em 28 de outubro de 2010.

${ }^{117}$ O GLOBO - CULTURA. 'Jogos mortais' entra para o 'Guiness' como a franquia de filmes de terror de maior sucesso. Disponível em <http://oglobo.globo.com/cultura/mat/2010/07/27/jogosmortais-entra-para-guiness-como-franquia-de-filmes-de-terror-de-maior-sucesso-917253761.asp $>$ Acesso em 28 de outubro de 2010.
} 
tão sagrada ao Estado-democrático de direito, pressupõe a aceitação de algumas responsabilidades, entre elas a tolerância do desagradável e do mau gosto. Isso porque é da sua natureza proteger as visões minoritárias, não consensuais ou simplesmente detestáveis. Por motivos óbvios, ninguém invoca tal direito para falar o que é agradável ou compartilhado com os demais; tal não é o caso, no entanto, daqueles que desafiam a opinião pública, desbravando as últimas fronteiras da liberdade de expressão. Nas palavras de Larry Flynt, homem responsável por um dos casos mais emblemáticos sobre a liberdade de expressão nos EUA, "se a Primeira Emenda conseguir proteger um idiota como eu, ela protegerá todos vocês".

Não é dever do Estado determinar o que são, ou não, mensagens corretas, adequadas, aprazíveis. Tal tarefa incumbe precipuamente ao próprio povo, emissor e destinatário das mesmas. Conforme já salientado pelo poeta inglês John Milton, no seu famoso discurso Areopagitica, as pessoas são dotadas de razão e, portanto, da capacidade de distinguir as boas idéias das más ${ }^{118}$. Destarte, defender os jogos polêmicos pode parecer uma excrescência, mas o que se está defendendo, no fundo, é a liberdade de criação e de escolha, que são inerentes à liberdade de expressão. Não é sensato conferir ao Estado - ou a quem quer que seja - uma carta branca para a proibição do que não é agradável. A partir do momento em que legitimamos esse tipo de conduta, seja a que título for, criamos um tumor no ordenamento jurídico que passa a depender tão somente de uma justificativa idônea para existir. Por isso, não devemos delegar a função de escolha ao Estado-juiz que, ao final, não terá a capacidade de externar a visão plural da coletividade. Do mesmo modo, não devemos perder o norte que o mau gosto não pode servir de fundamento à censura, sob pena de criarmos um grande filtro judicial para toda e qualquer produção artística, cultural ou intelectual. Como afirma Vaneigem:

\footnotetext{
${ }^{118}$ MILTON, John. The Areopagitica. Disponível em <http://www.stlawrenceinstitute.org/vol14mit.html > . Acesso em 28 de outubro de 2010.
} 
Nada é sagrado. Toda pessoa tem o direito de exprimir e de professar, a título pessoal, qualquer opinião, qualquer ideologia, qualquer religião.

Nenhuma idéia é inadmissível, até mesmo a mais aberrante, até mesmo a mais odiosa.

Nenhuma idéia, nenhum propósito, nenhuma crença devem escapar à crítica, à derrisão, ao ridículo, ao humor, à paródia, à caricatura, à simulação.

(...)

Tolerar todas as idéias não é aprová-las. Tudo dizer não é tudo aceitar. Permitir a livre expressão de opiniões antidemocráticas, xenofóbicas, racistas, revisionistas, sanguinárias não implica nem estar de acordo com os seus protagonistas, nem dialogar com eles, nem conceder-lhes pela polêmica o reconhecimento que eles esperam. Combater essas idéias responde às exigências de uma consciência sensível, empenhada em erradicá-las de todos os lugares. ${ }^{119}$

Por outro lado, saber filtrar os excessos veiculados por alguns jogos é uma tarefa que exige maturidade. Consequentemente, não podemos esperar que crianças e adolescentes tenham o discernimento necessário para determinar o que é, ou não, apropriado para seu próprio consumo. Dessa feita, até que a maioridade seja atingida, cabe aos pais dirigir a criação e a educação dos filhos, através do exercício do poder familiar, o que inclui a escolha do tipo de entretenimento adequado para eles. Vale destacar que, nessa fase da vida, a participação dos pais é crucial para o pleno desenvolvimento infanto-juvenil, sem a qual a criança ou o adolescente apresentará problemas não só com os jogos, mas em outras áreas sensíveis de sua formação. Por tais razões, os jogos não podem fugir à regra geral de cuidado dos pais, devendo ser selecionados criteriosamente.

Considerando o exposto, será que o Estado, no intuito de proibir os jogos considerados inadequados, não está causando mais mal do que bem? Pelo que se percebe, a postura distante e preconceituosa de alguns julgadores é um sério obstáculo aos jogos eletrônicos, pois ceifa o imenso potencial cultural, artístico e de entretenimento apresentado por essa tecnologia ${ }^{120}$. Conforme bem destacado por Kutner e Olson ${ }^{121}$, aqueles que pretendem proibir a violência nos jogos eletrônicos muitas vezes se valem

\footnotetext{
${ }^{119}$ VANEIGEM, Raoul. Nada é sagrado, tudo pode ser dito: reflexões sobre a liberdade de expressão. p.23-25.

${ }^{120}$ Nas palavras do filósofo Blaise Pascal: "O homem esta sempre disposto a negar tudo aquilo que não compreende”

${ }^{121}$ KUTNER, L.; OLSON, C. K. Grand theft childhood: the surprising truth about violent video games and what parents can do. p.190.
} 
de um raciocínio bastante semelhante ao da "Aposta de Pascal"122: proibir é o mais inteligente a se fazer, já que as potenciais consequiências de se estar errado (ou seja, proibiu-se a venda de jogos violentos, ainda que esses não causem nenhum dano ao jogador) são mais do que compensadas pelas conseqüências de se estar certo (ou seja, reduziu-se um risco real ao proibir esses jogos, já que os mesmos induzem o jogador a um comportamento agressivo). Todavia, esse argumento falha ao ignorar que, ao se focar nos jogos eletrônicos, a sociedade e o Estado desviam a atenção de outros fatores que sabidamente estimulam a violência. Em outras palavras, acabase gastando tempo, dinheiro e energia focando nas causas erradas.

É evidente que o cenário brasileiro não é tão alarmante como o de outros países, se considerarmos que os jogos já proibidos por aqui são ultrapassados e não mais comercializados. No entanto, a simples existência de precedentes faz com que esse debate seja relevante e contemporâneo, de modo a erradicar essa ameaça ainda em seu estágio embrionário. Talvez esse seja um dos momentos mais oportunos para retomar essa discussão, tendo em vista que o Estatuto da Criança e do Adolescente acaba de completar 20 anos de existência. Ao que tudo indica, a melhor saída encontra-se em uma leitura constitucional do referido diploma, de modo a preservar tanto o direito da liberdade de expressão, quanto a proteção integral de crianças e adolescentes. Para isso, precisamos nos valer da tripla responsabilidade prevista no art. 227 da Constituição Federal, cabendo aos pais o efetivo exercício do poder-dever de educar os filhos, ao Estado fiscalizar a venda de jogos e assegurar a classificação indicativa dos mesmos, e à sociedade, representada pelas indústrias desse setor, apresentar

\footnotetext{
${ }^{122}$ No fragmento 233 da coletânea Pensées, o matemático, físico e filósofo Blaise Pascal (16231662) apresentou o que hoje se conhece como a Aposta de Pascal. Trata-se de uma proposta de decisão colocada na forma de uma aposta incontornável, isto é, da qual ninguém pode fugir. Esta aposta pode ser resumida da seguinte forma: Como alguém que escolhe ser cristão pode perder? Se, ao morrer, constatar que Deus não existe e sua fé foi em vão, não perdeu nada - pelo contrário, viveu uma vida com mais percepção de sentido e esperança do que um descrente. Se, no entanto, há um Deus e um céu e um inferno, então ganhou o céu, ao passo que um descrente perdeu tudo. Fonte: <http://www.freewebs.com/kienitz/aposta.htm>. Acesso em 28 de outubro de 2010.
} 
mecanismos que auxiliem os pais no controle de conteúdo, como tem sido feito.

Afinal, quem perde com a proibição dos jogos eletrônicos? Perde, em primeiro lugar, a liberdade de expressão, que passa a sofrer limitações dentro de uma mídia moderna, a qual ainda possui um vasto potencial a ser explorado. Perde, em segundo lugar, o público adulto, que fica impedido de ter acesso a determinados conteúdos nos jogos, mas não em outras mídias, como o cinema ou a televisão. Perdem também os pais, quando vêem esvaziados os seus poderes de escolha e decisão, ou são iludidos pelos parcos resultados trazidos pelas medidas restritivas. Perdem os filhos, que inevitavelmente vão ter acesso aos conteúdos restritos, mas desinformados e despreparados para lidar com esse tipo de informação. Perdem as produtoras, que passam a transitar pelos campos da insegurança jurídica, tendo que adaptar o conteúdo dos seus jogos à sensibilidade de diferentes mercados. Perdem aqueles que participam da cadeia econômica da venda de jogos, que passam a ser alvo do que a Suprema Corte dos Estados Unidos chama de chilling effect, tendo que selecionar os jogos que estão dispostos a comercializar, considerando o prejuízo que podem ter, caso esses sejam retirados de mercado. Por fim, sofre o Estado, como um todo, por cercear a livre iniciativa e prejudicar o desenvolvimento econômico através de medidas ineficientes e inconstitucionais. 


\section{BIBLIOGRAFIA}

1. $\quad 3^{\mathrm{a}}$ Vara Federal da Seção Judiciária de Minas Gerais, sentença em ação civil pública de nº 1999.38.00.037967-8, Juíza Cláudia Maria Resende Neves Guimarães, Minas Gerais, publicado em 10 de outubro de 2000.

2. $16^{\mathrm{a}}$ Vara Cível do Foro Central de Porto Alegre, ação coletiva de $\mathrm{n}^{\circ}$ 10800832357, Juiz Flávio Mendes Rabello, Porto Alegre, publicado em 04 de abril de 2008.

3. $17^{\mathrm{a}}$ Vara Federal da Seção Judiciária de Minas Gerais, sentença em ação civil pública de nº 2002.38.00.046529-6, Juiz Carlos Alberto Simões de Tomaz, Minas Gerais, publicado em 08 de agosto de 2007.

4. $19^{\mathrm{a}}$ Vara Federal da Seção Judiciária de Minas Gerais, sentença em ação civil pública de nº 2006.38.00.014197-6, Juiz João César Otoni de Matos, Minas Gerais, publicado em 27 de maio de 2010.

5. $22^{\mathrm{a}}$ Vara Federal da Seção Judiciária do Distrito Federal, sentença em mandado de segurança de $n^{\circ}$ 1999.34.00.006327-6, Juiz Ênio Laercio Chappuis, publicado em 29 de março de 2000.

6. ALL ABOUT THE GAMES. Rapelay pulled from production. Disponível em $<$ http://www.allaboutthegames.co.uk/feature_story.php?headline=Ra pelay-pulled-from-production-News\&article id=9146>. Acesso em 28 de outubro de 2010. 
7. ALMEIDA, Eduardo. Projeto de lei pretende proibir videogames ofensivos no país. Disponível em $<$ http://oglobo.globo.com/tecnologia/mat/2009/12/14/projeto-de-leipretende-proibir-videogames-ofensivos-no-pais-915188685.asp> Acesso em 28 de outubro de 2010.

8. American Amusement Machine Association, et al. v. Teri Kendrick, et al. 244 F.3d 572 (7th Cir. 2001), cert. denied, 534 U.S. 994 (2001). Disponível em $<$ http://www.firstamendmentcenter.org/PDF/American_Amusement _Machine_Association_v_Kendrick.pdf> Acesso em 28 de outubro de 2010.

9. ANDERSON, Craig et al. The Influence of Media Violence on Youth. Disponível em 〈http://www.psychologicalscience.org/pdf/pspi/pspi43.pdf> Acesso em 28 de outubro de 2010. p.81-110

10. . Violent Video Game Effects on Aggression, Empathy, and Prosocial Behavior in Eastern and Western Countries: A Meta-Analytic Review. Disponível em $<$ http://www.psychology.iastate.edu/faculty/caa/abstracts/20102014/10ASISBSRS.pdf >. Acesso em 28 de outubro de 2010. 23p.

11. APPIO, Eduardo. Direito das Minorias. $1^{\text {a }}$ ed.. São Paulo: Revista dos Tribunais, 2008. p.236-247

12. AURICCHIO, Jocelyn. Game de guerra bate recordes e vira fenômeno da cultura pop. Disponível em <http://www.viuisso.com.br/wp-content/uploads/2009/11/L2.jpg>. Acesso em 28 de outubro de 2010. 
13. BARROSO, Luís Roberto. Colisão entre liberdade de expressão e direitos da personalidade. Critérios de ponderação. Interpretação constitucionalmente adequada do Código Civil e da Lei de Imprensa. Disponível em <http://www.migalhas.com.br/arquivo_artigo/art 03-10-01.htm> Acesso em 28 de outubro de 2010 .

14. BENEDETTI, Winda. These games really push our buttons. Disponível em <http://www.msnbc.msn.com/id/25835616/> Acesso em 28 de outubro de 2010.

15. CARLSSON, Ulla et al. A Criança e a Violência na Mídia. Brasília: UNESCO Brasil, 1999. Disponível em 〈http://unesdoc.unesco.org/images/0013/001308/130873por.pdf> Acesso em 28 de outubro de 2010. 448p.

16. CNN. Should video games be restricted? Disponível em <http://connecttheworld.blogs.cnn.com/2010/03/30/when-does-avideo-game-go-too-far/> Acesso em 28 de outubro de 2010.

17. Cohen v. California. 403 U.S. 15, 91 S.Ct. 1780, 29 L.Ed.2d (1971). Disponível em $<$ http://caselaw.lp.findlaw.com/scripts/getcase.pl?court=us\&vol=403 \&invol=15>Acesso em 28 de outubro de 2010.

18. DI FRANCO, Carlos Alberto. Game premia estupro e pedofilia. Disponível em <http://www.estadao.com.br/estadaodehoje/20090406/not_imp35058 2,0.php> Acesso em 28 de outubro de 2010. 
19. ESTADÃO. Reino Unido quer proibir game em que jogador pode ser do Taleban. Disponível em $<$ http://www.estadao.com.br/noticias/internacional,reino-unido-querproibir-game-em-que-jogador-pode-ser-do-taleban,599205,0.htm> Acesso em 28 de outubro de 2010.

20. Reino Unido quer proibir game em que jogador pode ser do Taleban. Disponível em $<$ http://www.estadao.com.br/noticias/internacional,reino-unido-querproibir-game-em-que-jogador-pode-ser-do-taleban,599205,0.htm> Acesso em 28 de outubro de 2010.

21. FANTÁSTICO. Games proibidos continuam disponíveis em camelôs e lan houses. Disponível em $<$ http://fantastico.globo.com/Jornalismo/FANT/0,,MUL69925215605,00.html> Acesso em 28 de outubro de 2010.

22. FCC v Pacifica Foundation. 438 U.S. 726 (1978). Disponível em $<$ http://caselaw.lp.findlaw.com/scripts/getcase.pl?court=US\&vol=43 $\underline{8 \& \text { invol=726> }}$. Acesso em 28 de outubro de 2010.

23. FEDERAL TRADE COMISSION. Marketing Violent Entertainment to Children: A sixth follow-up review of industry practices in the motion Picture, music recording \& electronic game industries. Disponível em 〈http://www.ftc.gov/os/2009/12/P994511violententertainment.pdf $>$. Acesso em 28 de outubro de 2010.

24. FERREIRA, Carlos Eduardo Dias. Pesquisa afirma que jogos violentos podem ser benéficos para o raciocínio. Disponível em 
<http://www.baixakijogos.com.br/noticias/8509> Acesso em 28 de outubro de 2010.

25. FONSECA, Rodrigo. 'Tropa de elite 2' já é maior bilheteria de estréia do cinema nacional depois da Retomada. Disponível em <http://oglobo.globo.com/cultura/mat/2010/10/10/tropa-de-elite-2ja-maior-bilheteria-de-estreia-do-cinema-nacional-depois-daretomada-922759130.asp> Acesso em 28 de outubro de 2010.

26. FREEDMAN, Jonathan. Evaluating the Research on Violent Video Games. Disponível em

<http://culturalpolicy.uchicago.edu/papers/2001-videogames/freedman.html> Acesso em 28 de outubro de 2010.

27. G1 - CIÊNCIA E SAÚDE. Jogar Tetris ajuda a reduzir estresse pós-traumático, diz estudo. Disponível em <http://g1.globo.com/Noticias/Ciencia/0,,MUL946771-5603,00JOGAR+TETRIS+AJUDA+A+REDUZIR+ESTRESSE+POSTRAU

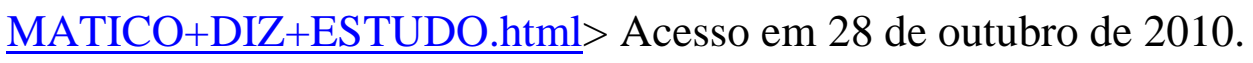

28. GOMES, Rodrigo. Comprovando tendência de crescimento da área, nova escola de games é inaugurada no Rio <http://oglobo.globo.com/educacao/mat/2010/10/20/comprovandotendencia-de-crescimento-da-area-nova-escola-de-gamesinaugurada-no-rio-922827113.asp> Acesso em 28 de outubro de 2010.

29. GONZALES, Lauren. When two tribes go to war: a history of video game controversy. Disponível em <http://www.gamespot.com/features/6090892/> Acesso em 28 de outubro de 2010.24 p. 
30. GRUBB, Ben. Fears smartphone game apps could get the chop in Australia. Disponível em <http://www.smh.com.au/digitallife/smartphone-apps/fears-smartphone-game-apps-could-get-thechop-in-australia-20100817-128cr.html> Acesso em 28 de outubro de 2010.

31. HILDEN, Julie. The Supreme Court's "Violent" Video Games Case: The California Law Should Be Struck Down, But the Court May Well Uphold It. Disponível em <http://writ.news.findlaw.com/hilden/20100510.html $>$ Acesso em 28 de outubro de 2010 .

32. HUESMANN, L. Rowell. Nailing the Coffin Shut on Doubts That Violent Video Games Stimulate Aggression: Comment on Anderson et al. (2010). Washington D.C.: Psychological Bulletin, vol. 136 (2), março de 2010. p.179-181.

33. INFO - PLANTÃO. Setor de games movimenta US\$ 60 bi por ano. Disponível em <http://info.abril.com.br/noticias/mercado/setor-degames-movimenta-us-60-bi-por-ano-15062010-15.shl> . Acesso em 28 de outubro de 2010.

34. James v. Meow Media, Inc. 300 F.3d 683, 6th Circuit Court of Appeals, 2002. Disponível em < http://caselaw.findlaw.com/us-6thcircuit/1400143.html> Acesso em 28 de outubro de 2010.

35. KOHLER, Chris. How protests against games cause them to sell more copies. Disponível em <http://www.wired.com/gamelife/2007/10/how-protests-ag/>. Acesso em 28 de outubro de 2010. 
36. KUTNER, L.; OLSON, C. K. Grand theft childhood: the surprising truth about violent video games and what parents can do. Nova Iorque: Simon \& Schuster, 2008. 260p.

37. LEMOS, Ronaldo. Games incomodam e viram arte. Disponível em <http://www.culturalivre.org.br/index.php?Itemid=40\&id=328\&opti

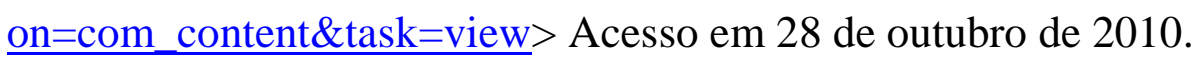

38. LIMA, Maurício; ZAKABI, Rosana. O horror fora da tela.

Disponível em < http://veja.abril.com.br/101199/p_038.html > Acesso em 28 de outubro de 2010.

39. . Penso nisso há sete anos. Disponível em <http://veja.abril.com.br/101199/p_038a.html > Acesso em 28 de outubro de 2010.

40. MACHADO, André. Jogos de guerra podem ser fonte de aprendizado, diz pesquisador. Disponível em <http://oglobo.globo.com/tecnologia/mat/2009/12/14/jogos-deguerra-podem-ser-fonte-de-aprendizado-diz-pesquisador915188696.asp > Acesso em 28 de outubro de 2010.

41. MARISCAL, Valéria Gerber. A violência nos meios de comunicação, a proteção da criança e do adolescente e o direito fundamental à liberdade de expressão. Disponível em <http://www.pucrio.br/ensinopesq/ccpg/pibic/relatorio_resumo2009/ relatorio/dir/valeria.pdf> Acesso em 28 de outubro de 2010. 19p.

42. MENDES, Gilmar et al. Curso de Direito Constitucional. São Paulo: Saraiva, 2007. 1504p. 
43. MILTON, John. The Areopagitica. Disponível em <http://www.stlawrenceinstitute.org/vol14mit.html >. Acesso em 28 de outubro de 2010.

44. MINISTÉRIO DA JUSTIÇA. Classificação Indicativa: Informação e Liberdade de Escolha. Disponível em: <http://www.abmp.org.br/UserFiles/File/cartilha_classificacao_indic ativa.pdf>. Acesso em 28 de outubro de 2010. 16p.

45. O GLOBO - CULTURA. 'Jogos mortais' entra para o 'Guiness' como a franquia de filmes de terror de maior sucesso. Disponível em <http://oglobo.globo.com/cultura/mat/2010/07/27/jogos-mortaisentra-para-guiness-como-franquia-de-filmes-de-terror-de-maiorsucesso-917253761.asp> Acesso em 28 de outubro de 2010.

46. O GLOBO - SAÚDE. Videogames podem ajudar a proteger o cérebro do envelhecimento precoce, indica estudo. Disponível em <http://oglobo.globo.com/vivermelhor/mat/2008/12/22/videogamespodem-ajudar-proteger-cerebro-do-envelhecimento-precoce-indicaestudo-587508681.asp > Acesso em 28 de outubro de 2010.

47. O GLOBO - TECNOLOGIA. "Portal”, jogo da Valve, vira referência em matéria de faculdade americana. Disponível em <http://oglobo.globo.com/tecnologia/mat/2010/08/23/portal-jogo-davalve-vira-referencia-em-materia-de-faculdade-americana917455309.asp > Acesso em 28 de outubro de 2010.

48. . "StarCraft" vira tema de curso em faculdade nos EUA. Disponível em <http://oglobo.globo.com/tecnologia/mat/2010/08/25/starcraft-vira- 
tema-de-curso-em-faculdade-nos-eua-917471626.asp> Acesso em 28 de outubro de 2010.

49. . Nova leva de games de combate mira no público acima dos 30. Disponível em $<$ http://oglobo.globo.com/tecnologia/mat/2010/01/21/nova-leva-degames-de-combate-mira-no-publico-acima-dos-30-915664756.asp>. Acesso em 28 de outubro de 2010.

50. PEGI. Acerca do PEGI. Disponível em $<$ http://www.pegi.info/pt/index/id/1467/> Acesso em 28 de outubro de 2010.

51. Pope v. Illinois, 481 U.S. 497 (1987) Disponível em <http://supreme.justia.com/us/481/497/case.html> Acesso em 28 de outubro de 2010.

52. PRANDONI, Cláudio. Confusão entre Apple e Ministério da Justiça impede seção de jogos na App Store brasileira. Disponível em <http://jogos.uol.com.br/ultnot/multi/2010/08/31/ult530u8134.jhtm> Acesso em 28 de outubro de 2010

53. Projeto de lei $\mathrm{n}^{\circ} 1654 / 96$, de autoria do dept. federal Geraldo Simões, apresentado em 04 de outubro de 2000

54. Projeto de lei $\mathrm{n}^{\circ}$ 1654/96, de autoria do dept. federal Herculano Anghinetti, apresentado em 19 de março de 1996

55. Projeto de lei $\mathrm{n}^{\circ}$ 2.566/00, de autoria do dept. federal Nilson Mourão, apresentado em 14 de março de 2000. 
56. Projeto de lei $\mathrm{n}^{\circ}$ 4932/05, de autoria do dept. federal Carlos Nader, apresentado em 21 de março de 2005

57. Projeto de lei $\mathrm{n}^{\mathrm{o}} 5712 / 05$, de autoria do dept. federal Gilberto Nascimento, apresentado em 09 de agosto de 2005

58. Projeto de lei n ${ }^{\circ}$ 6868/06, de autoria da dept. federal Laura Carneiro, apresentado em 05 de abril de 2006

59. Projeto de lei $\mathrm{n}^{\mathrm{o}}$ 170/06, de autoria do senador Valdir Raupp, apresentado em 30 de maio de 2006.

60. Projeto de lei $\mathrm{n}^{\mathrm{o}} 7319 / 2010$, de autoria da dept. federal Sueli Vidigal, apresentado em 12 de maio de 2010.

61. PROTASIO, Arthur. Games e Liberdade de Expressão.

Disponível em

<http://direitorio.fgv.br/sites/direitorio.fgv.br/files/Games\%20e\%20

Liberdade\%20de\%20Expressão_Arthur\%20Protasio.pdf $>$.

Acesso em 28 de outubro de 2010. 20p.

62. . Grand Theft Auto e a Contemporaneidade.

Disponível em <http://vagrantbard.com/2010/08/16/grand-theft-autoe-a-contemporaneidade/>. Acesso em 28 de outubro de 2010.

63. REANEY, Patrícia. Videogames violentos são inofensivos para maioria das crianças. Disponível em <http://portalexame.abril.com.br/tecnologia/noticias/videogamesviolentos-sao-inofensivos-maioria-criancas-568045.html > Acesso em 28 de outubro de 2010. 
64. Secretaria de Direito Econômico, processo administrativo de $\mathrm{n}^{\circ}$ 08012.00039-4/98-74, diretor Nelson F. Lins D’Albuquerque Júnior. Brasília, 21 de maio de 1998. Disponível em $<$ http://www.mp.rs.gov.br/infancia/legislacaoc/legislacaoc/id2157.ht m>. Acesso em 28 de outubro de 2010 .

65. STERNHEIMER, Karen. Do videogames kill? Disponível em $<$ http://www.theesa.com/facts/STERNHEIMERCONTEXTSARTIC LE.pdf> Acesso em 28 de outubro de 2010. 17p.

66. Superior Tribunal de Justiça, acórdão em recurso especial de $n^{\circ}$ 1072035/RJ, Terceira Turma, Rel. Ministra Nancy Andrighi. publicado em 04 de agosto de 2009.

67. Superior Tribunal de Justiça, acórdão em recurso especial de $\mathrm{n}^{\circ}$ 636021/RJ, Terceira Turma, Rel. Ministra Nancy Andrighi. publicado em 06 de março de 2009.

68. Superior Tribunal de Justiça, acórdão em recurso especial de $\mathrm{n}^{\circ}$ 861517/MG, Segunda Turma, Rel. Ministro Mauro Campbell Marques, publicado em 11 de março de 2009.

69. TERRA. Estudo: videogame pode melhorar vida social de adolescentes. Disponível em $<$ http://noticias.terra.com.br/ciencia/noticias/0,,OI3189556EI8147,00Estudo+videogame+pode+melhorar+vida+social+de+adol escentes.html> Acesso em 28 de outubro de 2010.

70. THOMSEN, Michael. Games with the Power to Offend: Surviving and Stoking Controversy. Disponível em 
$<$ http://www.gamasutra.com/view/feature/6035/games_with_the_po wer_to offend_.php>. Acesso em 28 de outubro de 2010.

71. Tribunal Regional Federal da $1^{a}$ Região, acórdão de $\mathrm{n}^{\mathrm{o}}$ 1999.38.00.037967-8/MG, Relator Des. João Batista Moreira, publicado em 29 de outubro de 2009.

72. Tribunal Regional Federal da $1^{\mathrm{a}}$ Região, acórdão de $\mathrm{n}^{\mathrm{o}}$ 2003.30.00.002600-0, Relatora Desembargadora Selena Maria de Almeida, publicado em 30 de julho de 2010.

73. Tribunal Regional Federal da $1^{\mathrm{a}}$ Região, acórdão em mandado de segurança de nº 1999.34.00.006327-6/DF, Relator Des. João Batista Moreira, publicado em 01 de março de 2007.

74. Tribunal Regional Federal da $1^{\mathrm{a}}$ Região, acórdão em medida cautelar inominada de $\mathrm{n}^{\circ}$ 2008.01.00.010959-9, Relator convocado Juiz Rodrigo Navarro de Oliveira, publicado em 29 de junho de 2009.

75. UOL - JOGOS. A História do Videogame. Disponível em $\langle$ http://jogos.uol.com.br/reportagens/historia/1961.jhtm>. Acesso em 28 de outubro de 2010.

76. VALOR ONLINE. Brasil desperta confiança do setor de videogame. Disponível em $<$ http://200.198.118.131/clipping/Arquivo/2010/Mar\%C3\%A7o/247 38.pdf $>$. Acesso em 28 de outubro de 2010.

77. Video Software Dealers Association v. Schwarzenegger, 556 F. 3d 950 - Court of Appeals, 9th Circuit 2009. Disponível em 
<http://www.ca9.uscourts.gov/datastore/opinions/2009/02/20/07166

20.pdf> Acesso em 28 de outubro de 2010.

78. WIKIPEDIA. History of video games. Disponível em

$\langle$ http://en.wikipedia.org/wiki/History of video_games $>$. Acesso em 28 de outubro de 2010.

79. List of banned videogames. Disponível em <http://en.wikipedia.org/wiki/List_of_banned_video_games $>$. Acesso em 28 de outubro de 2010.

80. XBOX - BRASIL. Apresentando Kinect para Xbox 360. Disponível

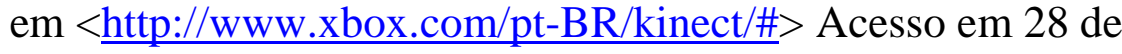
outubro de 2010.

81. ZEROZEN, Games \& Violência. Disponível em $<$ http://www.zerozen.com.br/games/games\&violencia.htm> Acesso em 28 de outubro de 2010. 